\title{
DESEMPENHO DE UM SISTEMA PIVÔ CENTRAL COM DIFERENTES CONFIGURAÇÕES DE EMISSORES, AO LONGO DO CICLO DE UMA CULTURADE MILHO (Zea mays L.)
}

\author{
PAULO CÉSAR SILVEIRA PESSOA \\ Engenheiro Agrônomo
}

Orientador : Prof. Dr. MARCOS VINÍCIUS FOLEGATTI

Dissertação apresentada à Escola Superior de Agricultura Luíz de Queiroz, da Universidade de São Paulo, para obtenção do título de Mestre em Agronomia, Área de Concentração : Irrigação e Drenagem

PIRACICABA

Estado de São Paulo - Brasil

AGOSTO - 1994 
Ficta catalografica preparada pela Secto de Livros da Divisádo de Bitioteca e Documentacao - FCLR/USF

Fessoa, Faulo Cesar Silveira

Fatsd Desempentio de un sistema piva centrel cum diferentes configuraçôs de emissores, ao longo do ciclo de uma cultura de milto (zea mays L.). Firacicabe, 1794 . P.F.

Dise. (Mestre) - ESALQ

Eibliggrafia.

1. Irrigaça por fivo central - Desempento 2. Miltio Irrigasáo I. Escola Superiar de Agricultura Luiz de Rueiroz, Firacicaba.

$$
\begin{aligned}
& \text { CDD } \quad 6.17 \\
& \text { 6SE.15 }
\end{aligned}
$$




\section{DESEMPENHO DE UM SISTEMA PIVÔ CENTRAL COM DIFERENTES CONFIGURAÇÕES DE EMISSORES, AO LONGO DO CICLO DE UMA CULTURADE MILHO (Zea mays L.)}

Aprovada em : 07/11/1994

Comissão julgadora :

Prof. Dr. Marcos Vinícius Folegatti

ESALQ / USP

Prof. Dr. José Antônio Frizzone

ESALQ / USP

Prof. Dr. Antônio Marciano da Silva

ESAL

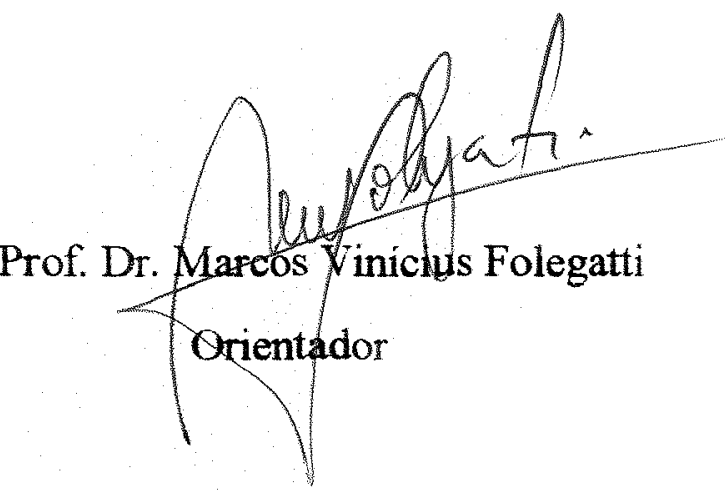


- à Deus, que iluminou meus caminhos e me fez acreditar no meu trabalho e que o esforço vale a pena,

- aos meus pais, que me apoiaram,

- aos meus irmãos e irmãs,

- aos meus sobrinhos, André e Adriana,

- à minha namorada Karla Simone,

dedico. 


\section{Agradecimentos}

- ao DER/ESALQ, pela oportunidade de realização do curso,

- ao meu orientador, Prof. Marcos Vinícius Folegatti, pela amizade, apoio, e principalmente, pela forma liberal como conduziu a orientação,

- aos professores do curso, pelos ensinamentos, dedicação e amizade,

- ao Prof. José Antônio Frizzone, pela amizade no decorrer do curso e pelas valiosas sugestões durante a execução do trabalho,

- à coordenadoria do Curso de Pós Graduação, que me deu todas as condições materiais para realização do trabalho experimental,

- à CAPES, pela concessão da bolsa de estudos,

- à todos os funcionários do DER, pela amizade e acolhida (Hélio, Gilmar, Márcio, Renato, Zezinho, Roberta Helena e Marinez),

- aos que me auxiliaram na execução do trabalho de campo (fucionários Gilmar, Renato, Márcio e colegas Fernando e Selma ), sem a ajuda dos quais seria impossível a realização deste,

- aos colegas de curso, pela convivência e amizade,

- à todas as pessoas com quem convivi durante a realização do curso e que me transmitiram coisas boas,

- às empresas CARBORUNDUM e FABRIMAR, pela doação de material utilizado no trabalho,

- à todos que, direta ou indiretamente, contribuiram para a realização deste trabalho. 


\section{SUMÁRIO}

Página

LISTA DE FIGURAS

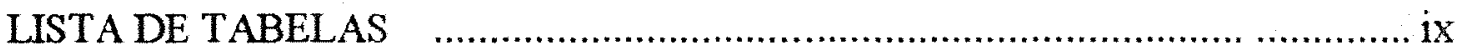

RESUMO

SUMMARY

1 INTRODUÇÃO

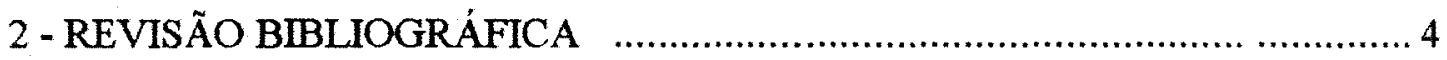

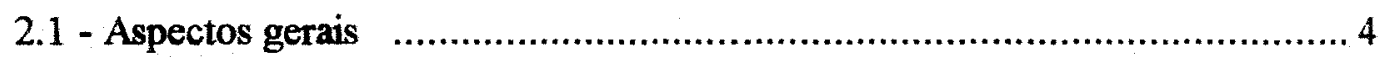

2.2 - Projeto do pivô central ……................................................................. 5

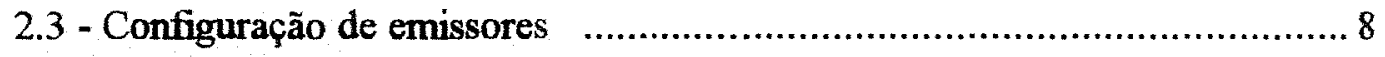

2.4 - Utilização de energia ……................................................................. 12

2.5 - Uniformidade de aplicação de água

2.6 - Desempenho do equipamento ……………….................................. 15

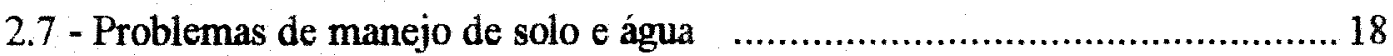

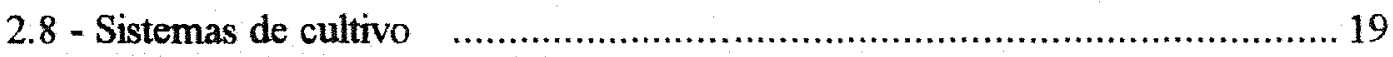

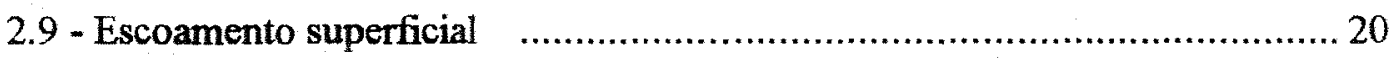

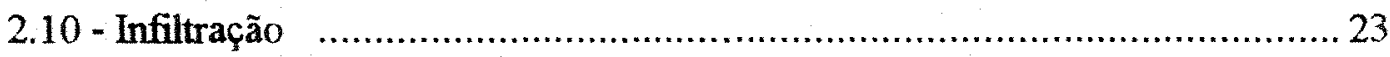

2.11 - Presença do dossel vegetativo ……..................................................... 26

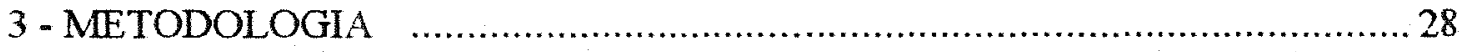

3.1 - Caracterização da área e do sistema pivó central ……………………..... 28

3.2 - Dispositivos de coleta de lâmina aplicada e escoamento 


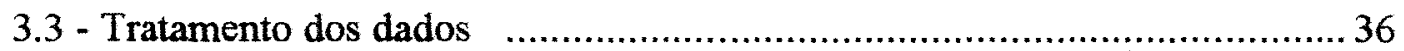

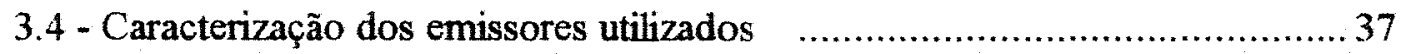

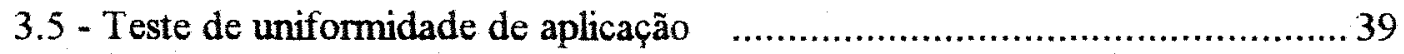

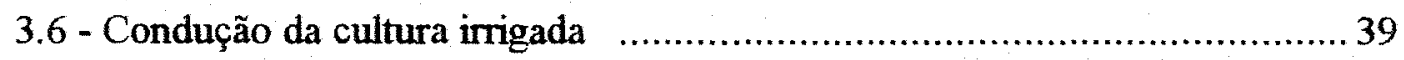

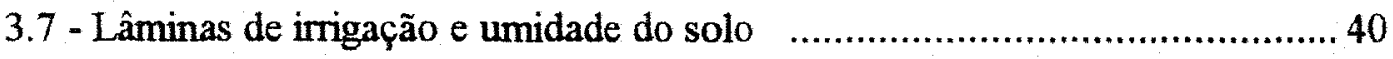

3.8 - Execução dos ensaios de campo f............................................. 40

3.9 - Determinação da curva de infiltração de água no solo $\quad$..........................42

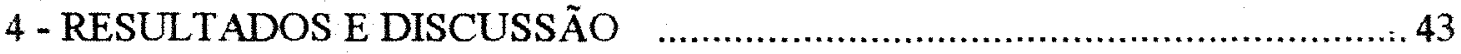

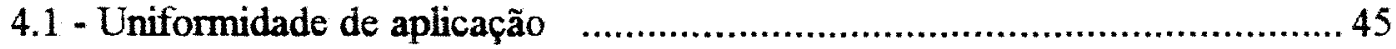

4.2 - Taxa de aplicação e escoamento ao longo do ciclo

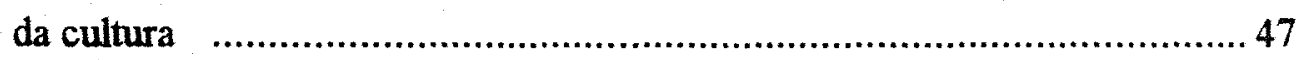

4.3 - Lâminas de aplicação, escoamento e retenção foliar .............................. 57

4.4 - Determinação da curva de infiltração de água no solo ............................ 64

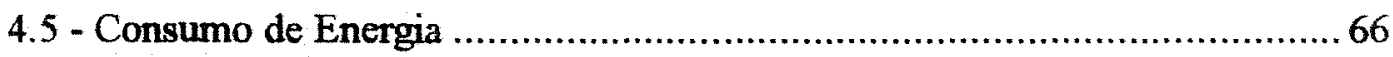

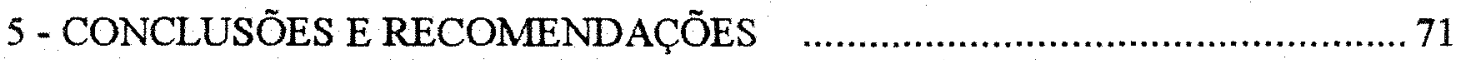

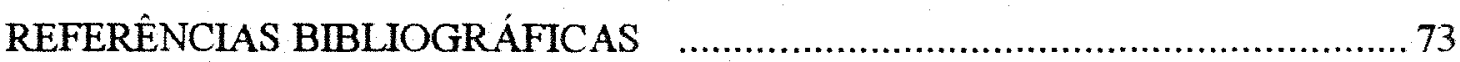

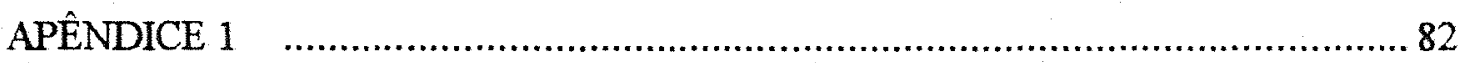

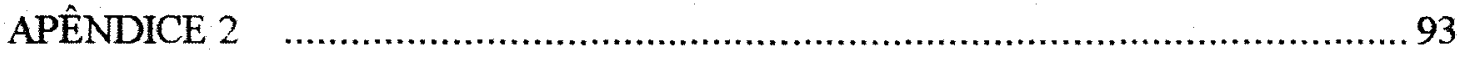




\section{LISTA DE FIGURAS}

Figura 01 - "Lay out" da localização da área experimental $\quad$............................... 30

Figura 02 - Curva de retenção de água do solo da área experimental ................30

Figura 03 - Esquema construtivo das calhas coletoras de escoamento ............... 32

Figura 04 - Esquema da instalação das calhas no campo e disposição

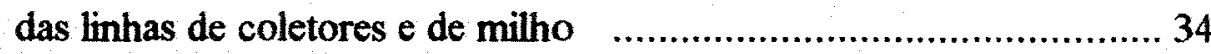

Figura 05 - Esquema da disposição das linhas de coletores em relação às linhas de plantio do milho ..................................................... 35

Figura 06 - Padrão molhado e diâmetro de alcance em função do tipo de emissor e de montagem

Figura 07 - Perfil de distribuição de água do pivô simulado 47

Figura 08 - Exemplos de curvas de valores acumulados de aplicação e escoamento, antes e após a utilização da média móvel

Figura 09 - Taxa e tempo de aplicação teóricos, segundo a equação (1), em função da lâmina aplicada e emissor utilizado

Figura 10 - Curvas de taxa de aplicação e de escoamento para milho $1 \mathrm{e}$ lâmina $6 \mathrm{~mm}$ 
Figura 11 - Curvas de taxa de aplicação e de escoamento para milho $1 \mathrm{e}$ lâmina $25 \mathrm{~mm}$

Figura 12 - Curvas de taxa de aplicação e de escoamento para milho 2 e lâmina $6 \mathrm{~mm}$ 53

Figura 13 - Curvas de taxa de aplicação e de escoamento para milho 2 e lâmina $25 \mathrm{~mm}$

Figura 14 - Curvas de taxa de aplicação e de escoamento para milho 3 e lâmina $6 \mathrm{~mm}$

Figura 15 - Taxas de aplicação média e máxima determinadas nos ensaios

Figura 16 - Valores de escoamento determinados nos ensaios 60

Figura 17 - Valores de retenção foliar determinas nos ensaios 61

Figura 18 - Perdas somadas de escoamento e retenção foliar determinadas nos ensaios

Figura 19- Curvas de aplicação e escoamento acumulados dos testes de infiltração, antes a pós a aplicação da média móvel

Figura 20 - Curvas de taxa de aplicação, escoamento e infiltração, em função da umidade do solo 66

Figura 21 - Necessidade de pressão relativa utilizando os emissores de baixa pressão e variando a declividade do terreno 


\section{LISTA DE TABELAS}

Página

Tabela 01 - Tempo de aplicação de água para diferentes posiçóes ao longo da lateral, configurações de emissores e velocidades de rotação de um pivô central ............................................................ 8

Tabela 02 - Faixas normais de pressão de operação e diâmetro de alcance associado para diferentes configurações de emissores mais utilizadas em pivô central …..................................................... 11

Tabela 03 - Pressão de operação no ponto do pivô e taxa máxima de aplicação para cinco tipos de emissores utilizados em pivô central

Tabela 04 - Posição em relação ao centro do pivô, vazão requerida e diâmetro dos bocais utilizados na simulação do pivô de 500 $\mathrm{m}$ de raio, na extremidade da lateral

Tabela 05 - Valores de lâmina d'água acumulados durante a execução do experimento, preveniente de chuva (C) ou irrigação (I)

Tabela 06 - Valores de intervalos de tempo utilizados nos ensaios, em função do emissor e lâmina aplicada 44

Tabela 07 - Caracterização das plantas de milho na data dos ensaios 45

Tabela 08 - Resultados do ensaio de uniformidade do pivô simulado, utilizando as três configurações de emissores

Tabela 09 - Dados de lâminas de aplicação, escoamento e retenção foliar obtidos nos ensaios 


\title{
DESEMPENHO DE UM SISTEMA PIVÔ CENTRAL COM DIFERENTES CONFIGURAÇÕES DE EMISSORES AO LONGO DO CICLO DE UMA CULTURA DE MLLHO (Zea mays, L.)
}

\author{
Autor : PAULO CÉSAR SILVEIRA PESSOA \\ Orientador : PROF. Dr. MARCOS VINICIUS FOLEGATTI
}

\section{RESUMO}

A seleção da configuração de emissores é a principal variável do projetista no dimensionamento de um sistema pivô central. A utilização de emissores de baixa pressão tem potencial para economizar energia, mas tende a agravar os problemas de manejo de água e solo, que podem anular os beneficios da economia energética. A presença da cultura e a dinâmica do meio agrícola são fatores que devem ser considerados num estudo da performance de um sistema de irrigação.

Estudou-se o desempenho de um sistema pivô central de $166 \mathrm{~m}$ de raio, modificado na extremidade da lateral para simular um equipamento de $500 \mathrm{~m}$, em três tipos de configuração de emissores (aspersor de impacto de média pressão, sprays fixo de baixa pressão em pendural e spray rotativo de baixa pressão) em três fases do ciclo da cultura de milho (Zea mays, L.): estabelecimento, vegetação e granação, utilizando duas lâminas por irrigação ( 25 e $6 \mathrm{~mm}$ ). Os aspectos abordados foram o escoamento superficial, taxa de aplicação, consumo de energia, eficiência e uniformidade de aplicação. Foi desenvolvida uma metodologia para estimativa da curva de infiltração de água no solo sob irrigação de pivô central baseada na determinação da taxa de aplicação e de escoamento.

Os resultados mostram que o escoamento e a taxa de aplicação aumentaram com a utilização de emissores de baixa pressão, sendo maiores para o spray 
fixo. O escoamento superficial, o perfil da taxa de aplicação e a eficiência de aplicação dos emissores foram alterados pela presença do dossel vegetativo. A retenção foliar variou para cada emissor e pode ser significativa quando se utilizam lâminas pequenas por irrigação. Estes resultados mostram que a presença da cultura deve ser considerada no desempenho do sistema de irrigação. A redução do consumo de energia pela utilização de emissores de baixa pressão pode pode chegar a $19 \%$ e será mais significativa quanto maior a relação entre a pressão no ponto do pivô e a altura manométrica total. Os emissores de baixa pressão conseguiram uniformidade comparável ou superior aos de média pressão. 


\title{
PERFORMANCE OF A CENTER PIVOT USING DIFFERENT SPRINKLER PACKAGES ON CORN CROP (Zea mays L.)
}

\author{
Author : PAULO CESAR SILVEIRA PESSOA \\ Adviser : PROF. Dr. MARCOS VINICIUS FOLEGATTI
}

\section{SUMMARY}

The sprinkler package selection is the main variable on center pivot systems design. The low pressure spray nozzles have proven to be most cost effective, but on the other hand the problem with water management can annul the benefit of saving energy. The dynamics of the irrigated crop, irrigation system and the soil have to be considered on irrigation system performance studies.

In this work was studied the performance of a center pivot of $166 \mathrm{~m}$ lenght, simulating a $500 \mathrm{~m}$ length center pivot. Three different sprinkler packages were used : medium pressure impact sprinklers, low pressure fixed sprays on drop tubes and the low pressure rotator sprays, during the corn crop development (emergence, effective full cover and maturation). The water depth of 25 and $6 \mathrm{~mm}$ were used. The main subjects studied were run off, application rate, energy imput and eficiency and uniformity application. It was developed a metodology to measure the water infiltration rate in the soil irrigated by the center pivot, considering the application and runoff rate .

The run off and application rate increased with low pressure sprays and was higher when fixed sprays were used. The crop canopy affected the run off and the water application rate. The crop leaves retention varied for each sprinkler package and was higher for low water depth applied. Considering the results it is possible to conclude that the plant canopy has to be considered on irrigation system performance studies. The energy saved by low pressure sprinkler package can be $19 \%$ and wil be higher as the 
relation of the pivot pressure and pressure head increases. Uniformity coefficient obtained with low pressure packages were comparable or higher than the medium pressure package. 


\section{1 - INTRODUÇÃO}

O principal desafio da engenharia de irrigação é desenvolver técnicas e métodos para efetivar práticas que ao mesmo tempo, aumentem a produtividade, preservem o meio ambiente e economizem energia.

A invenção e o aperfeiçoamento do sistema pivô central foi um significativo avanço da agricultura irrigada no século $\mathrm{XX}$. O equipamento teve grande aceitação pelos agricultores, devido ao seu alto padrão de desempenho e facilidade de operação. Entretanto, um equipamento de irrigação, mesmo sofisticado, só terá um desempenho satisfatório se estiver adequadamente dimensionado e manejado para as condições da área onde está operando.

No Brasil, na maioria das vezes, estes equipamentos são dimensionados sem se levar em conta as características do meio agrícola onde serão instalados, uma vez que, por se tratar de tecnologia importada, são comercializados como "pacotes fechados" pelas indústrias nacionais, sem os devidos ajustes ao local onde irão operar.

A principal variável que o projetista dispõe no dimensionamento do equipamento é a configuração de emissores (tipo, espaçamento, diâmetro de bocais e montagem), devendo fazer uma adequada combinação de parâmetros para que o pivô central tenha um desempenho satisfatório e preencha as expectativas do agricultor quando compra um equipamento sofisticado e caro. 
Os objetivos da adequada seleção da configuração de emissores e o manejo correto do equipamento são conseguir uma boa uniformidade da irrigação, reduzir as perdas de água (escoamento superficial, deriva pelo vento, evaporação), aumentar a produtividade das culturas irrigadas, economizar energia, preservar o solo e o meio ambiente.

Devido à escassez e rápida elevação de custos da energia, procura-se racionalizar o seu uso em todas as atividades produtivas, principalmente naquelas onde ela representa uma parcela significativa do custo total da produção, como é o caso da irrigação. Nesta atividade, o consumo de energia está diretamente relacionado à pressão de operação dos equipamentos. Reduzir a necessidade de energia para pressurizar os sistemas de irrigação pivô central, e ao mesmo tempo, manter a eficiência e uniformidade de aplicação é de grande interesse para a agricultura irrigada.

O desenvolvimento de emissores de baixa pressão e sua utilização em sistemas pivô central provocaram mudanças nestes equipamentos. A principal vantagem destes dispositivos consiste no potencial para economizar energia, através da redução da pressão necessária no ponto do pivô. Entretanto, sua utiłização tende a agravar problemas de manejo de solo e água, como aumento do escoamento superficial e das perdas pelo vento e por evaporação e redução da uniformidade, que muitas vezes podem anular os benefícios da economia energética.

No estudo do desempenho de um sistema pivô central, a presença da cultura e a dinâmica do meio agrícola devem ser consideradas, porque a condição de solo nu ocorre apenas nas irrigações iniciais e o grau de cobertura vegetal, condições do solo e características da planta variam ao longo do ciclo de uma cultura irrigada.

A capacidade de infiltração do solo é um importante parâmetro no projeto e manejo de um sistema pivô central. Para uma estimativa confiável, deve-se utilizar uma metodologia que represente as condições de irrigação típicas deste equipamento, ou seja, 
taxa de aplicação variável e selamento superficial do solo. Atualmente, não existe uma metodologia definitiva e as existentes utilizam equipamentos caros e pouco práticos.

Neste trabalho objetivou-se estudar o desempenho de um sistema pivô central equipado com diferentes configurações de emissores, durante o ciclo de uma cultura de milho conduzida segundo as práticas adotadas em sistemas de produção comerciais irrigados. Os aspectos estudados foram a ocorrência de escoamento superficial, taxa de aplicação, consumo de energia e eficiência e uniformidade de aplicação. Adicionalmente, foi desenvolvida uma metodologia que utiliza equipamentos simples para estimativa da curva de infiltração de água no solo sob irrigação de pivô central. 


\section{2 - REVISÃO BIBLIOGRÁFICA}

\section{1 - Aspectos gerais}

A mecanização das operações agrícolas, atiada ao aumento dos custos e escassez da mão de obra para deslocamento das tubulações e aspersores, resultaram no incremento da utilização de sistemas de irrigação mecanizados. Nestes sistemas, as tubulações e os aspersores permanecem continuamente conectados à adutora, enquanto realizam movimento contínuo e distribuição simultânea de água. Os três principais tịpos de aspersão mecanizada são o autopropelido, a lateral com deslocamento linear (lateral móvel) ou radial ( pivô central) .

O sistema pivô central fơ inventado no Colorado, Estados Unidos, em 1952. Seu uso expandiu-se consideravelmente naquele país nas décadas de 1960 e 1970 e posteriormente em outros paises, principalmente no Oriente Médio, Líbia, França, Hungria e Brasil. A área irrigada por este sistema no mundo, segundo KELLER \& BLIESNER (1990), ultrapassa os 8 milhões de hectares, num total aproximado de 160.000 equipamentos. No Brasil, segundo a ABIMAQ/SINDIMAQ, em 1991 existiam aproximadamente 3.800 equipamentos instalados, irrigando uma área estimada de 275.000 ha.

O pivô central constitui-se num sistema mecanizado e automatizado de imigação, sendo formado por uma linha lateral de emissores sustentada por torres 
triangulares metálicas sobre rodas, que são movimentadas por energia elétrica ou hidráulica, permitindo o movimento rotacional em torno do ponto do pivô.

Como a lateral se movimenta em círculo, é necessário que a taxa de aplicação aumente ao longo do raio, para proporcionar uma distribuição uniforme de água. Considerando-se o escoamento superficial, pode-se dizer que o pivô central é mais adaptado aos solos de infiltração média para alta. A velocidade de deslocamento pode ser ajustada dentro de certos limites, proporcionando um certo contrôle da lâmina aplicada. A principal vantagem deste sistema refere-se à economia de mão de obra na irrigação de áreas extensas, além da economia de água pela alta eficiência e uniformidade do sistema, que chegam a atingir valores superiores a $90 \%$. A principal desvantagem constitui-se no alto custo do equipamento, devido à sua sofisticação, além do fato de somente irrigar áreas circulares. Em campos retangulares, os cantos não serão utilizados, provocando uma perda de área de aproximadamente $20 \%$, exceto no sistema "comer" pivô (OLTTA, 1987).

\section{2 - Projeto do pivô central}

A variável mais importante no projeto de distribuição de água do pivô central é a configuração de emissores (tipo, espaçamento, diâmetro de bocais e montagem). O primeiro passo na seleção da configuração de emissores consiste na determinação da lâmina necessária no período de máximo consumo pela cultura; também devem ser determinados a velocidade de infiltração de água no solo, a capacidade do solo de armazenamento superficial de água, a intensidade de aplicação, o consumo de energia, as perdas pelo vento e por evaporação, a susceptibilidade do solo ao selamento superficial (USDA, 1983). 
De acordo com EVANS (1980), o principal objetivo do dimensionamento do equipamento pivô central é encontrar a mínima velocidade de rotação e a menor vazão, sem provocar escoamento superficial, e ainda satisfazer as necessidades de água das culturas a serem irrigadas.

HERMANN \& HEN (1968), seguindo as normas da ASAE, afirmam que o mínimo requerido para o projeto e instalação de um equipamento de aspersão é que a lâmina aplicada tenha distribuição uniforme e a intensidade de aplicação não cause escoamento superficial durante a operação normal do sistema.

De acordo com DILLON et al. (1972), por tradição, os sistemas de irrigação por aspersão são projetados de maneira que a intensidade de aplicação média não exceda a velocidade de infiltração básica do solo. Sistemas de aspersão móveis aplicam água numa taxa que varia no tempo e no espaço, e é geralmente muito mais alta que a dos sistemas estacionários (HERMANN \& KHOL, 1983). A extremidade da lateral de um sistema pivô central, em geral, aplica água numa taxa acima da curva de infiltração da maioria dos solos, porém apenas por um curto período de tempo, como salientam DILLON et al. (1972).

Segundo HERMANN \& HENN (1968), as características geométricas do pivô central determinam que a taxa de aplicação deve aumentar com a distância ao ponto do pivô, para se conseguir um lâmina de irrigação uniforme. Isto porque a vazão e a velocidade de deslocamento do emissor deve aumentar na mesma proporção do aumento da área irrigada.

A taxa de aplicação depende do comprimento e vazão do equipamento, raio de alcance e espaçamento dos emissores, diâmetro dos bocais e pressão de operação do sistema. Assumindo um perfil elíptico de distribuição de água pelo emissor, pode ser calculada conforme GILLEY (1984): 


$$
T A(t)=\frac{T_{m}}{t_{m}}\left(2 t t_{m}-t^{2}\right)^{1 / 2}
$$

em que:

TA (t) - taxa de aplicação em algum ponto no tempo $t(\mathrm{~mm} / \mathrm{h})$

Tm - taxa de aplicação máxima $(\mathrm{mm} / \mathrm{h})$

$t_{m}$ - tempo para ocorrer a taxa de aplicação máxima (h)

$t$ - tempo desde o começo da aplicação (h)

As taxas média e máxima em algum ponto sob a lateral podem ser calculadas conforme KELLER \& BLIESNER (1990):

$$
\begin{gathered}
T A_{m}=\frac{2 \pi r_{i}}{W e_{i}} \frac{L_{b}}{t_{r}} \\
T m=\frac{4}{\pi} T A_{m}
\end{gathered}
$$

em que :

$T A_{m}$ - taxa de aplicação média em algum ponto durante a irrigação $(\mathrm{mm} / \mathrm{h})$

$r_{i}$ - distância do ponto até o início da lateral $(\mathrm{m})$

$W_{i}$ - diâmetro de alcance do emissor utilizado (m)

$\mathrm{L}_{\mathrm{b}}$ - lâmina bruta aplicada por revolução (mm)

$t_{\mathrm{r}}$ - tempo para uma revolução (h)

DILLON et al. (1972) deservolveram um critério de projeto de sistema pivô central que considera as características de infiltração e armazenamento superficial do solo. A velocidade de deslocamento do equipamento (e portanto, lâmina aplicada) é ajustada em função do perfil elíptico de aphicação do emissor utilizado, para evitar escoamento superficial. MOHAMOUD et al. (1992) desenvolveram um critério de dimensionamento da configuração de emissores, através da determinação da pressão de operação mínima, diâmetro do bocal e diâmetro molhado do último emissor da lateral do pivô, para evitar o escoamento superficial. O critério considera modificações nas condições da superficie do solo, provocadas por sistemas de cultivo. 
De acordo com ADDINK et al. (1983), a taxa de aplicação varia ao longo da lateral, devido ao tempo em que a água é aplicada. O tipo e espaçamento de emissores, a posição na lateral e a velocidade de rotação do equipamento determinam o tempo de aplicação necessário para se conseguir uma lâmina uniforme, como mostrado na Tabela 1.

Tabela 1 - Tempo de aplicação de água para diferentes posições ao longo da lateral, configuraçōes de emissores e velocidades de rotação de um pivê central.

\begin{tabular}{|c|c|c|c|c|c|c|c|c|c|c|c|c|}
\hline \multirow{5}{*}{$\begin{array}{l}\text { Tempo de } \\
\text { Revohucio } \\
\text { (horas) }\end{array}$} & \multicolumn{12}{|c|}{ Distância no Longo da Lateral do Phô (metros) } \\
\hline & \multicolumn{3}{|c|}{50,3} & \multicolumn{3}{|c|}{100,6} & \multicolumn{3}{|c|}{201,2} & \multicolumn{3}{|c|}{402,3} \\
\hline & \multicolumn{12}{|c|}{ Diametro Molhado do Emissor (metros) } \\
\hline & $9,1^{\mathrm{a}}$ & $27,4^{\mathrm{D}}$ & $24,4^{c}$ & $9,1^{\mathrm{a}}$ & $27,4^{\circ}$ & $27,4^{c}$ & $9,1^{\mathrm{a}}$ & $27,4^{\mathrm{D}}$ & $39,6^{6}$ & $9,1^{a}$ & $27,4^{0}$ & $53,3^{\mathrm{C}}$ \\
\hline & \multicolumn{12}{|c|}{ Tempo de Aplleagãe de Água (minutos) } \\
\hline 6 & 10 & 34 & 28 & 5 & 16 & 16 & 3 & 8 & 12 & 1 & 4 & 8 \\
\hline 12 & 21 & 63 & 56 & 10 & 31 & 31 & 5 & 16 & 22 & 3 & 8 & 16 \\
\hline 24 & 42 & 125 & 111 & 21 & 63 & 63 & 10 & 31 & 45 & 5 & 16 & 30 \\
\hline 48 & 83 & 250 & 222 & 42 & 125 & 125 & 21 & 63 & 91 & 10 & 31 & 61 \\
\hline 60 & 104 & 313 & 278 & 52 & 156 & 156 & 26 & 78 & 113 & 13 & 39 & 76 \\
\hline
\end{tabular}

Fonte : ADDINK et al (1983)

a spray

b aspersor de impacto com espaçamento variável

c aspersor de impacto com espaçamento constante

\section{3 - Configuração de emissores}

Segundo KELLER \& BLIESNER (1990), a maior consideração quando se projeta a lateral de um pivô é a seleção da configuração de emissores; as principais variáveis são o tipo e o espaçamento entre emissores. As três mais típicas configurações de espaçamento utilizadas são :

- espaçamento uniforme, com vazão variável por emissor e aumentando proporcionalmente à distância do centro do pivô

- espaçamento semi uniforme. com vazão variável por emissor; os menores espaçamentos ocorrem no final da lateral. 
- espaçamento variável, com vazão constante por emissor; o espaçamento ao longo da lateral é inversamente proporcional à distância do centro do pivô.

O espaçamento semi uniforme é o mais utilizado, para evitar a necessidade de grandes bocais na extremidade final da lateral. Por facilidade de fabricação, a tubulação da lateral é feita com espaçamento constante entre saídas, e o espaçamento semi uniforme entre emissores é conseguido vedando-se algumas saídas com "plugs".

De acordo com TEIXEIRA (1992), os emissores mais comumente utilizados em equipamentos pivô central estão divididos em duas classes principais: aspersores de impacto (com pressão superior $250 \mathrm{KPa}$ ) e difusores ou "sprays" (pressão inferior a $175 \mathrm{KPa}$ ), onde a água é aspergida continuamente em todas as direções radiais. Os "sprays" podem ser fixos ou giratónios.

A elevação dos custos com o bombeamento de água para irrigação e a previsão de escassez e racionamento de energia no futuro resultaram no desenvolvimento e utilização de emissores de baixa pressão. O emprego desses equipamentos, que podem operar a pressões inferiores a $150 \mathrm{KPa}$, fez com que várias modificações nos equipamentos tipo pivô central se fizessem necessárias. A utilização destes emissores necessita em torno de $60 \%$ da energia requerida por pivôs equipados com aspersores convencionais de impacto, aplicando a mesma lâmina de água , com comparável uniformidade. Estes emissores produzem gotas consideraveimente menores que os aspersores convencionais, tendo assim uma menor energia cinética, provocando menor efeito destrutivo sobre a estrutura da superficie do solo. Por outro lado, possuem uma área molhada menor, estando associados a taxas de aplicação maiores. Por isso, a utilização desses emissores em solos com baixa capacidade de infiltração pode neutralizar a vantagem de se ter gotas menores (SILVA, 1989). 
Segundo JAMES \& BLAIR (1984), a utilização de emissores de baixa pressão e "sprays" tem resultado em severas modificações nos sistemas pivô central. A menor área molhada destes emissores requer menor espaçamento entre eles. Os "sprays" fixos podem ser montados "on top" na lateral ou em pendurais que podem ser extendidos abaixo da tubulação até poucos centímetros da cultura, para minimizar o efeito do vento. Estes pendurais devem ser montados alternadamente de cada lado da lateral, para aumentar a área molhada e diminuir a taxa de aplicação. Isto também pode ser conseguido pela montagem em "spray booms", que são tubos contendo vários "sprays" montados horizontalmente abaixo da lateral, em ângulo de $60^{\circ}$ a $70^{\circ}$ com o alinhamento da lateral, para aumentar a área molhada e a superposição. $O$ spray fixo consiste de um bocal e uma placa defletora, que distribui o jato em círculo completo ou parcial. $O$ bocal controla a vazão do spray. A placa defletora pode ter a superficie lisa ou estriada, afetando o diâmetro de gotas; a forma pode ser côncava, convexa ou plana, afetando o alcance de gotas. A placa lisa produz gotas pequenas, enquanto a estriada produz gotas maiores. $\mathrm{Na}$ posição vertical, "sprays" com placa convexa produzem normalmente a maior área molhada, a placa côncava a menor e a plana é intermediária. Estes emissores operam normalmente em $140 \mathrm{KPa}$. Os aspersores de impacto de baixa pressão produzem gotas menores que os aspersores tradicionais que operam em $350 \mathrm{KPa}$, quando ambos operam em baixas pressões. Isto é conseguido pela passagem da água através de um ou mais bocais especiais não circulares que espalham o jato em forma de leque compacto e conseguem uma boa distribuição . Estes aspersores operam em $240 \mathrm{KPa}$, com diâmetro de alcance de 20 a $25 \mathrm{~m}$.

Os fabricantes de aspersores e pivôs centrais tem desenvolvido novos tipos de emissores e equipamentos, muitos dos quais projetados para aplicar água desde o topo da lateral do pivô até próximo do dossel da cultura. Alguns destes equipamentos operam em baixa pressão, apresentando a placa difusora giratória ou vibratória, tendo um 
diâmetro de alcance maior que os dispositivos com placa fixa (MARTIN et al., 1993). Os "sprays" giratórios começaram a ser utilizados a partir de 1989 , apresentando a placa difusora rotativa e estriada ( 4 ou 6 estrias). Conseguem com isso um aumento no raio de alcance e na superposição. Possuem um dispositivo de silicone fluido para controlar a velocidade de giro da placa, que pode ser rápida ou normal. Os modelos atualmente disponiveis operam com pressão minima de $70 \mathrm{Kpa}$ para o modelo "rotator" e $42 \mathrm{Kpa}$ para o modelo "spinner". Podem ser montados "on top" diretamente na tubulação da lateral ou em pendural (NELSON IRRIGATION, 1992). Outros dispositivos que estão sendo utilizados são o LEPA (aplicação localizada de baixa energia) e LEDIC (aplicação de baixa energia abaixo do dossel vegetativo) (MARTIN et al., 1993). As características de pressão e alcance das principais configurações de emissores utilizadas em pivô central são apresentadas na Tabela 2.

Tabela 2 - Faixas normais de pressão de operação e diâmetro de alcance associado para diferentes configurações de emissores mais utilizadas em pivô central.

\begin{tabular}{|c|c|c|}
\hline $\begin{array}{l}\text { Tho de Emissor e } \\
\text { Tenacamento }\end{array}$ & $\begin{array}{c}\text { Pressão } \\
\text { (KPa) }\end{array}$ & $\begin{array}{l}\text { DLâmetro de Alcance } \\
\text { (m) }\end{array}$ \\
\hline \multicolumn{3}{|l|}{ Spray de Batra Pressao Ftro } \\
\hline 1 - em pendural & $70-205$ & $3-9$ \\
\hline 2 - na lateral "on top" & $70-205$ & $6-14$ \\
\hline 3 - em boom" curto & $70-140$ & $12-18$ \\
\hline 4-em boom" longo & $105-170$ & $20-26$ \\
\hline \multicolumn{3}{|l|}{ Spray de Batra Pressioo Giratório } \\
\hline 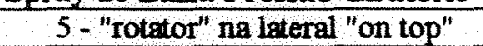 & $70-345$ & $15-21$ \\
\hline 6 - "rotator" em pendural & $70-345$ & $12-18$ \\
\hline 7 - "spinner" em pendural & $40-140$ & $10-14$ \\
\hline \multicolumn{3}{|l|}{ Impacto de Batra Pressao } \\
\hline 8 - espacamento variavel & $140-240$ & $18-23$ \\
\hline 9- espacamento semi-uniforme & $205-275$ & $21-24$ \\
\hline \multicolumn{3}{|l|}{ Impacto de Media Pressăo } \\
\hline 9 - espacamento variavel & $275-345$ & $27-34$ \\
\hline 10 - espacamento semi-uniforme & $275-380$ & $30-37$ \\
\hline \multicolumn{3}{|l|}{ Impacto de Alta Pressáo } \\
\hline 11 - espacamento uniforme & $380-450$ & $40-50$ \\
\hline
\end{tabular}

Adaptado de KELLER \& BLIESNER (1990) e NELSON IRRIGATION (1992)

a valores arredondados para múltiplos de $5 \mathrm{KPa}$ 


\section{4 - Utilização de energia}

Grande quantidade de energia é necessária para a operação de um pivô central de alta pressão. Splinter ${ }^{1}$, citado por SCALOPPI \& ALLEN (1993), declarou que a histónia pode recordar o desenvolvimento do pivô central como um dos mais significantes avanços na agricultura no século $\mathrm{XX}$, ou como o maior desastre , dependendo do custo da energia em relação ao valor da cultura sob o sistema.

Segundo GILLEY \& WATTS (1977), GILLEY \& SUPALLA (1983), e GILLEY et al. (1990), a redução da pressão de operação é a maneira mais fácil e econômica de reduzir o consumo de energia dos sistemas pivô central. De acordo com GILLEY (1984), os pivôs centrais de baixa pressão estão se tomando comuns e muitos sistemas de alta pressão estão sendo redimensionados para operar em pressão reduzida. Utilizando aspersores de alta pressão, uma pressão de 410 - $590 \mathrm{KPa}$ é requerida no ponto do pivô, enquanto que sistemas de baixa pressão requerem $130-200 \mathrm{KPa}$, resultando em considerável economia de energia, que pode ser de 20 a 40\% (GILLEY et al., 1983).

VON BERNUTH \& GLLEY (1985) estimam que nos Estados Unidos, cerca de $90 \%$ dos equipamentos instalados em 1984 foram projetados para trabalhar a pressões inferiores a $240 \mathrm{KPa}$ contra $80 \%$ projetados para pressões superiores a $450 \mathrm{KPa}$ nos anos anteriores.

ROLLAND (1982) calcula que para um pivô central com vazão de 204 $\mathrm{m}^{3}$ /h e uma perda de carga mais desnivel geométrico de 61 mca ( $598 \mathrm{KPa}$ ), a utilização de aspersores de alta pressão exige uma altura manométrica total de 117 mca (1148 KPa), e uma potência de 87,5 cv do conjunto motobomba. Com a utilização de "sprays", a altura manométrica total passa para $78,7 \mathrm{mca}(772 \mathrm{KPa})$ e a potência necessária da motobomba diminui para $58,7 \mathrm{cv}$.

1 SPLINTER, W. Adress to a Meeting of the Society of Automotive Engineers. Irrigation Journal 29 (5), p 42.1979 
A Tabela 3 mostra a influência do tipo de emissor na pressão no ponto do pivô e na taxa de aplicação máxima no final da lateral, considerando um sistema capaz de irrigar 52,6 ha ( $410 \mathrm{~m}$ de comprimento) e vazão de 0,10 a $0,151 / \mathrm{s} / \mathrm{m}$ de comprimento da lateral $\left(148-221 \mathrm{~m}^{3} / \mathrm{h}\right)$.

Tabela 3 - Pressão aproximada no ponto do pivô e taxa máxima de aplicação para cinco tipos de emissores utilizados em pivô central.

\begin{tabular}{|c|c|c|}
\hline Tipo de Emissor & $\begin{array}{c}\text { Pressão Aproximada no } \\
\text { Ponto do Pivó } \\
\text { (KPa) }\end{array}$ & $\begin{array}{c}\text { Taxa Máxima de } \\
\text { Aplicacão } \\
\text { (mm/h) }\end{array}$ \\
\hline Impacto de alta pressão & $450-520$ & 29 \\
\hline Impacto de média pressão & $275-350$ & 41 \\
\hline Impacto de baixa pressão & $170-240$ & 57 \\
\hline Spray $360^{\circ}$ & $170-240$ & 115 \\
\hline Spray $180^{\circ}$ & $170-240$ & 191 \\
\hline
\end{tabular}

Fonte : GILLEY (1984)

A utilização de emissores de baixa pressão pode ser acompanhada das seguintes desvantagens:

- redução da área molhada, provocando aumento na taxa de aplicação, predispondo à ocorrência de escoamento superficial (VON BERNUTH \& GILLEY ,1983; LONGLEY et al. ,1983; GILLEY et al. ,1983; SILVA, 1989)

- redução da uniformidade de aplicação de água devido à diminuição do raio de alcance e portanto, reduzindo a superposição VON BERNUTH \& GILLEY, 1983; SILVA, 1989)

- maior sensibilidade às variações de pressão em terrenos declivosos (FVANS ,1980; JAMES et al. ,1982; VON BERNUTH \& GILLEY ,1983); sendo necessánio reguladores de pressão para uniformizar a vazão.

- aumento do tamanho de gotas, devido ao decréscimo na pressão e aumento do diâmetro dos bocais (VON BERNUTH \& GILIEY,1983); isto exige a utilização de placas ou bocais difusores, para fracionamento das gotas. 
- alteração do padrão triangular de distribuição por formas que acarretam taxas mais elevadas próximas à extremidade do jato, além de choque entre gotas de emissores adjacentes (VON BERNUTH \& GILLEY ,1983; SILVA ,1989)

- aumento da sensibilidade às perdas pelo vento e evaporação (SILVA ,1989; KELLER \& BLIESNER , 1990)

- necessidade de instalação de dispositivos para minimizar os problemas citados, elevando os custos (VON BERNUTH \& GILLEY,1983); estes dispositivos são os reguladores de pressão, os diferentes modelos de placa difusora, os "sprays" giratónios e o "spray boom".

- necessidade de instalação de bomba "booster" quando se utiliza canhão final, para elevar a pressão no final da lateral (GILLEY \& WATTS, 1977; GILLEY \& SUPALLA,1983; GILLEY et al., 1990).

\section{5 - Uniformidade de aplicação de água}

Segundo KINCAID et al. (1969), o sistema pivô central é capaz de aplicar água com alta uniformidade, utilizando-se bocais de tamanho adequado e operando na pressão recomendada. A limitação na disponibilidade de diâmetros de bocais pode limitar a uniformidade de alguns equipamentos (HEERMAN et al., 1990).

De acordo com GILLEY \& MIELKE (1980) e EVANS (1980), a alta uniformidade conseguida por emissores de alta pressão é devida ao alto grau de sobreposição; em emissores de baixa pressão, o reduzido raio de alcance reduz a sobreposição e cuidados especiais devem ser tomados na seleção do tamanho do bocal e espaçamento, para se conseguir uniformidades aceitáveis. Tooyamani et all, citados por

1 TOOYAMANI, K.P.; NORUM, D.I; DUBETS, S. Application Rates and Uniformity under Center Pivot Sprinklet Irrigation Systems Using Spray Nozzles. Canadian Agricultural Engtneertng 29: p 149. 1987 
REZENDE (1992), após analisarem 8 sistemas pivô central de baixa pressão, conchúram que é possível obter uma alta uniformidade de aplicação, desde que os bocais sejam dimensionados e espaçados adequadamente .

GILLEY et al. (1983), utilizando um pivô central modificado para utilizar diferentes tipos de emissores (aspersor de impacto de alta e baixa pressão e spray") conclúram que o movimento descontínuo das torres é um fator que afeta a uniformidade de água em sistemas de baixa pressão. O conceito de uniformidade circular pode ser importante em sistemas que utilizam "sprays" e aplicam pequenas lâminas por irrigação. A uniformidade radial não foi significativamente diferente para os emissores estudados.

Deve-se fazer uma adequada combinação de parâmetros (modo de montagem, modelo de placa difusora, tipo de spray) para não ocorrer problemas de recobrimento, colisão entre gotas e instabilidade de aplicação devido às oscilações causadas pelo vento e pelo próprio movimento do pivô (SILVA,1989)

REZENDE (1992), estudando a uniformidade de aplicação de um pivô central equipado com emissores tipo spray, operando em um solo tipo Terra Roxa Estruturada, concluiu que a redistribuição da água no perfil do solo deve ser considerada na análise da uniformidade de aplicação de água que abaixo da superfície do solo depende pouco da uniformidade acima do solo, mesmo no caso onde acima do solo a uniformidade foi baixa.

\section{6 - Desempenho do Equipamento}

COTRIM (1988), analisando o desempenho de pivôs centrais de baixa pressão e comparando com os resultados obtidos por BRIDI (1984) em pivôs de alta pressão, concluiu que os valores de CUC (Coeficiente de Uniformidade de Christiansen) 
foram muito próximos, enquanto a precipitação instantânea foi muito maior nos pivôs equipados com "sprays". Não houve diferença de pressão no ponto do pivô dos sistemas de alta e baixa pressão, e o autor concluiu que não estaria havendo diferença no consumo de energia para os pivôs estudados. Esta contradição pode ser explicada pela maior vazão por hectare irrigado nos equipamentos de baixa pressão, que segundo o autor, poderiam ter a pressão reduzida sem prejuizo de desempenho.

JAMES \& BLAIR (1984), utilizando um modelo computacional para simular a operação de sistemas pivô central de baixa e alta pressão em diferentes topografias, conchuíram que os sistemas com aspersores de impacto de baixa pressão e "sprays" consumiram respectivamente, 82 e $68 \%$ da energia usado pelo sistema de aspersores convencionais de alta pressão. Todos os sistemas apresentaram CUC acima de $90 \%$ Sistemas de baixa pressão apresentaram taxas de aplicação média e máxima acima de 50 e $100 \mathrm{~mm} / \mathrm{h}$, respectivamente, enquanto o sistema de alta pressão apresentou taxas média e máxima abaixo de 20 e $50 \mathrm{~mm} / \mathrm{h}$, repectivamente.

TELXEIRA (1992), estudando o efeito de diferentes tipos de emissores na performance de um pivô central de $166 \mathrm{~m}$ de raio, concluiu que o diâmetro molhado dos emissores tipo "rotator" foi superior ao do spray fixo para uma mesma vazão $(12,1$ e 8,5 m no início e 18,9 e $12,0 \mathrm{~m}$ no final da lateral), resultando numa taxa de aplicação menor ( 8 e $18 \mathrm{~mm} / \mathrm{h}$ no início e 22 e $50 \mathrm{~mm} / \mathrm{h}$ no final da lateral). Estudando também o modo de instalação do emissor, concluiu que a uniformidade de irrigação e a perda pelo vento diminuíram e a taxa de aplicação aumentou à medida que se aproximou os emissores do nível do solo através de pendurais. Para a condição estudada, recomendou a instalação dos emissores a $2,0 \mathrm{~m}$ do solo.

ABO-GHOBAR (1992) estudou as perdas por evaporação sob condições de clima desértico em três pivôs de baixa pressão, variando a altura do emissor, as perdas 
foram de $15,6,21,2$ e $35,8 \%$ para as alturas de respectivamente, $1,25,1,75$ e $2,50 \mathrm{~m}$ do solo.

O efeito de diferentes configurações de emissores na produção de culturas irrigadas tem sido estudado por vários autores. WILHELM el al. (1985) não encontraram diferenças na produção de milho durante quatro anos sucessivos de cultivo, para aspersores de impacto de alta e baixa pressão e "spray. GILLEY et al. (1986) não encontraram diferenças no desenvolvimento radicular e na produção de milho, utilizando os mesmos tipos de emissores. DEBOER et al. (1992) utilizaram aspersores de impacto de alta e média pressão e também não encontraram diferenças significativas na produção de milho. Entretanto, UNDERSANDER et al. (1985), estudando o desempenho de aspersores de alta pressão e "sprays", associado com 3 sistemas de cultivo do solo, conchúram que não houve diferença significativa entre as perdas por evaporação para os dois tipos de emissores. Não houve diferença de produção da cultura do sorgo, enquanto o milho produziu significativamente mais sob 0 aspersor de alta pressão. Os autores atribuíram esta diferença à sensibilidade do milho ao selamento superficial. $O$ escoamento superficial foi maior no sistema de baixa pressão, sendo reduzido pelo cultivo mínimo e subsolagem e eliminado pela construção de diques entre as linhas de plantio.

VON BERNUTH \& GILEY (1985) desenvolveram um modelo para avaliar diferentes configurações de emissores operando em diferentes tipos de solos, considerando diferentes valores de armazenamento superficial. $O$ efeito na redução da infiltração pelo impacto da gota d'água na superficie do solo foi estudado para cada configuração de emissores, considerando o tamanho e velocidade de gotas e a textura do solo. Um estudo econômico de cada tipo de emissor fó apresentado, em função do volume de escoamento superficial e consumo de energia. Conchúram que a escolha deve ser feita em função da vazão do equipamento, capacidade de armazenamento superficial e tipo de solo, em ordem decrescente de importância Os sistemas equipados com "spray" 
foram os mais recomendáveis na maioria das situações, principalmente em solos arenosos com algum armazenamento superficial.

\section{7 - Problemas de manejo de solo e água}

Segundo WILHELM et al. (1985) a utilização dos sistemas pivô central de baixa pressão deve aumentar com o desenvolvimento da agricultura irrigada; estes equipamentos tem potencial para economizar energia, mas também apresentam problemas de manejo de água e solo, como verificado por vários autores.

MICKELSON \& SCHWEIZER (1987), estudando o efeito da redução de pressão e de sistemas de cultivo, concluiu que a conversão da pressão de um pivô central de $380 \mathrm{KPa}$ para $138 \mathrm{KPa}$ aumentou o volume de escoamento superficial de $30 \%$ em média, para os três sistemas de cultivo estudados, num solo com $3,8 \%$ de declive cultivado com milho.

A uniformidade da umidade no perfil do solo pode ser consideravelmente reduzida pelo escoamento superficial em solos com baixa capacidade de infiltração (KINCAID et al., 1969).

O aumento do escoamento superficial pode ter também aspectos ambientais negativos. Dependendo da topografia e tipo de solo, o escoamento superficial aumenta as perdas de solo (GILLEY et al., 1983). KOLUVEK et al. (1993) relatam perdas de até 33 tha de solo.

De acordo com WILMES et al. (1992), na maioria das decisões de projeto e manejo, a seleção da configuração de emissores envolve aspectos econômicos e ambientais. A seleção de emissores de baixa pressão irá diminuir os custos de bombeamento para um dado volume de água, mas pode também aumentar o escoamento 
superficial, reduzindo a eficiência do sistema. $\mathrm{O}$ aumento do volume de água necessário para compensar o volume de escoamento superficial pode anular os beneficios da redução de pressão (GILLEY \& MIELKE, 1980; WILMES et al., 1992).

Os problemas associados ao manejo de solo e água quando se utiliza pivôs centrais de baixa pressão variam em função do tịpo de solo, topografia, cultura e práticas culturais (GILLEY \& MIELKE, 1980).

GILLEY et al. (1983) e GILLEY et al. (1986), estudando o efeito de diferentes configurações de emissores e vários sistemas de cultivo, conchúram que a chave para o sucesso na operação de sistemas pivô central de baixa pressão está na eliminação do escoamento superficial durante a aplicação de água.

\section{8 - Sistemas de cultivo}

A necessidade de desenvolver sistemas de cultivo em agricultura irrigada que possam controlar o escoamento superficial e permitir a utilização de sistemas de baixa pressão em diferentes tipos de solos e topografias é defendida por autores como GILLEY et al. (1983), GILLEY et al. (1986), HEERMANN et al. (1990) e KELLER \& BLIESNER (1990).

Sistemas de cultivo reduzido que mantenham resíduos vegetais na superficie do solo, protegendo-o da erosão e aumentando o armazenamento superficial podem minimizar o problema do escoamento superficial (GILLEY et al.,1983; WILHELM et al.,1985; GILLEY et al.,1986).

WILHELM et at. (1985), comparando sistemas de alta e baixa pressão associados com diferentes tipos de cultivo na produção de milho, concluíram que a 
utilização de sistemas de pressão reduzida associados com cultivo mínimo pode reduzir os custos sem afetar a produção.

AARSTAD \& MILLER (1973) concluíram que a construção de pequenas bacias entre as linhas de plantio reduziram o escoamento superficial de 40 para $1 \%$, num solo com $7 \%$ de declive cultivado com batata e beterraba.

MOHAMOUD et al (1992), utilizando um modelo para dimensionamento de sistemas pivô central, concluiram que é necessário a utilização de aspersores de alta pressão para evitar escoamento superficial em solo sob sistema convencional de cultivo, enquanto o plantio direto permitiu a utilização de emissores de baixa pressão.

MARTIN et al. (1993) observaram que a utilização de equipamentos tipo LEPA sem sistema de cultivo para armazenar o excesso de aplicação pode resultar em substancial quantia de escoamento superficial. A utilização de "sprays" abaixo do dossel vegetativo na maioria dos casos provocou menos escoamento superficial que o sistema LEPA.

\section{9 - Escoamento superficial}

KELSO \& GILLEY (1983) definem o escoamento superficial potencial como a água não infiltrada que se encontra em estado transitório, mais o armazenamento superficial temporário na superfície do solo. Ė função das características de aplicação de água do sistema de írigação e condições do solo.

De acordo com KINCAID et al. (1969), o escoamento superficial potencial é definido como a porção de água que é aplicada numa taxa que excede a infiltração do solo, tomando-se disponivel para escoamento. Pode ser calculado 
teoricamente pela integração da área entre a curva de aplicação e a curva de infiltração, no intervalo de tempo em que a aplicação excede a infiltração.

HERMANN \& HEIN (1968) calcularam o potencial de escoamento superficial de água no solo em sistemas pivô central assumindo uma única curva de infiltração em toda a área irrigada, e os resultados obtidos foram proporcionais à distância do centro do pivô.

Segundo JOHNSON et al. (1987) a vazão e tamanho do equipamento, taxa de aplicação dos emissores, lâmina aplicada e infiltração do solo afetam o volume de escoamento superficial durante uma irrigação por pivô central. Em geral, a taxa de escoamento superficial aumenta com a distância ao centro do pivô; entretanto, KINCAID et al. (1969) afirmam que o escoamento superficial pode ser importante perto do pivô, porque apesar da baixa taxa de aplicação, o tempo de aplicação é longo, e portanto o solo atinge baixas taxas de infiltração.

ADDNNK et al. (1975) estudaram o efeito do perfil de aplicação dos emissores na ocorrência de escoamento superficial e concluíram que este efeito depende do tipo de solo. A utilização do perfil assimétrico com o jato dirigido no sentido do deslocamento do pivô reduziu o escoamento superficial em média $11 \%$, para todos os tipos de solos estudados.

Segundo GILLEY \& MELKE (1980), mesmo em sistemas de alta pressão pode ocorrer escoamento superficial; KINCAID et al. (1969) encontraram valores superiores a $22 \%$ em pivô equipado com aspersores de impacto de alta pressão. GILLEY \& MIELKE (1980) mediram o escoamento superficial em uma cultura de milho completamente desenvolvida e encontraram valores de 25,9 e $28 \%$ para aspersores de alta pressão, aspersores de baixa pressão e "sprays". O menor escoamento ocorrido com o aspersor de baixa pressão foi atribuido ao maior "stand" da cultura. 
WILMES et al. (1992) desenvolveram um modelo de análise de desempenho de diferentes configurações de emissores (alta, média e baixa pressão) que permite a previsão do desempenho do pivô (uniformidade de irrigação, consumo de energia e aspectos econômicos) e de ocorrência de escoamento superficial em diferentes locais e condições de solo, utilizando um mapa de solos digitalizado da área irrigada.

O escoamento superficial pode ser reduzido pelos seguintes procedimentos:

- reduzir a vazão do sistema (MERRIAM et al, ,1973; GILLEY \& MIELKE , 1980); isto pode ser feito considerando as precipitações prováveis, capacidade de armazenamento do solo e consumo de água pelas culturas; entretanto, corre-se slgum risco de redução de produção (GILLEY \& MIELKE , 1980).

- aumento da velocidade de rotação do pivô ( KINCAID et al. ,1969; DILlON et al.,1972; MERRIAM et al. ,1973; EVANS ,1980; GILLEY \& MIELKE ,1980; ALENCAR ,1988; KELLER \& BLIESNER ,1990; TROUT et al. ,1990); isto diminui a lâmina por irrigação, embora não altere a taxa máxima de aplicação; velocidades mais rápidas aumentam as perdas pelo vento e evaporação, diminuindo a eficiência, e requerem mais revoluções por ciclo da cultura, aumentando o desgaste e a energia para movimentação do equipamento e a compactação pelas rodas das torres (EVANS, 1980; GILLEY \& MIELKE, 1980 ); os beneficios do aumento da velocidade (irrigações mais frequentes) são reduzidos porque, com o solo umedecido mais frequentemente, a curva de infiltração se encontrará mais à direita (KELLER \& BLESNER, 1990), e portanto o solo encontra-se com menor capacidade de infiltração.

- modificar o perfil de aplicação, através da seleção de emissores com taxas de aplicação mais próximas da capacidade de infiltração do solo (HEERMANN \& HENN, 1968; DILLON et al, 1972; GLLEY \& MIELKE, 1980; ALENCAR, 1988; TROUT et 
al.1990; MOHAMOUD et al., 1992) ou instalação de "spray boom" (TROUT et al.,1990; MOHAMOUD et al., 1992).

- limitar o comprimento da lateral do pivô (HEERMANN \& HEIN, 1968; ROLLAND, 1982); entretanto, este procedimento reduz a viabilidade econômica do equipamento, pelo aumento do custo por área irrigada (ROLLAND, 1982).

- práticas culturais, utilizando sistemas de cultivo que aumentem a capacidade de infiltração e o armazenamento superficial, e protejam o solo contra o selamento superficial (EVANS,1980; GILLEY \& MIELKE ,1980; ALENCAR, 1988; KELLER \& BLIESNER, 1990; MOHAMOUD et al.,1992)

- construção de bacias de armazenamento, utilizando implementos específicos que constroem diques e sulcos entre as linhas de plantio (TROUT et al, 1990); entretanto, esta operação é cara e difícil, e é desfeita ao longo das irrigações (KELLER \& BLIESNER, 1990).

\subsection{0 - Infiltração}

KELSO \& GILLEY (1983) afirmam que existem poucos estudos sobre infiltração e escoamento superficial sob taxa de aplicação variável que ocorre no pivô central. Neste sistema, o perfil da taxa de aplicação depende da vazão, comprimento da lateral, velocidade de deslocamento e tipo de emissor utilizado. De acordo com SKAGGS et al. (1983) no período em que a capacidade de infiltração excede a taxa de aplicação , a água irá infiltrar-se tão rapidamente quanto é aplicada e a infiltração será controlada pela aplicação; entretanto, a capacidade de infiltração pode tornar-se com o tempo menor que a taxa de aplicação; então a superficie do solo ficará saturada e a água aplicada em excesso irá tornar-se disponível para o armazenamento ou escoamento superficial. 
O armazenamento superficial nas macro e micro depressões do solo pode desempenhar um importante papel na minimização do escoamento superficial, especialmente quando a lâmina aplicada é pequena. Depende principalmente do declive, micro topografia e rugosidade da superficie do solo. Normalmente é igual a $12,5 \mathrm{~mm}$ quando o declive é zero, reduzindo $2,5 \mathrm{~mm}$ para cada $1 \%$ de aumento do declive (KELLER \& BLIESNER, 1990).

Os fatores que afetam a infiltração são as propriedades do solo (textura, estrutura), declividade, conteúdo inicial de água, taxa de aplicação, selamento e encrustamento superficial (SKAGGS, 1983).

O selamento superficial é causado pelo impacto das gotas d'água, que destroem a estrutura da camada superficial do solo e provocam a deposição de argila nos poros, formando uma camada compactada. Embora tenha pequena espessura, essa camada exerce grande influência nas características de infiltração do solo (MOORE \& LARSON, 1980). O selamento superficial depende principalmente da energia das gotas, taxa de aplicação, textura e estrutura do solo. Como primeira aproximação, sugere-se uma redução entre 15 e $25 \%$ na infiltração pela utilização de aspersores de impacto de média e baixa pressão (GILLEY, 1984).

Segundo MOHAMOUD et al. (1992) as áreas irrigadas por pivô central podem receber uma variedade de sistemas de cultivo, que podem afetar a variabilidade espacial e temporal da capacidade de infiltração, através da formação ou prevenção de encrustamento superficial e camadas compactadas.

Segundo KELSO \& GILIEY (1983) não existe uma técnica definitiva para medir infiltração em área irrigada por pivô central. KINCAID et al. (1969) desenvolveram uma técnica para modificar matematicamente a curva de infiltração obtida pelo infiltrômetro de anel, no intervalo de tempo em que a superficie do solo sob taxa de aplicação variável ainda não se encontra saturada; assumiram que a taxa de infiltração em 
algum instante é função da lâmina infiltrada até aquele instante, melhorando a estimativa do escoamento superficial em relação à função não modificada.

DILLON et al. (1972) apresenta uma técnica alternativa para mensuração da infiltração utilizando o prớprio equipamento pivô central, que deve permanecer estacionário, baseada no tempo de saturação da superficie do solo e taxa de aplicação ao longo do raio de alcance dos emissores.

De acordo com KELLER \& BLIESNER (1990), o método de determinação da infiltração deve simular as condições de irrigação que ocorrem em áreas sob sistemas pivô central, e por isso o infiltrômetro de aspersor deve ser utilizado. Métodos para determinação de infiltração por aspersão em que a água é aplicada sob taxa constante foram desenvolvidos por Tovey \& Pair $^{1}$, Dixon \& Peterson ${ }^{2}$, citados por SKAGGS et al. (1983), em que a infiltração é medida pela diferença entre aplicação e escoamento superficial; ou pelo tempo de saturação do solo, utilizando os infiltrômetros de Beggs ${ }^{3}$ e Reinders \& Louw ${ }^{4}$, citados por KELLER \& BLIESNER (1990).

KELSO \& GILLEY (1983) desenvolveram um equipamento portátil eletrônico a partir do infiltrômetro de Purdue-Winsconsin para estimar a taxa de infiltração do solo sob pivô central, através da determinação da taxa de aplicação e do escoamento superficial. Esta metodologia foi aplicada em uma cultura de milho com diferentes sistemas de cultivo do solo, irrigada por pivô central equipado com aspersores de alta e baixa pressão e "sprays". Foram determinados a taxa de aplicação acima e abaixo do dossel vegetativo e o escoamento superficial e desenvolvida uma metodologia para obtenção e análise matemática dos dados.

1 TOVEY, R.; PAIR, C.H. Measurement of Intake Rate for Sprinkler Irrigation Design. Transactions of ASAE. St. Joseph, $9: 359-63.1966$

2 DIXON, R.M.; PETERSON, A.E. Construction and Operation of a Modified Spray Infiltrometer and a Flow Infiltrometer. Res. Rep. 17. Esp. Sta., University of Winsconsin, Madson, 1964.

3 BEGGS, R.G. A Portable Field Sprinkler Infitrometer. Logan, Utah State University. 1981 (MS Thesis)

${ }^{4}$ REINDERS, F.B.; LOUW, A.A. The Measurement of a Infiltration as a Design Imput for Mechanized Irrigation Systerns. S. A. Irrigation. 7(1):9-21. 1985 
KELLER \& BLIESNER (1990) recomendam que os testes de infiltração devem ser feitos na região da periferia da área irrigada, onde a taxa de aplicação é maior. Para simular as condições de umidade e selamento típicos de solos irrigados por pivô central, deve-se molhar o solo previamente e esperar secar uma camada superficial de 10$20 \mathrm{~mm}$, antes de iniciar o teste de infiltração.

Segundo PRUSKI et al. (1993) a capacidade de infiltração em um solo recém preparado é alta, em razão da quebra da estrutura da camada superficial, ocorrendo posteriormente a redução com o selamento superficial. Analizando o escoamento superficial em solo com e sem cobertura, concluíram que foi consideravelmente menor no solo coberto, aumentando ao longo das irrigaçōes para o solo coberto e descoberto.

EVANS (1980) observa que o período de máximo consumo de água pelas culturas, e portanto de maior necessidade de irrigação, ocorre aproximadamente no meio do ciclo das culturas, quando o solo já apresenta menor capacidade de infiltração, devido ao selamento superficial. Nesta época espera-se maior ocorrência de escoamento superficial.

\subsection{1 - Presença do dossel vegetativo}

De acordo com HEERMAN \& KOHL (1983), o projeto de sistemas de irrigação móveis deve considerar o armazenamento superficial e a intercepção foliar quando a taxa de aplicação excede a infiltração; a intercepção foliar geralmente não é considerada no projeto, porque os sistemas são projetados para irrigar solos nús.

Segundo STEINER et al. (1983), as perdas por evaporação e interceptação das plantas ocorrem na irrigação por aspersão e devem ser avaliadas quando se objetiva comparar a eficiência de aspersores e equipamentos. Observaram que numa 
cultura de milho com o dossel vegetativo completamente desenvolvido, a maior parte da água que atinge o topo da cultura chega ao solo indiretamente, escorrendo pelas folhas e caule, não havendo diferença quando a água é aplicada por chuva ou irrigação. Essa interceptação depende da frequência e época de irrigação, lâmina aplicada e condições atmosféricas. O dossel vegetativo do milho é capaz de armazenar água; essa capacidade varia com o IAF (índice de área foliar), espaçamento entre plantas, e características varietais, sendo relativamente constante após o desenvolvimento completo. A percentagem de armazenamento varia com a lâmina aplicada. Estimaram um armazenamento foliar de $2,7 \mathrm{~mm}$ por aplicação de água, quando o IAF foi maior que 3.

AYARS et al (1991), testando vários níveis de uniformidade acima do dossel vegetativo de uma cultura de algodão irrigada por sistema lateral móvel, observaram que a uniformidade foi maior abaixo do dossel vegetativo, sendo afetada pela altura de plantas, LAF e distribuição das folhas. A uniformidade aumentou com o acréscimo da lâmina aplicada, sendo que quando foi alta acima do dossel vegetativo, fơ alta abaixo, mesmo quando a lâmina aplicada foi pequena. 


\section{3 - METODOLOGIA}

\section{1 - Caracterização da área e do sistema pivô central}

O trabalho experimental foi realizado utilizando-se o equipamento pivô central do Departamento de Engenharia Rural da ESALQ/USP, localizado na Fazenda Areão, Piracicaba, SP, cujas coordenadas geográficas são: latitude $22^{\circ} 43^{\prime} \mathrm{S}$, longitude $47^{\circ} 38^{\prime} \mathrm{W}$ e altitude $560 \mathrm{~m}$.

O pivô central possui as seguintes caracteristicas:

modelo : DANMATIC MD400/BP 4TVC

comprimento da lateral : $166,4 \mathrm{~m}$

número de torres : 04

comprimento dos vãos : inicial - 40,1 m

$$
\begin{aligned}
& \text { intermediários - 38,6 m } \\
& \text { final (balanço) - 10,6 m }
\end{aligned}
$$

altura em relação ao solo : $3,45 \mathrm{~m}$

diâmetro da lateral : $65 / 8^{\prime \prime}(163,8 \mathrm{~mm})$

propulsão : elétrica (motores de $1,0 \mathrm{cv}, 480 \mathrm{~V}$ )

velocidade da última torre a $100 \%: 172 \mathrm{~m} / \mathrm{h}$

suprimento de água : motobomba diesel

área irrigada : com canhão final - 11,5 ha ; sem canhão final - 8,7 ha 
Para a execução do trabalho, foi feita uma simulação na região do último vão e balanço final, dimensionando-se os bocais para as características do seguinte equipamento, que é representativo da média dos equipamentos em operação no Brasil: comprimento da lateral : $500 \mathrm{~m}$ área irrigada : 78,5 ha raio da última torre : $489,4 \mathrm{~m}$ velocidade da última torre a $100 \%: 172 \mathrm{~m} / \mathrm{h}$ tempo de revolução a $100 \%: 17,77 \mathrm{~h}$ lâmina bruta : $8 \mathrm{~mm}$ em $24 \mathrm{~h}$ vazão : $260,8 \mathrm{~m}^{3} / \mathrm{h}$ canhão final : ausente

A área onde está instalado o pivô possui solo classificado como Terra Roxa Estruturada (Alfisol), série Luíz de Queiroz, com declividade média variando de 2,5 $\%$ em aclive a $8,8 \%$ em declive.

A parcela experimental consistiu de uma faixa de $250 \times 10 \mathrm{~m}$, localizada entre a última torre e a extremidade final da lateral (sob o balanço final), conforme Figura 1.

O solo da parcela apresentou as seguintes características, determinadas no laboratório de física do solo do DER/ESALQ: composição textural : areia $21 \%$; silte $26 \%$; argila $53 \%$ densidade aparente na camada de $0-30 \mathrm{~cm}: 1,31 \mathrm{~g} / \mathrm{cm}^{3}$ curva de retenção na camada de 0 a $30 \mathrm{~cm}$ : Figura 2

A declividade da parcela foi de $5,5 \%$ no sentido transversal e $0,5 \%$ no sentido longitudinal. 


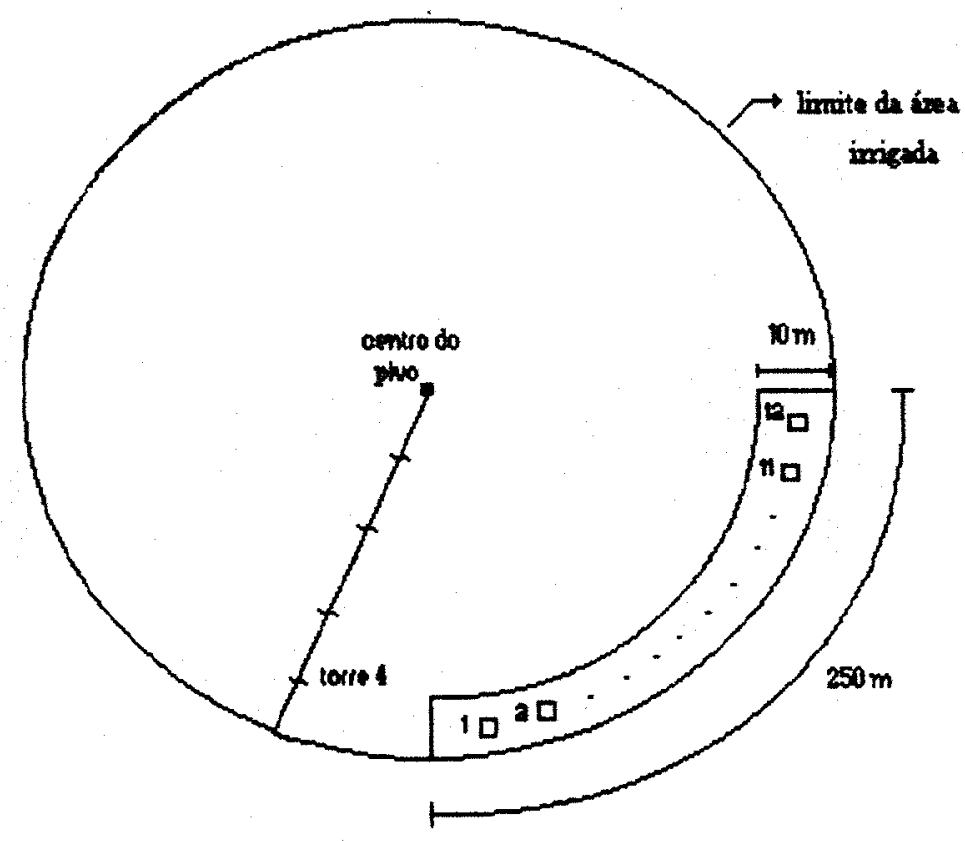

Figura 1 - "Lay out" da localizacão da área experimental

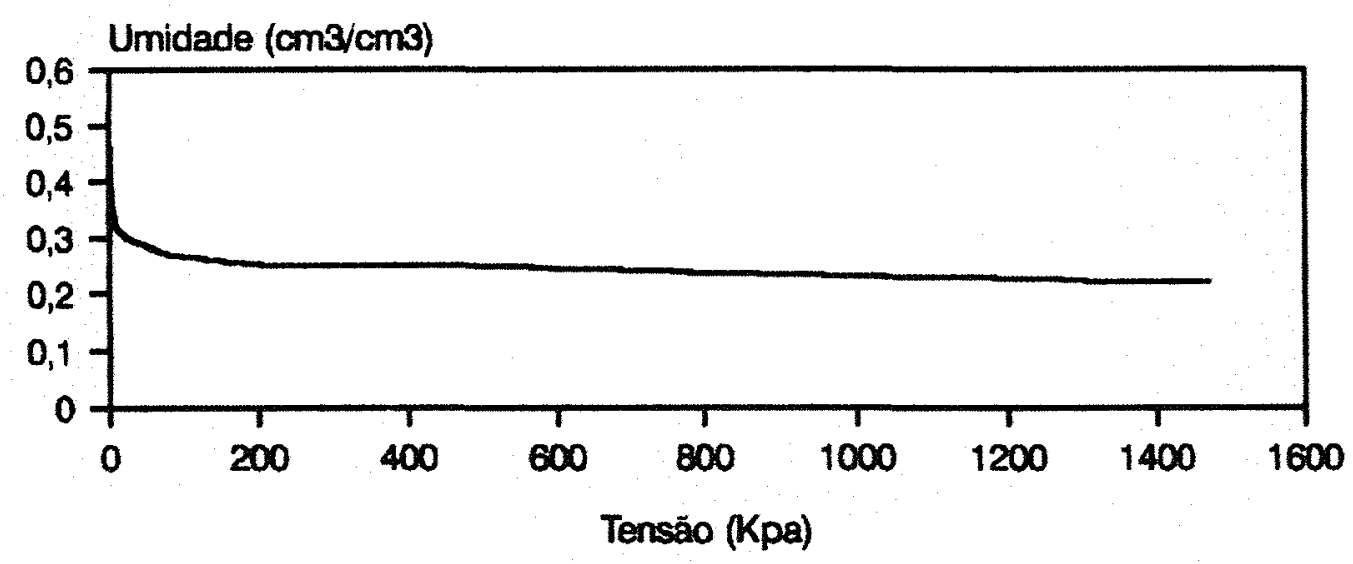

Figura 2 - Curva de retenção de água do solo da área experimental

A equação de ajuste dos dados da curva de retenção ao modelo de Van Genuchten é: 


$$
\theta=0.175+\frac{0.395}{\left[1+\left(0.538018\left|\psi_{m}\right|\right)^{1.240963}\right]^{0.194174}}
$$

em que :

$\theta$ - umidade do solo $\left(\mathrm{cm}^{3} / \mathrm{cm}^{3}\right)$

$\psi_{m}$ - tensão de água no solo (centímetros de coluna de água)

Ao longo da área experimental, foram instalados 12 pontos de medição de taxa de aplicação e escoamento superficial (Figura 1), espaçados entre sí de $20 \mathrm{~m}$, localizados no mesmo raio em relação ao centro do pivô, sob a metade do balanço final (a $161 \mathrm{~m}$ do centro do pivô existente, a $495 \mathrm{~m}$ do centro do pivô simulado). Esta localização foi escolhida para evitar problemas de uniformidade de aplicação de água próximo à última torre (excesso, devido aos respingos na estrutura da torre) e à extremidade da lateral (déficit, devido à pouca sobreposição).

\section{2 - Dispositivos de coleta de lâmina aplicada e escoamento superficial}

Para coletar a água do escoamento superficial, foi desenvolvido um dispositivo a partir do modelo utilizado por ALENCAR (1988), modificado para permitir a obtenção de dados de taxa de escoamento superficial. As calhas consistiram de chapas de ferro de $1,2 \mathrm{~mm}$ de espessura, com $20 \mathrm{~cm}$ de largura e comprimento conforme a Figura 3.

A calha possui forma pentagonal, área de $3,93 \mathrm{~m}^{2}$, com os lados acopláveis, de modo a permitir a desmontagem e transporte no campo. As laterais são cravadas no solo numa profundidade de $10 \mathrm{~cm}$, para evitar a entrada ou saida de água superficial, e unidas nas extremidades pelos encaixes. O escoamento coletado é conduzido 
até um recipiente através de um tubo de PVC de $100 \mathrm{~mm}$ de diâmetro e $1,4 \mathrm{~m}$ de comprimento.

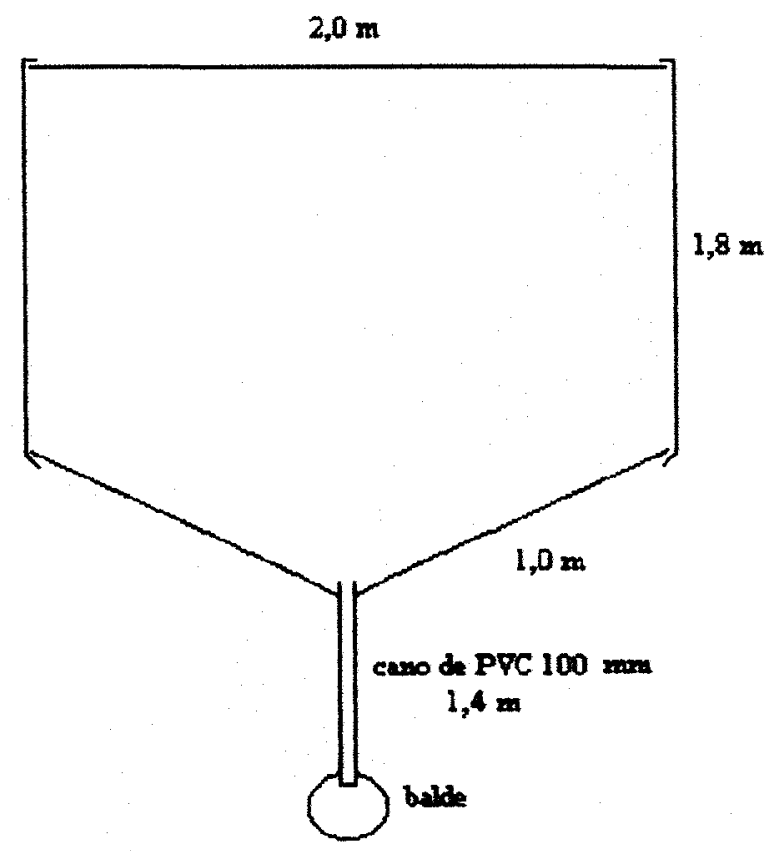

Figura 3 - Esquema construtivo das calhas coletoras de escoamento

O escoamento superficial foi coletado em baldes plásticos de 15 litros, com diâmetro de $29 \mathrm{~cm}$. A cada intervalo de tempo, o balde fơ trocado e o volume medido em recipiente de 13 litros, graduado de $200 \mathrm{ml}$. Para minimizar o erro devido ao volume de água aplicado pelo pivô diretamente no balde, foram instalados de cada lado deste, 2 coletores, que também foram substituídos e lidos a cada intervalo de tempo. $O$ volume coletado foi corrigido pela razão entre a área dos dois coletores e a do balde e subtraído do volume coletado pelo balde em cada intervalo.

$$
V_{t}=V b_{t}-\left(3.8141 V c_{t}\right)
$$

onde :

$V_{t}$ - volume corrigido de escoamento no tempo $t\left(\mathrm{~cm}^{3}\right)$

$\mathrm{Vb}_{\mathrm{t}}$ - volume coletado no balde no tempo $t\left(\mathrm{~cm}^{3}\right)$

$V c_{t}$ - volume dos dois coletores no tempot $\left(\mathrm{cm}^{3}\right)$ 
Para transformar o volume em lâmina, foi considerada a área da calha, através da fórmula:

$$
L_{t}=\frac{V_{t} / 1000}{3.93}
$$

em que :

$L_{t}$ - lâmina de escoamento no tempo $t(\mathrm{~mm})$

$V_{t}$ - volume de escoamento no tempo $t\left(\mathrm{~cm}^{3}\right)$

A lâmina de escoamento em cada intervalo foi transformada em lâmina acumulada. O tempo de ocorrência de escoamento foi contado a partir do início de aplicação de água na calha. Considerou-se para efeito de cálculo, o tempo médio de cada intervalo como o representativo do intervalo considerado.

Para determinação da taxa de aplicação, foram utilizadas linhas de coletores de alumínio de $10,5 \mathrm{~cm}$ de diâmetro e $12 \mathrm{~cm}$ altura, instalados em tripés a $30 \mathrm{~cm}$ do solo. O tempo de aplicação foi estimado dividindo-se o diâmetro de alcance do emissor em teste pela velocidade de deslocamento da última torre; o tempo estimado foi dividido em intervalos de 1 a 3 minutos, dependendo do emissor utilizado; foi adotado o limite mínimo de $1 \mathrm{~min}$, por questão de operacionalidade. O número de coletores em cada linha foi calculado dividindo-se o tempo de aplicação pelo intervalo de tempo adotado. O número necessário estimado de coletores em cada linha foi acrescido de 4 unidades, para melhorar a estimativa da lâmina total coletada.

Os coletores foram numerados de acordo com o total de intervalos. Durante a aplicação, após cada intervalo, o coletor correspondente foi vedado por tampa plástica; a leitura do volume foi feita utilizando proveta de $250 \mathrm{~cm}^{3}$, graduada de $2 \mathrm{~cm}^{3}$, imediatamente após a passagem do pivô, para evitar perdas por evaporação. A leitura da proveta em volume foi transformada em lâmina pela equação (7) : 


$$
L_{t}=10 \frac{V c_{t}}{86.59}
$$

em que :

$\mathrm{L}_{\mathrm{t}}$ - lâmina do coletor correspondente ao tempo $\mathrm{t}(\mathrm{mm})$

$\mathrm{Vc}_{\mathrm{t}}$ - volume do coletor correspondente ao tempo $t\left(\mathrm{~cm}^{3}\right)$

Para minimizar os erros devido à desuniformidade radial e circular do pivô e os efeitos do deslocamento da lateral sobre as calhas, foram utilizadas 2 linhas de coletores de cada lado da calha, numeradas em sentido contrário, conforme Figura 4, $\mathrm{O}$ cálculo do volume coletado em cada intervalo foi considerado como a média dos coletores respectivos das 4 linhas.

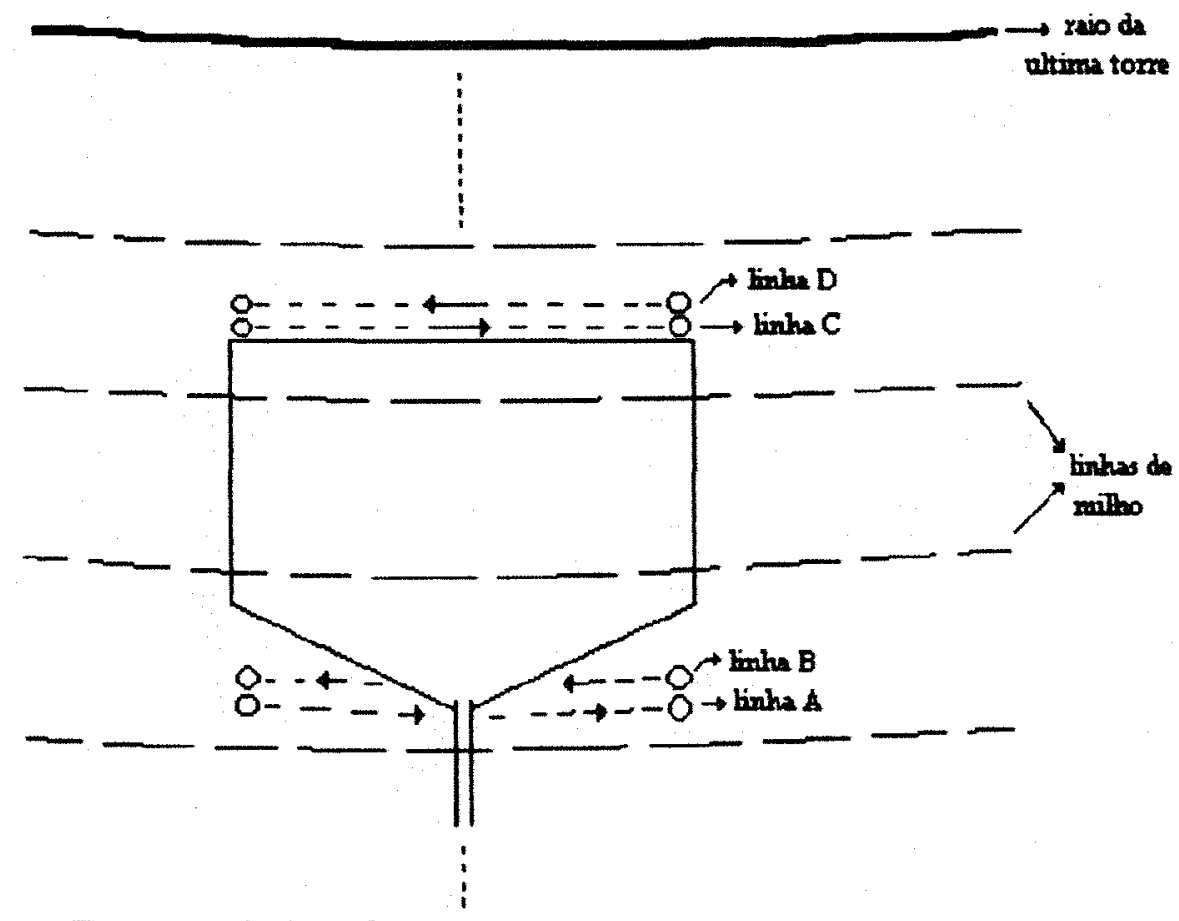

Figura 4 - Esquema da instalação das calhas no campo e disposiç̃o das linhas de coletores e de milho.

O tempo foi contado a partir do momento em que começou a aplicação de água dentro da calha. Novamente para efeito de cálculo, o tempo correspondente a cada intervalo foi considerado como o tempo médio daquele intervalo. 
A taxa de aplicação sob o dossel da cultura foi determinada dispondo-se as linhas de coletores $B$ e $C$ no centro da entrelinha da cultura e as linhas A e D na posição intermediária entre a linha e o centro da entrelinha da cultura, como mostra a Figura 5.

Como as folhas do milho interceptam água e funcionam como coletores, observou-se que as linhas B e C, por estarem logo abaixo da extremidade das folhas, recebem mais água, provocando uma desuniformidade que superestimaria os valores de lâmina coletada. Para minimizar o problema, foi feita uma ponderaçăo atribuindo peso 2 às linhas A e D. Desse modo, foi simulada uma terceira linha de coletores de cada lado da calha, situada na mesma posição que as linhas A e D em relação à linha de plantio da cultura.

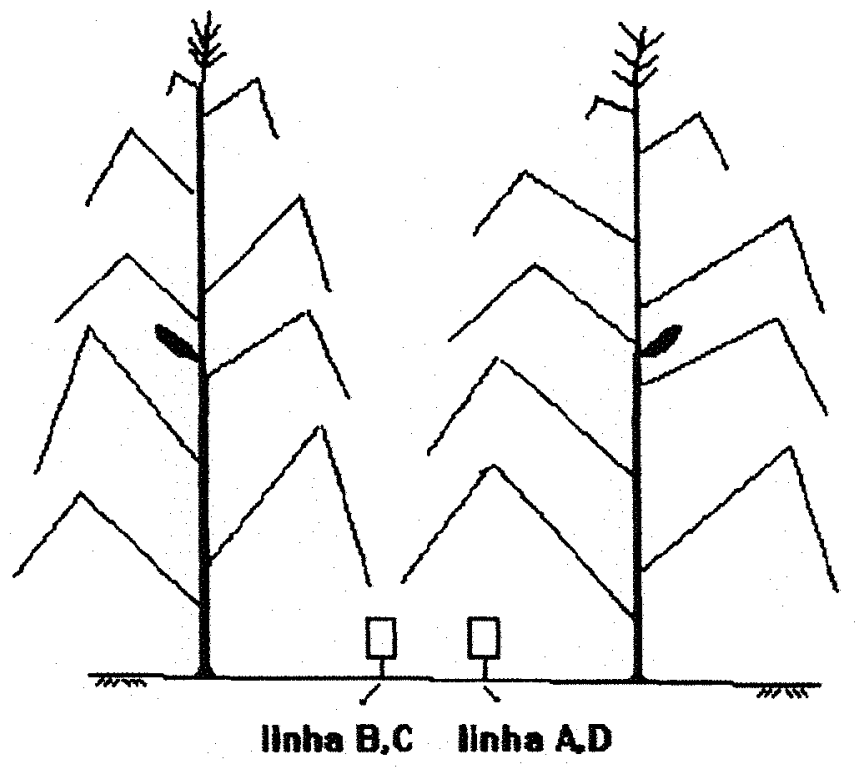

Figura 5 - Esquema da disposição das linhas de coletores em relação às linhas de plantio do milho.

$$
V=\frac{\left[2\left(V_{a}+V_{d}\right)+V_{b}+V_{c}\right]}{6}
$$


em que :

$\mathrm{V}$ - volume ponderado das quatro linhas de coletores $\left(\mathrm{cm}^{3}\right)$

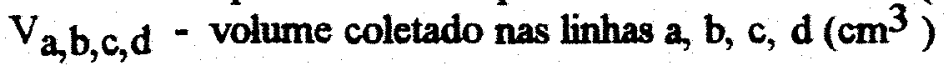

\section{3 - Tratamento dos dados}

Devido à metodologia utilizada, os dados obtidos de lâmina aplicada e escoamento são acumulados e representativos de intervalos de tempo. É necessário um tratamento matemático para desenvolver as funções representativas das taxas de aplicação e escoamento. Foi utilizado o método da "média móvel" para suavizar a curva dos dados acumulados, como recomendado por KELSO \& GILLEY (1983), de acordo com :

$$
X m_{t}=\frac{X_{t-1}+X_{t}+X_{t+1}}{3}
$$

em que :

$X m_{t}$ - valores de lâmina ou escoamento acumulados no tempo $t$, após a utilização da média móvel

$X$ - valores de lâmina ou escoamento acumulados inciais, no tempo $t-1, t$ e $t+1$

Através deste procedimento, o aspecto irregular da curva de dados acumulados foi eliminado. Este procedimento foi repetido 3 vezes, tomando-se o cuidado para não alterar o valor da lâmina total acumulada. $O$ número de vezes em que a operação foi repetida foi denominado "fator de uniformização Fi", onde i é o número de repetições do procedimento.

Após os dados de lâmina acumulada serem submetidos ao tratamento da "média móvel", a taxa de aplicação em cada intervalo foi determinada através de diferenciação numérica:

$$
T A_{t}=\frac{L_{t}-L_{t-1}}{\frac{\Delta t}{60}}
$$


em que :

$\mathrm{TA}_{\mathrm{t}}$ - taxa de aplicação no tempo $t(\mathrm{~mm} / \mathrm{h})$

$L_{t}$ - lâmina aplicada acumulada no tempo $t(\mathrm{~mm})$

$\Delta t$ - intervalo de tempo utilizado na obtenção dos dados (min)

Os dados de escoamento superficial acumulado não foram processados pela média móvel, pelo fato da curva dos dados originais apresentar forma suave e para manter estritamente inalterados os tempos de início e fim do escoamento. A taxa de escoamento em cada intervalo foi obtida pela fórmula:

$$
T E_{t}=\frac{L_{t}-L_{t-1}}{\frac{\Delta t}{60}}
$$

em que :

$\mathrm{TE}_{\mathrm{t}}$ - taxa de escoamento no tempo $t(\mathrm{~mm} / \mathrm{h})$

$\mathrm{L}_{\mathrm{t}}$ - lâmina escoada acumulada no tempo $t(\mathrm{~mm})$

$\Delta t$ - intervalo de tempo utilizado na obtenção dos dados (min)

\section{4 - Caracterização dos emissores utilizados}

$\mathrm{Na}$ execução do trabalho, foram utilizadas as seguintes configurações de emissores :

- aspersor de impacto de média pressão FABRIMAR AO62 ${ }^{1}$, com ângulo de jato de $6^{\circ}$, 2 bocais, regulador de pressão de $280 \mathrm{KPa}$, montado "on top" diretamente na tubulação da lateral

- "spray" fixo de baixa pressão FABRIMAR $A F 2 R^{1}$, com placa difusora plana com 34 estrias, regulador de pressão de $140 \mathrm{KPa}$, montado em pendural de $3 / 4$ " (19 mm) a 2,5 m do solo, alternadamente de cada lado da lateral

-"spray" rotativo modelo "rotator" de baixa pressão NELSON R30 U41, com placa difusora de 4 estrias, regulador de pressão de $140 \mathrm{KPa}$, montado "on top" diretamente na tubulação da lateral

\footnotetext{
${ }^{1}$ A citação do fabricante tem como objetivo apenas informação, não significando sua recomendação pelo autor
} 
A fórmula (12), apresentada por KELLER \& BLIESNER (1990), foi utilizada para calcular a vazão necessária em cada saída :

$$
q_{i}=\frac{2 R_{i} d_{i}}{R_{T}^{2}} Q_{t}
$$

em que :

$q_{i}$ - vazão requerida na saída i $\left(\mathrm{m}^{3} / \mathrm{h}\right)$

$R_{i}$ - distância da saida $i$ ao centro do pivô (m)

$d_{i}$ - metade da distância entre as saídas i-1 e i+1 (m)

$\mathbf{R}_{\mathrm{T}}$ - comprimento total da lateral (m)

$\mathrm{Qt}$ - vazão total do equipamento $\left(\mathrm{m}^{3} / \mathrm{h}\right)$

O diâmetro dos bocais utilizados na simulação, dos emissores que aplicavam água sobre as calhas são mostrados na Tabela 4:

Tabela 4 - Posição em relação ao centro do pivô, vazão requerida e diâmetro dos bocais utilizados na simulação do pivô de $\mathbf{5 0 0} \mathrm{m}$ de raio, na extremidade da lateral.

\begin{tabular}{|c|c|c|c|c|}
\hline \multirow[t]{2}{*}{$\begin{array}{c}\text { Posição da Saída } \\
\text { (m) }\end{array}$} & \multirow[t]{2}{*}{$\begin{array}{c}\text { Varäo } \\
\text { Requerida } \\
\left(\mathrm{m}^{3} / \mathrm{h}\right)\end{array}$} & $\begin{array}{c}\text { Spray Fixo } \\
\text { AF2R }\end{array}$ & $\begin{array}{c}\text { Aspersor de } \\
\text { Impacto } \\
\mathbf{A 0 6 2}\end{array}$ & $\begin{array}{c}\text { Spray Rotativo } \\
\text { R30 U4 }\end{array}$ \\
\hline & & \multicolumn{3}{|c|}{ DLâmetro dos Bocals Utilizados (mm) } \\
\hline 499,0 & 2,08 & 6,8 & $4,6 \times 3,6$ & 7,0 \\
\hline 497,0 & 2,33 & 7,2 & $5,6 \times 3,0$ & 7,4 \\
\hline 494,5 & 2,37 & 7,2 & $5,6 \times 3,0$ & 7,4 \\
\hline 492,4 & 211 & 6,8 & $4,6 \times 3,6$ & 7,0 \\
\hline 490,4 & 3,03 & 8,4 & $5,8 \times 4,4$ & 8,4 \\
\hline \multicolumn{5}{|l|}{ ultima torre } \\
\hline 486,4 & 3,55 & 8,8 & $6,6 \times 4,4$ & 8,8 \\
\hline 483,4 & 2,52 & 7,4 & $5,6 \times 3,4$ & 7,6 \\
\hline 481,4 & 2,06 & 6,8 & $4,4 \times 3,6$ & 7,0 \\
\hline 479,3 & 2,05 & 6,8 & $4,4 \times 3,6$ & 7,0 \\
\hline 477,3 & 1,99 & 6,6 & $4,6 \times 3,4$ & 6,8 \\
\hline 475,3 & 1,98 & 6,6 & $4,6 \times 3,4$ & 6,6 \\
\hline
\end{tabular}




\section{5 - Teste de uniformidade de aplicaçāo}

A uniformidade de aplicação e o perfil de distribuição de água ao longo da lateral do pivô simulado foram avaliadas para cada configuração de emissores utilizada, seguindo-se as normas da ASAE (1991); o CUC foi calculado de acordo com HEERMANN \& HEN (1968) e o CWSD (Coeficiente de Desvio Padrão Ponderado) segundo MAREK et al. (1986). O espaçamento entre coletores foi de $2,0 \mathrm{~m}$, com o pivô sendo operado na velocidade de $76,6 \mathrm{~m} / \mathrm{h}$.

\section{6 - Condução da cultura irrigada}

O preparo do solo utilizado foi o mais empregado em áreas irrigadas para produção de grãos e constituiu-se das seguintes operações:

- duas passadas de grade pesada (disco de $28^{\prime \prime}$ )

- duas passadas de grade niveladora (disco de $22^{\text {p)}}$

A cultura de milho foi conduzida de acordo com as recomendações de REZENDE et al. (1990) para áreas irrigadas. A cultivar utilizada foi o AG 303, híbrido duplo precoce. O plantio foi efetuado em 14/11/93, com plantadeira de sulcador de disco duplo, espaçamento entre linhas de $1,0 \mathrm{~m}, 8,0$ sementes por metro linear, em linhas paralelas ao deslocamento da última torre (conforme figura 4). $O$ fertilizante utilizado foi 0 04-14-08 (570 Kg/ha).O contrôle de ervas daninhas fơ feito através de herbicida de pré emergência (Atrazine, $2,5 \mathrm{Kg}$ i.a/ha), para evitar a necessidade de cultivos mecânicos, e portanto, a movimentação do solo. A germinação ocorreu em $20 / 11 / 93$ e foi feito um desbaste para se estabelecer um stand de 60.000 plantas/ha. A adubação com $\mathrm{N}$ em cobertura foi de $160 \mathrm{Kg} / \mathrm{ha}$, parcelado em duas vezes. 


\section{7 - Lâminas de irrigação e umidade do solo}

As lâminas brutas utilizadas nos testes foram de 6,5 e $27,3 \mathrm{~mm}$, de acordo com a vazão e velocidade de deslocamento do equipamento; considerando uma eficiência potencial de aplicação de $90 \%$, as lâminas líquidas seriam de 5,9 e $24,6 \mathrm{~mm}$, aproximadamente; a primeira corresponde a uma lâmina de reposição diária, típica de pivô central. Considerando que diferentes lâminas por irrigação correspondem a diferentes umidades do solo no momento da irrigação, baseando-se na retenção de água pelo solo, calculou-se a umidade na qual as lâminas aplicadas elevariam o solo à capacidade de campo, assumindo que a profundidade do sistema radicular é de $0,30 \mathrm{~m}$ e a capacidade de campo ocorre na tensão de $0,33 \mathrm{~atm}(32 \mathrm{KPa})$ :

$$
\begin{aligned}
& L=\left(\theta_{c c}-\theta\right) Z_{e f} \\
& \theta=\theta_{c c}-\frac{L}{Z_{e f}}
\end{aligned}
$$

em que :

L - lâmina híquida a ser aplicada para elevar o solo à capacidade de campo (mm)

$\theta$ - umidade atual do solo $\left(\mathrm{cm}^{3} / \mathrm{cm}^{3}\right)$

$\theta_{c c}$ - umidade do solo na capacidade de campo $\left(0,3192 \mathrm{~cm}^{3} / \mathrm{cm}^{3}\right)$

$\mathrm{Z}_{\text {ef }}$ - profundidade efetiva do sistema radicular $(300 \mathrm{~mm})$

Nestas condições, para as lâminas de 5,9 e $24,6 \mathrm{~mm}$, a umidade do solo no momento da irrigação seria de, respectivamente, 22,8 e $18,3 \%$ em peso.

\section{8 - Execução dos ensajos de campo}

Os testes foram realizados de modo a representar as condições do meio agrícola (planta e solo) ao longo do ciclo da cultura do milho, que foi divido em 3 estádios: 
1 - inicial (estabelecimento da cultura) : M1

2 - intermediário (desenvolvimento vegetativo) : M2

3 - final (granação) : M3

No dia da realização dos ensaios, foi feita a determinação do IAF nos estádios 2 e 3, para caracterização da cobertura vegetal. Cuidados especiais foram tomados para manter as plantas de milho intactas e a superficie do solo sem movimentação na região das calhas. A umidade do solo foi monitorada na camada de $\mathbf{0}$ a $30 \mathrm{~cm}$ pelo método das pesagens, para fornecer o resultado imediato, e aferida pelo método da estufa. Um pluviômetro foi instalado próximo da área experimental, para medição da precipitação pluviométrica.

A velocidade de deslocamento da última torre foi determinada nas regulagens de $100,80,60,40$ e $20 \%$ do relé percentual, sendo ajustada a seguinte função, que apresentou $r^{2}=0,999$ :

$$
V(R)=-6,717+1,308 R+1,613 \times 10^{-2} R^{2}-1,146 \times 10^{-4} R^{3}
$$

em que :

V - velocidade de deslocamento da última torre $(\mathrm{m} / \mathrm{h})$

$\mathrm{R}$ - regulagem do relé percentual (\%)

Os testes foram realizados nos três estádios do milho, com os três emissores, utilizando-se as duas lâminas de irrigą̧̃̃o, com o solo na umidade de 18 ou 23 $\%$ em peso. O emissor "rotator" foi utilizado nos pontos 1 a 4, o" spray" nos pontos 5 a $8 \mathrm{e}$ o aspersor de impacto nos pontos 9 a 12. Os dispositivos de coleta de lâmina e escoamento foram montados em cada conjunto de quatro pontos e o pivô, equipado com o tipo de emissor correspondente, foi operado nas velocidades de 158 e $38 \mathrm{~m} / \mathrm{h}$, para aplicar as lâminas aproximadas de 6 e $25 \mathrm{~mm}$. Após a passagem sobre os quatro pontos, o pivô foi desligado, os emissores do último vão e balanço substitúdos e os dispositivos de coleta de lâmina e escoamento montados nas quatro posições seguintes e o teste recomeçado. 


\section{9 - Determinação da curva de infiltração de água no solo}

O teste de infiltração foi realizado entre a primeira e segunda gradagem niveladora, utilizando-se como emissor o aspersor de impacto, que devido ao seu maior alcance, permite longo tempo de aplicação e, portanto, permite ao solo aproximar-se da velocidade de infiltração básica. Após o preparo, a superficie do solo foi uniformizada manualmente nos 12 pontos de medição, para minimizar o armazenamento superficial; a seguir, foi aplicada uma lâmina de irrigação de $90 \mathrm{~mm}$, mais $72 \mathrm{~mm}$ de chưva, acumulando $162 \mathrm{~mm}$, para provocar o selamento superficial e representar a condição de infiltração média do solo durante o ciclo da cultura.

A curva de infiltração foi determinada a partir da diferença entre taxa de aplicação e taxa de escoamento. Os dados de lâmina aplicada e escoamento acumulados foram submetidos ao processo da "média móvel" por três vezes (F3). Após este procedimento, os valores de taxa de aplicação e taxa de escoamento em cada intervalo de tempo foram obtidos por diferenciação numérica. Este procedimento foi utilizado por KELSO \& GILLEY (1983). A taxa de infiltração em cada intervalo foi obtida por:

$$
T I_{t}=T A_{t}-T E_{t}
$$

em que :

$T(t)$ - taxa de infiltração no instante $t(\mathrm{~mm} / \mathrm{h})$

Foram realizados dois testes, com o solo nas umidades de 18 e $23 \%$ em peso (correspondentes às lâminas de 25 e $6 \mathrm{~mm}$, respectivamente), com a última torre do pivô sendo movimentada nas velocidades de, respectivamente, 25 e $64 \mathrm{~m} / \mathrm{h}$. Após os testes de infiltração, o solo foi gradeado (uma passada de grade niveladora) para quebrar o selamento superficial e efetuado o plantio do milho. 


\section{4 - RESULTADOS E DISCUSSÃO}

A Tabela 5 mostra os valores de lâmina acumulada, proveniente de chuva e irrigação, durante a execução do experimento. Os dados são referentes ao período decorrido até a maturação fisiológica, que se deu aos 112 dias.

Tabela 5 - Valores de lâmina d'água acumulados durante a execução do experimento, proveniente de chuva (C) ou irrigação (I).

\begin{tabular}{|c|c|c|c|}
\hline Dha & $\begin{array}{c}\text { Lâmha } \\
\mathbf{m m}\end{array}$ & $\begin{array}{c}\text { Chuva ca } \\
\text { Irrigacão }\end{array}$ & $\begin{array}{c}\text { Acumulado } \\
\mathbf{m m}\end{array}$ \\
\hline $16 / 11$ & 14 & $\mathrm{I}$ & 14 \\
\hline $17 / 11$ & 7 & $\mathrm{I}$ & 21 \\
\hline $19 / 11$ & 7 & $\mathrm{C}$ & 28 \\
\hline $21 / 11$ & 16 & $\mathrm{I}$ & 44 \\
\hline $22 / 11$ & 12 & $\mathrm{C}$ & 56 \\
\hline $25 / 11$ & 9 & $\mathrm{C}$ & 65 \\
\hline $26 / 11$ & 30 & $\mathrm{C}$ & 95 \\
\hline $02 / 12$ & 25 & $\mathrm{I}^{\mathrm{g}}$ & 120 \\
\hline $04 / 12$ & 17 & $\mathrm{C}$ & 137 \\
\hline $09 / 12$ & 6 & $\mathrm{I}^{\mathrm{O}}$ & 143 \\
\hline $12 / 12$ & 22 & $\mathrm{C}$ & 165 \\
\hline $17 / 12$ & 7 & $\mathrm{C}$ & 172 \\
\hline $22 / 12$ & 22 & $\mathrm{C}$ & 194 \\
\hline $04 / 01$ & 14 & $\mathrm{C}$ & 208 \\
\hline $06 / 01$ & 24 & $\mathrm{I}^{\mathrm{C}}$ & 232 \\
\hline $09 / 01$ & 48 & $\mathrm{C}$ & 280 \\
\hline $13 / 01$ & 4 & $\mathrm{I}^{\mathrm{d}}$ & 284 \\
\hline
\end{tabular}

\begin{tabular}{|c|c|c|c|}
\hline DAa & $\begin{array}{c}\text { Lamina } \\
\mathrm{mm}\end{array}$ & $\begin{array}{l}\text { Chuva ou } \\
\text { Imigapão }\end{array}$ & $\begin{array}{c}\text { Acrimalado } \\
\mathrm{mm}\end{array}$ \\
\hline $19 / 01$ & 9 & I & 293 \\
\hline $19 / 01$ & 6 & C & 299 \\
\hline $23 / 01$ & 8 & I & 307 \\
\hline $25 / 01$ & 15 & $\bar{C}$ & 322 \\
\hline $28 / 01$ & 30 & C & 352 \\
\hline $29 / 01$ & 15 & C & 367 \\
\hline $03 / 02$ & 6 & $\mathrm{I}^{\mathrm{e}}$ & 373 \\
\hline $06 / 02$ & 30 & C & 403 \\
\hline $09 / 02$ & 29 & C & 432 \\
\hline $12 / 02$ & 15 & $\bar{C}$ & 447 \\
\hline $13 / 02$ & 10 & C & 459 \\
\hline $15 / 02$ & 5 & C & 462 \\
\hline $20 / 02$ & 6 & C & 468 \\
\hline 22102 & 14 & C & 482 \\
\hline $03 / 03$ & 19 & C & 501 \\
\hline $04 / 03$ & 9 & $\mathrm{C}$ & 510 \\
\hline $07 / 03$ & 2 & C & 512 \\
\hline
\end{tabular}
a ensaio com o milho no estádio 1 e lâmina de $25 \mathrm{~mm}$
b ensaio com o milho no estádio 1 e lâmina de $6 \mathrm{~mm}$
c ensaio com o mitho no estádio 2 e lâmina de $25 \mathrm{~mm}$
d ensaio com o milho no estádio 2 e lâmina de $6 \mathrm{~mm}$
e ensaio com o milho no estádio 3 e lâmina de $6 \mathrm{~mm}$ 
Pela tabela 5 , observa-se que não foi realizado o ensaio com o milho no estádio 3 e lâmina de 25 mm, devido às condições climáticas. A precipitação pluviométrica manteve o solo sempre com umidade acima de $18 \%$ até o final do ciclo do milho.

Os intervalos de tempo utilizados, em função da lâmina e do emissor, e o diâmetro de alcance medido no campo são apresentados na Tabela 6 :

Tabela 6 - Valores dos intervalos de tempo utilizados nos ensaios em função do emissor e lâmina aplicada.

\begin{tabular}{|c|c|c|}
\hline \multirow{3}{*}{ EMISSOR } & LAMINA & $(\mathbf{m m})$ \\
\hline & 6 & 25 \\
\hline & Intervalo de & Tempo (min) \\
\hline Impacto & 1,5 & 3,0 \\
\hline Rotator & 1,0 & 2,0 \\
\hline "spray" & 1,0 & 1,5 \\
\hline
\end{tabular}

A Figura 6 esquematiza o padrão molhado e diâmetro de alcance produzido pelas três configurações de emissores utilizadas.

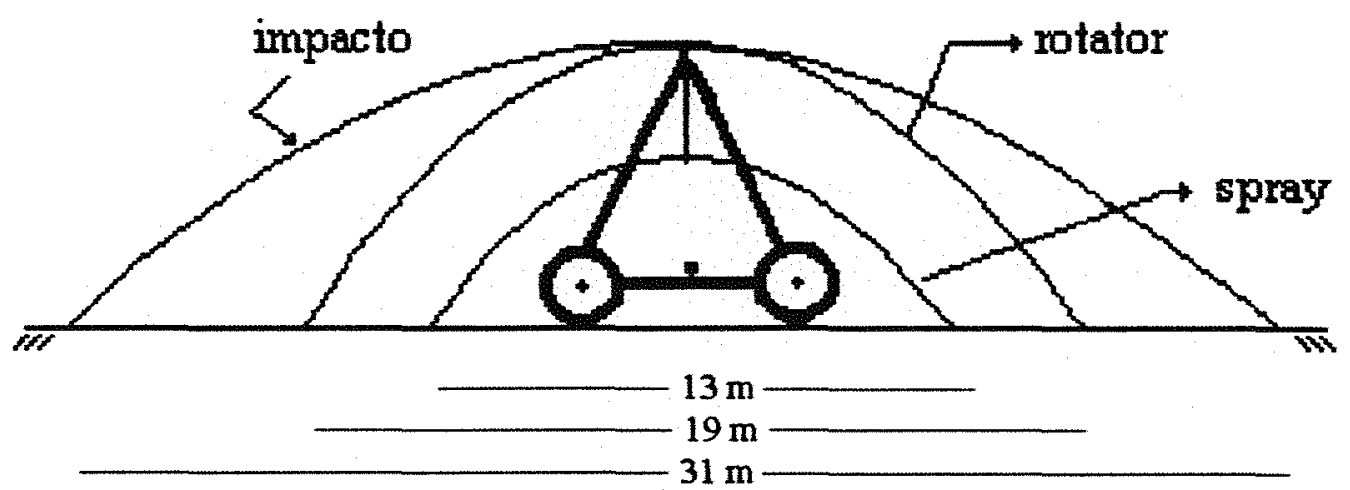

Figura 6 - Padrão molhado e diâmetro de alcance em função do tipo de emissor e de montagem. 
A caracterização das plantas de milho em função do estádio de desenvolvimento, na época da realização dos ensaios, encontra-se na Tabela 7 :

Tabela 7 - Caracterização das plantas de milho na data dos ensaios.

\begin{tabular}{|c|c|c|c|}
\hline ESTÁDIO & $\begin{array}{c}\text { IDADE } \\
\text { dias }\end{array}$ & $\begin{array}{c}\text { ALTURA } \\
\text { m }\end{array}$ & IAF \\
\hline Milho 1 & 15 & 0,25 & - \\
\hline Milho 2 & 50 & 1,80 & 3,95 \\
\hline Milho 3 & 75 & 2,45 & 4,09 \\
\hline
\end{tabular}

\section{1 - Uniformidade de aplicação}

Os resultados do ensaio de uniformidade do pivô simulado encontram-se na Tabela 8 e o gráfico do perfil de distribuição de água na Figura 7. A velocidade da última torre durante o ensaio foi de $76,6 \mathrm{~m} / \mathrm{h}$, o que resultaria numa lâmina bruta teórica de $13,2 \mathrm{~mm}$, calculada pela vazão de projeto de $260,8 \mathrm{~m}^{3} / \mathrm{h}$. Como não foi feita a determinação da vazão do equipamento na região da simulação, a eficiência de aplicação potencial foi calculada teoricamente.

Tabela 8 - Resultados do ensaio de uniformidade do pivô simulado, utilizando as três configurações de emissores

\begin{tabular}{|l|c|c|c|c|}
\hline \multicolumn{1}{|c|}{ EMISSOR } & CUC & CUSW & LÂmma & Eficlôncla \\
\hline & $\%$ & $\%$ & Médla & $\%$ \\
\hline aspersor de impacto & 89,9 & 87,9 & 11,7 & 88,6 \\
\hline "spray" rotativo & 94,4 & 92,7 & 12,0 & 90,9 \\
\hline "spray" fixo & 88,4 & 84,6 & 11,6 & 87,9 \\
\hline
\end{tabular}

Os valores de CUC e CUSW encontrados para os três emissores estão dentro da faixa de valores encontrados em equipamentos bem projetados e funcionando adequadamente. Os altos valores encontrados podem ser explicados pelo fato de se estar na extremidade da lateral (último vão e balanço final), cơm todas as saídas sendo 
utilizadas, resultando numa pequena distância entre emissores, e portanto, aumentando a sobreposição. Outro fato que favorece esta alta uniformidade é por se estar próximo à torre guia, onde o efeito da desuniformidade de deslocamento é menor. HANSON et al. (1986) encontraram valores de CUC de $90 \%$ na extremidade e $75 \%$ na metade da lateral, num pivô equipado com "sprays". Os menores valores do "spray" fixo são devido à menor sobreposição, provocada pelo menor raio de alcance e por estar mais próximo do solo (montado em pendurais) e pelo fato do emissor ser o único que não apresenta movimento rotativo. Os maiores valores do "spray" rotativo se devem ao movimento giratório suave e constante da placa difusora, que ainda fraciona o fluxo em quatro jatos, permitindo grande superposição. Valores semelhantes foram encontrados pelo IPT (1993) e TEIXEIRA (1992) para este emissor. BRIDI (1984) e COTRIM (1988) encontraram valores de 86,6 e 86,7 \%, para pivôs com aspersores de impacto e "sprays", respectivamente. Observa-se que os "sprays" de baixa pressão conseguem uniformidades comparáveis às dos aspersores de média e alta pressão, como afirmado por SILVA (1989) e Toyamani et al ${ }^{1}$, citados por REZENDE (1992), chegando a ser superior no caso dos "sprays" giratórios ou "rotator".

Os menores valores do CUSW em relação ao CUC mostram que este coeficiente é menos sensivel às variações da lâmina aplicada, como observado por TEIXEIRA (1992). Este autor encontrou CUC de 93,6 e 87,6 \% e CUSW de 89,7 e 81,5 $\%$ para "spray" rotativo sobre a lateral e "spray" fixo em pendural a $2,0 \mathrm{~m}$ do solo, respectivamentes.

No aspersor de impacto, observa-se um aumento acentuado da lâmina aplicada na distância aproximada de $490 \mathrm{~m}$, onde se localiza a última torre. Isto foi provocado pelo choque do jato do aspersor com a caixa elétrica de contrôle da última

\footnotetext{
1 TOOYAMANI, K.P.; NORUM, D.I.; DUBETS, S. Application Rates and Uniformity under Center Pivot Sprinkder Irrigation Systems using Spray Nozzles. Canadian Agricultural Engineering. 29 : p. 149.1987
} 
torre, resultando numa maior precipitação nessa região. Para solucionar o problema, devese instalar os aspersores adjacentes às torres em tubos de subida de 0,5 m.

As diferenças de lâmina média ponderada e eficiência de aplicação podem ser explicadas pela diferença de vazão fornecida pelas configuraçōes de emissores utilizadas, que não são exatamente iguais. A eficiência potencial de aplicação foi pouco influenciada pelo clima, porque os testes foram conduzidos em períodos de baixa demanda evaporativa da atmosfera e baixa velocidade do vento, conforme normas da ASAE (1991).

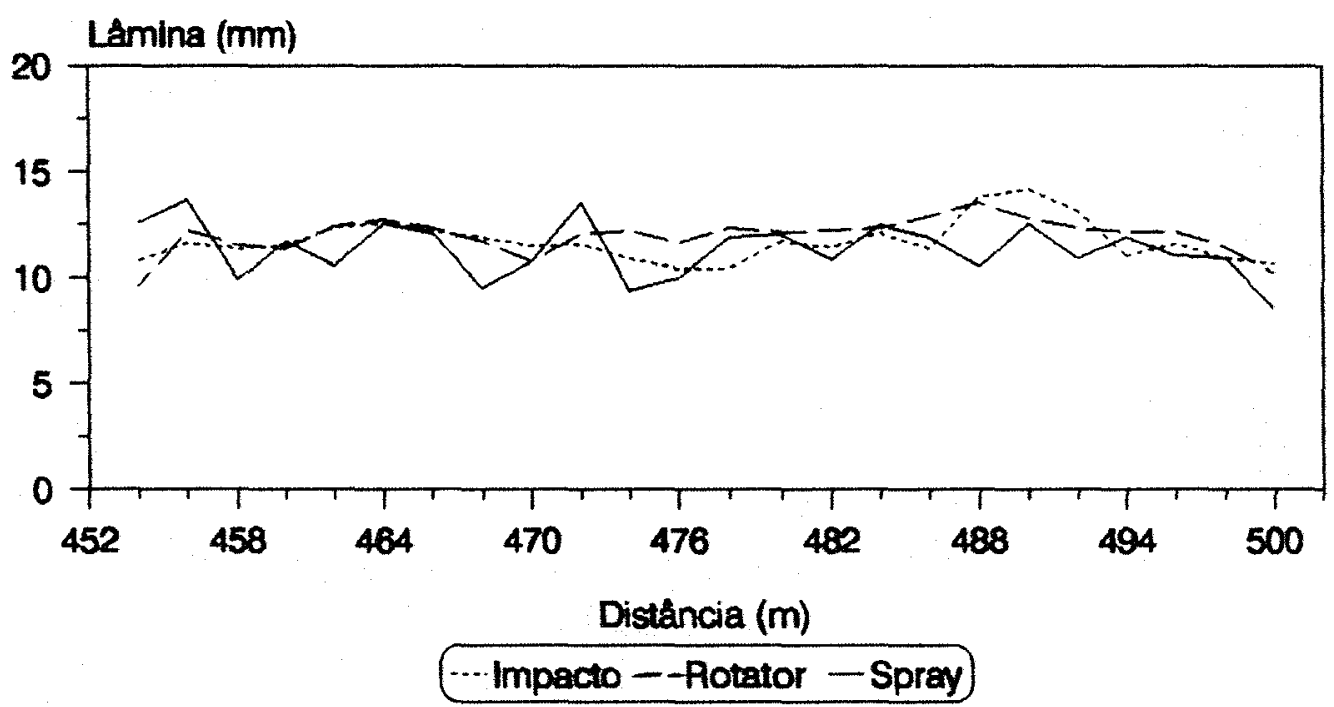

Figura 7 - Perfil de distribuição de água do pivô simulado.

\section{2 - Tara de aplicação e escoamento ao longo do ciclo da cultura}

As curvas de aplicação e escoamente acumulados obtidos no campo, são exemplificadas na Figura 8, para o aspersor de impacto aplicando lâmina de 6 e $25 \mathrm{~mm}$, com o milho no estádio 1. Observa-se o efeito da utilização da média móvel para suavizar a curva de aplicação acumulada. A curva de aplicação F0 representa os dados originais, tal 
como foram obtidos no campo. Após a aplicação da média móvel por 3 vezes, foi obtida a curva de aplicação F3. A partir destas curvas de dados acumulados, foram obtidas as curvas de taxa de aplicação e escoamento, por diferenciação numérica.
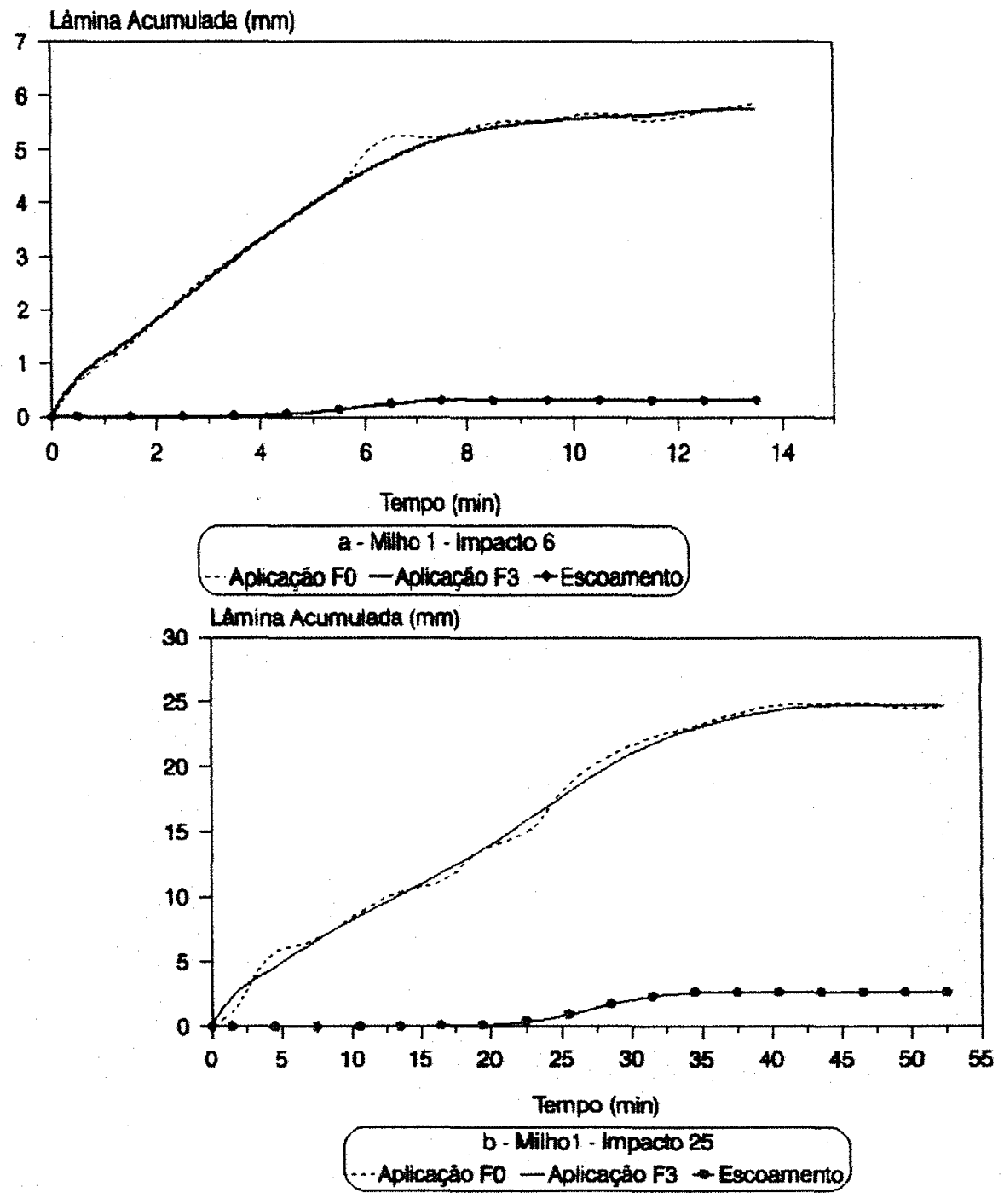

Figura 8 - Exemplo de curva de dados acumulados de aplicação e escoamento, antes e após a utilização da média móvel.

A Figura 9 mostra as curvas teóricas de aplicação na extremidade do pivô simulado, para as lâminas de 6 e $25 \mathrm{~mm}$, obtidas através da equação (1). Pela figura 
pode-se observar que a taxa máxima de aplicação independe da lâmina aplicada, como afirmam KELLER \& BLIESNER (1990).
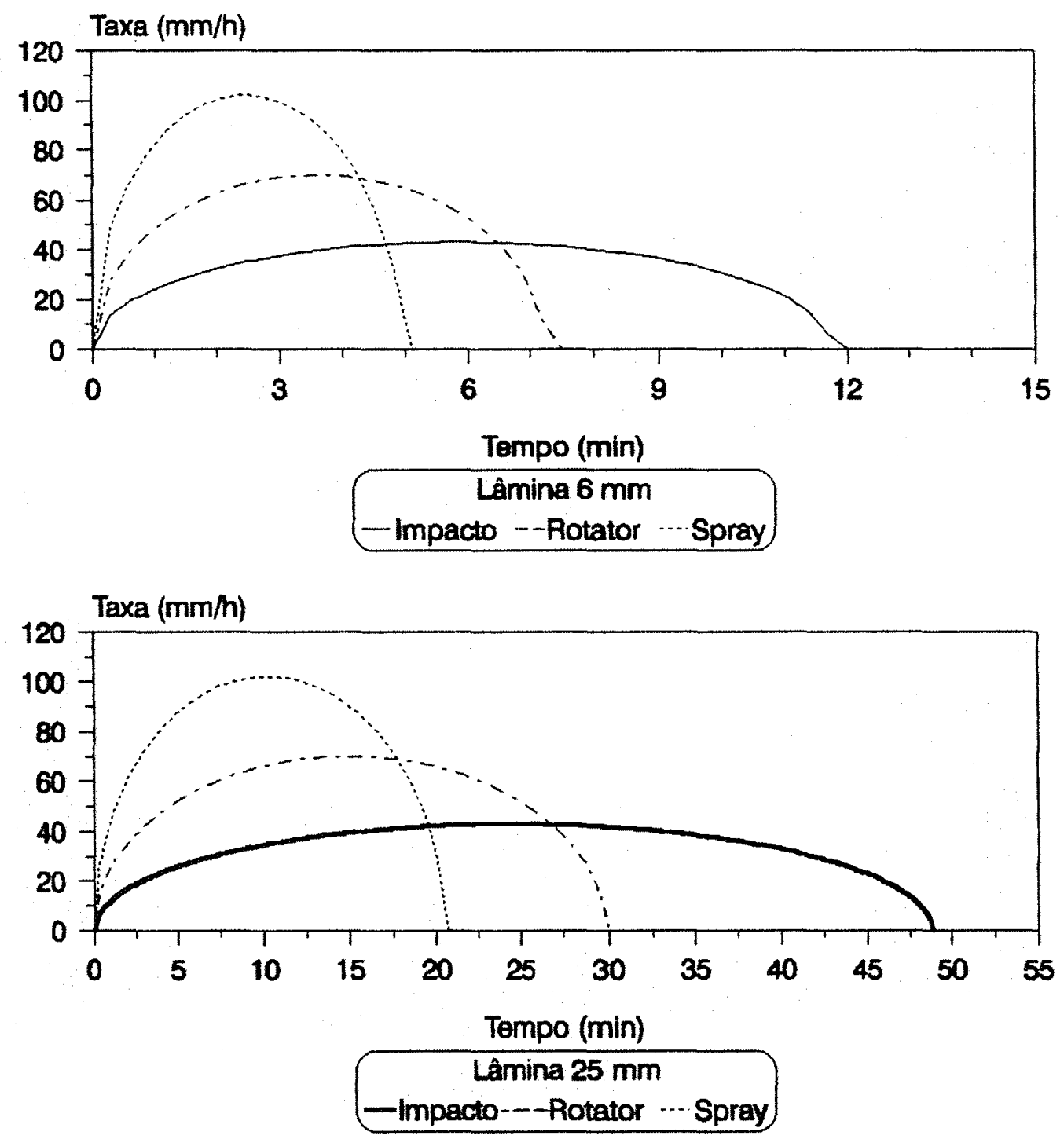

Figura 9 - Taxa e tempo de aplicação teóricos segundo a equação (1) em função da lâmina aplicada e emissor utilizado.

A Figura 10 mostra os gráficos da taxa de aplicação e de escoamento, para os ensaios com o milho no estádio 1 e lâmina de $6 \mathrm{~mm}$. Na figura 10-a, para o aspersor de impacto, a taxa de aplicação máxima se aproximou da teórica e a baixa taxa no final da aplicação é devido à neblina provocada pelo equipamento, prolongando o 
tempo de aplicação teórico. Fenômeno semelhante foi observado por KELSO \& GLLEY (1983). A figura 10-b, para o "rotator", mostra que a taxa máxima se aproximou da teórica e o tempo de aplicação foi superior ao teórico. A figura 10-c mostra que a taxa máxima para o "spray" fixo foi subestimada, provavelmente devido ao intervalo de tempo utilizado ser inadequado em relação ao tempo de aplicação, que é muito curto. O tempo de aplicação superou o teórico. A curva de aplicação do "spray" é semelhante a do rotator, porque o tempo de aplicação é pequeno em relação ao intervalo de tempo utilizado. $O$ escoamento iniciou primeiro para o "spray", devido a sua maior taxa de aplicação.

A Figura 11 mostra o ensaio com o milho no estádio 1 e aplicação da lâmina de $25 \mathrm{~mm}$. A taxa máxima e o tempo de aplicação para o aspersor de impacto aproximaram-se dos teóricos. Novamente observa-se uma assimetria provocada pela neblina. Na figura 11-b, para o "rotator", a taxa máxima e o tempo de aplicação aproximaram-se do teórico. A taxa máxima de aplicação para o "spray" fixo (fig 11-c) foi melhor estimada, porque o tempo de aplicação aumentou e o intervalo de tempo passou a ser mais adequado. Observa-se que ocorreu escoamento mesmo após o término da aplicação. O tempo de aplicação observado superou o teórico. Para os três emissores, observa-se uma depressão na taxa de aplicação, que é devido à passagem da lateral em velocidade lenta sobre os coletores. Comportamento semelhante foi observado por KELSO \& GIILEY (1983). Quando a velocidade é rápida, este efeito näo é perceptível, como mostra a figura 10 ,

A figura 12 mostra os ensaios com o mitho no estádio 2 e lâmina de 6 mm. Observa-se que a presença do dossel vegetativo reduziu a taxa máxima de aplicação principalmente com o aspersor de impacto. Ocorreu escoamento superficial com o "spray", mesmo após o término da aplicação. 


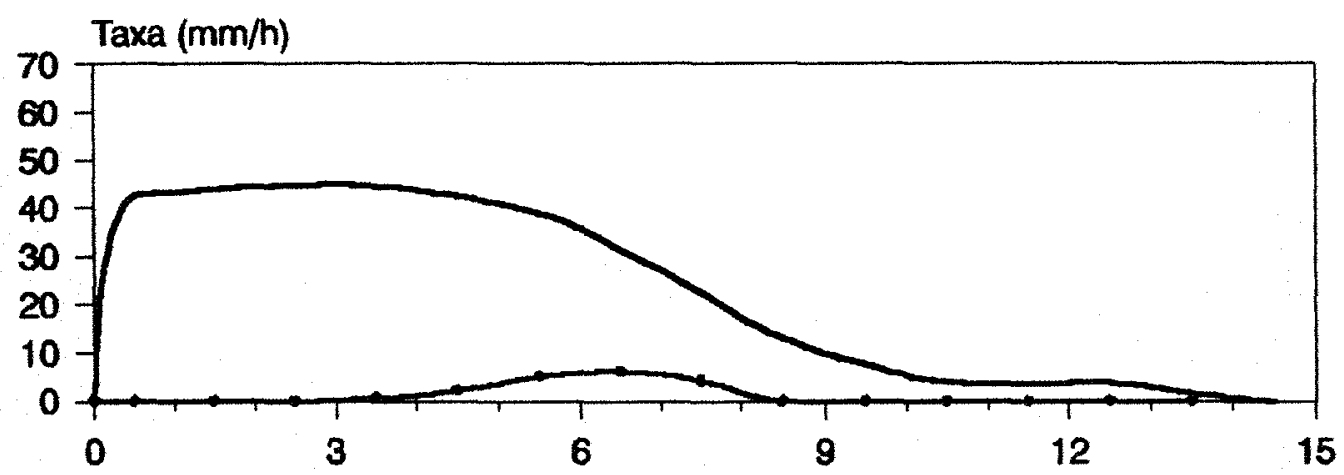

Tempo (min)
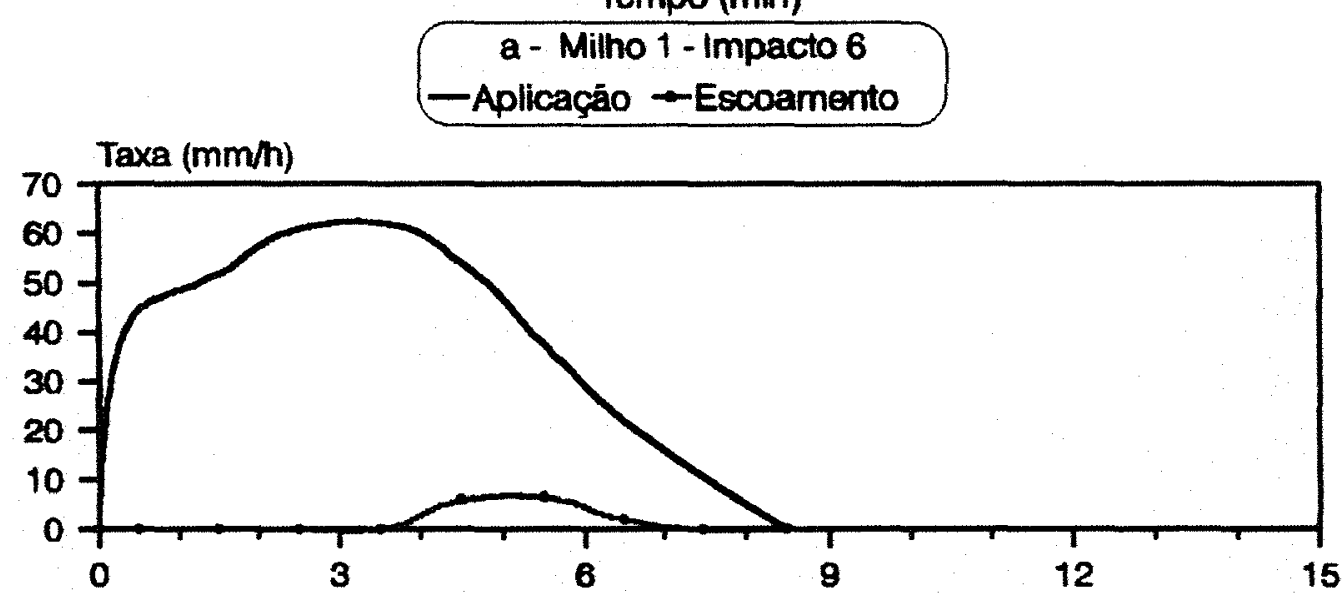

Tempo (min)
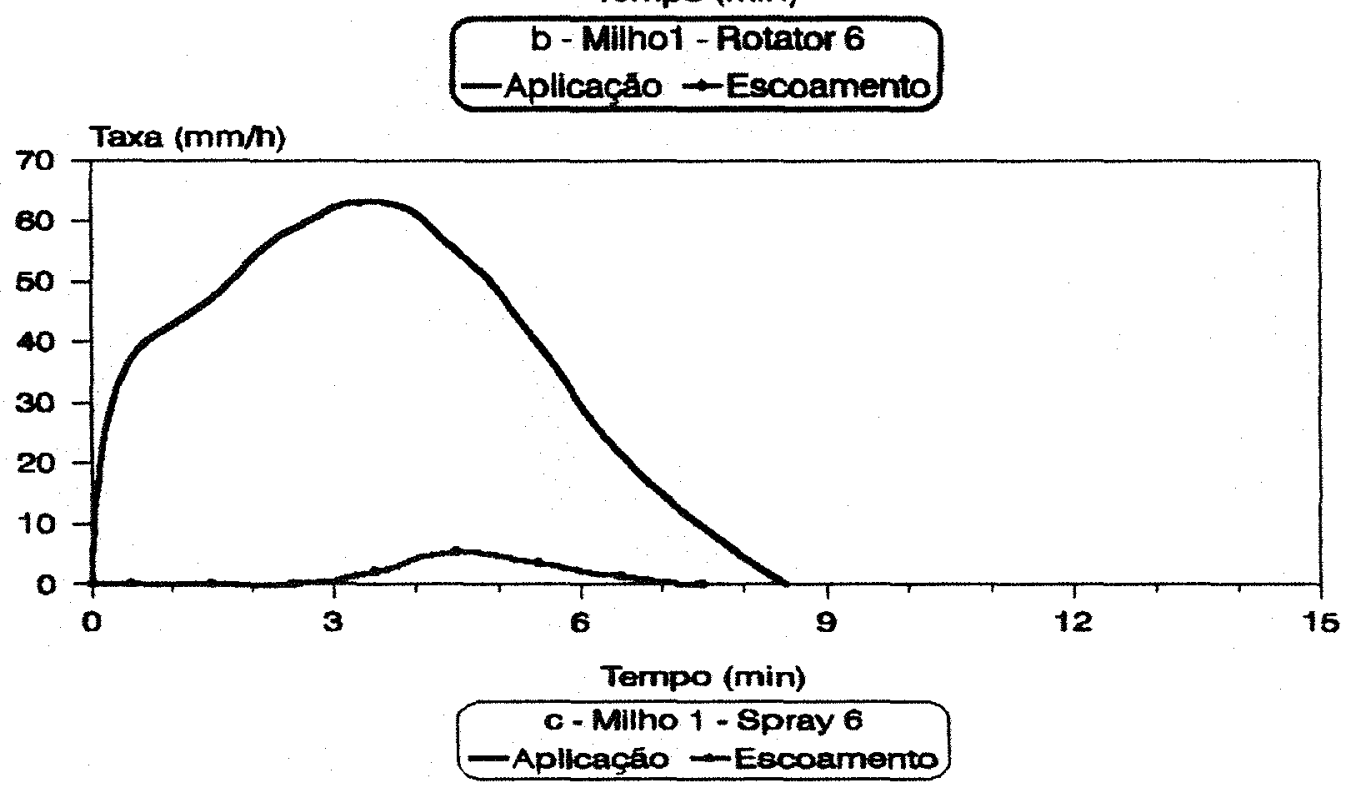

Figura 10 - Curvas de taxa de aplicação e escoamento para milho 1 e lâmina $6 \mathrm{~mm}$ 

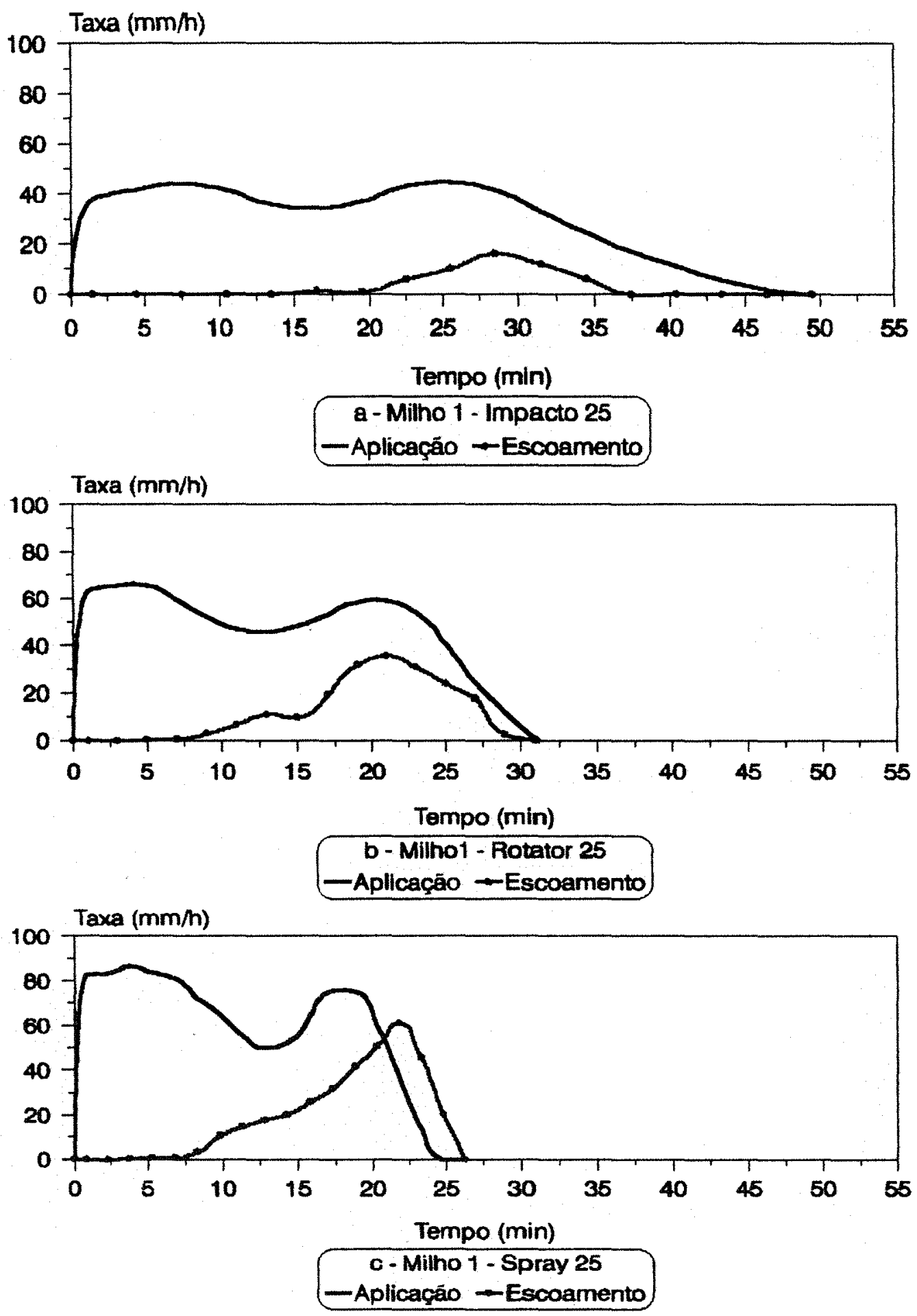

Figura 11 - Curvas de taxa de aplicação e escoamento para milho 1 e lâmina $25 \mathrm{~mm}$ 
$\operatorname{Taxa}(\mathrm{mm} / \mathrm{h})$

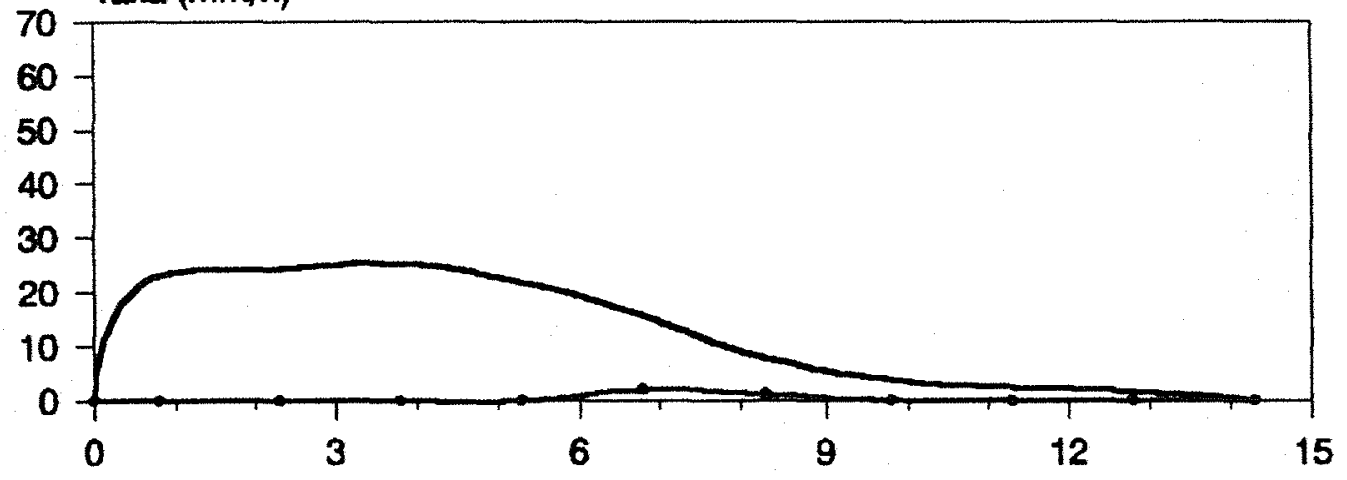

Tempo (min)

a - Milho 2 - Impacto 6

-Aplicação -Escoamento

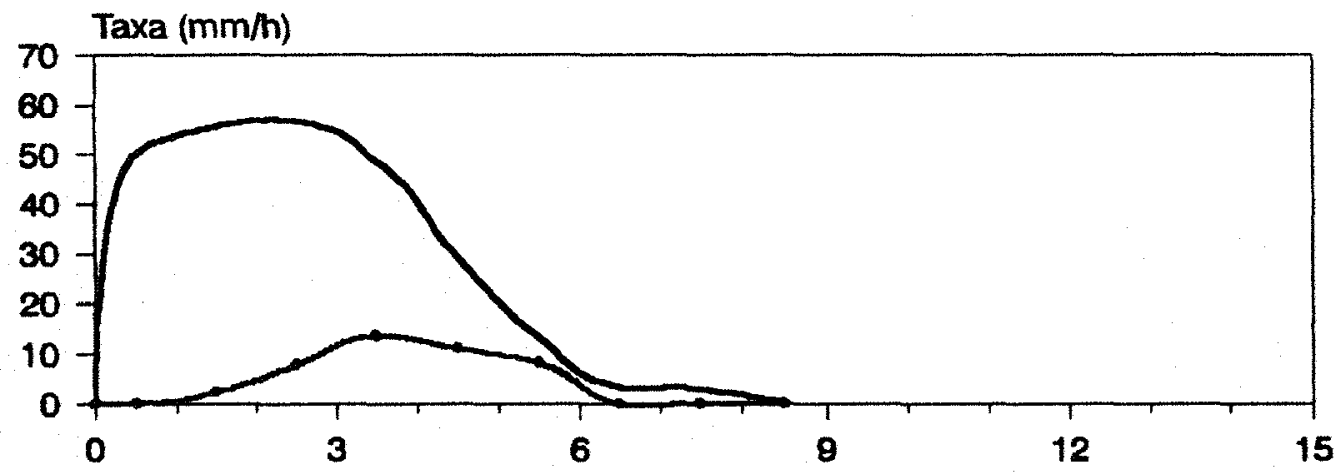

Tempo (min)
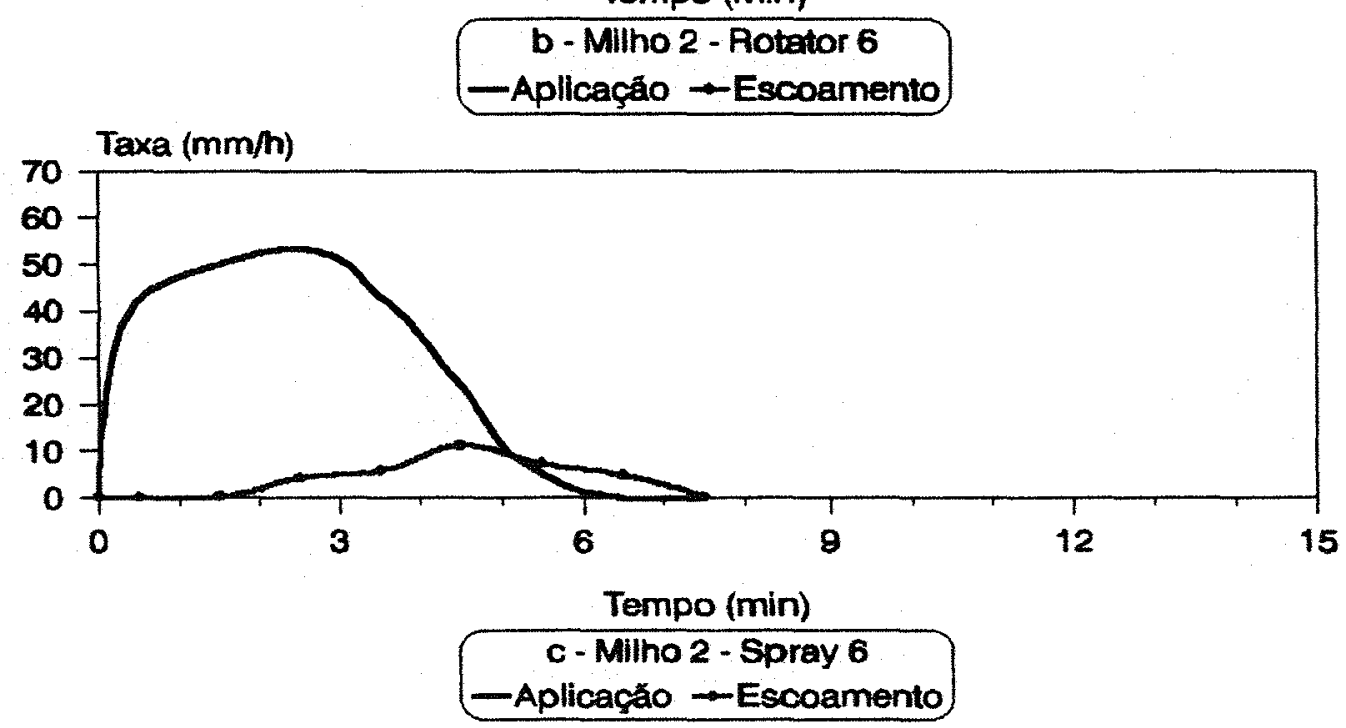

Figura 12 - Curvas de taxa de aplicação e escoamento para milho 2 e lâmina $6 \mathrm{~mm}$ 
A figura 13 mostra os ensaios com o milho no estádio 2 e lâmina de 25 mm. Observa-se que, para os três emissores, a redução da taxa máxima foi menos significativa que no ensaio com lâmina de $6 \mathrm{~mm}$. Isto provavelmente se deve à retenção foliar pelo dossel vegetativo, que passa a ser menos significativa. Observa-se pela figura 13-c, que no "spray" fixo, a taxa de escoamento chegou a ser maior que a taxa de aplicação por um periodo de aproximadamente 7 minutos.

A figura 14 mostra os ensaios para o milho no estádio 3 e lâmina de $6 \mathrm{~mm}$. O comportamento da taxa de aplicação é bem semelhante aos ensaios no estádio anterior. As curvas de taxa de escoamento mostram que o volume escoado foi menor para os três emissores, em relação ao milho no estádio 2 , contrariando as afirmações de autores com EVANS (1980) e PRUSTKI et al (1993). Como a retenção foliar e o IAF foram praticamente os mesmos, provavelmente isto se deve a um aumento na capacidade de infiltração de água no solo, provocada pela decomposição de raízes, aumentando a porosidade, e/ou pela alteração na arquitetura da planta, mesmo apresentando praticamente o mesmo LAF. No estádio milho 2, a maior parte das folhas está na região basal da planta, que apresenta então um aspecto aproximadamente cônico. No estádio milho 3, o desenvolvimento da planta e o carreamento de nutrientes para a espiga provoca a morte das folhas da parte basal da planta e a maior parte das folhas passa a se localizar na metade até o ápice da planta, que apresenta então o aspecto de um cone invertido; a altura de plantas neste estádio também era maior em $0,65 \mathrm{~m}$ em relação ao milho 2 . Esta mudança na arquitetura pode afetar a maneira como a água atinge o solo, embora isto não tenha sido detectado pela metodologia de determinação da curva da taxa de aplicação. Para detectar este fenômeno, provavelmente seria necessário determinar se houve alteração no fhuxo de água que escorre pelo caule das plantas, e no volume da água retido pelas inserções das folhas no caule. 

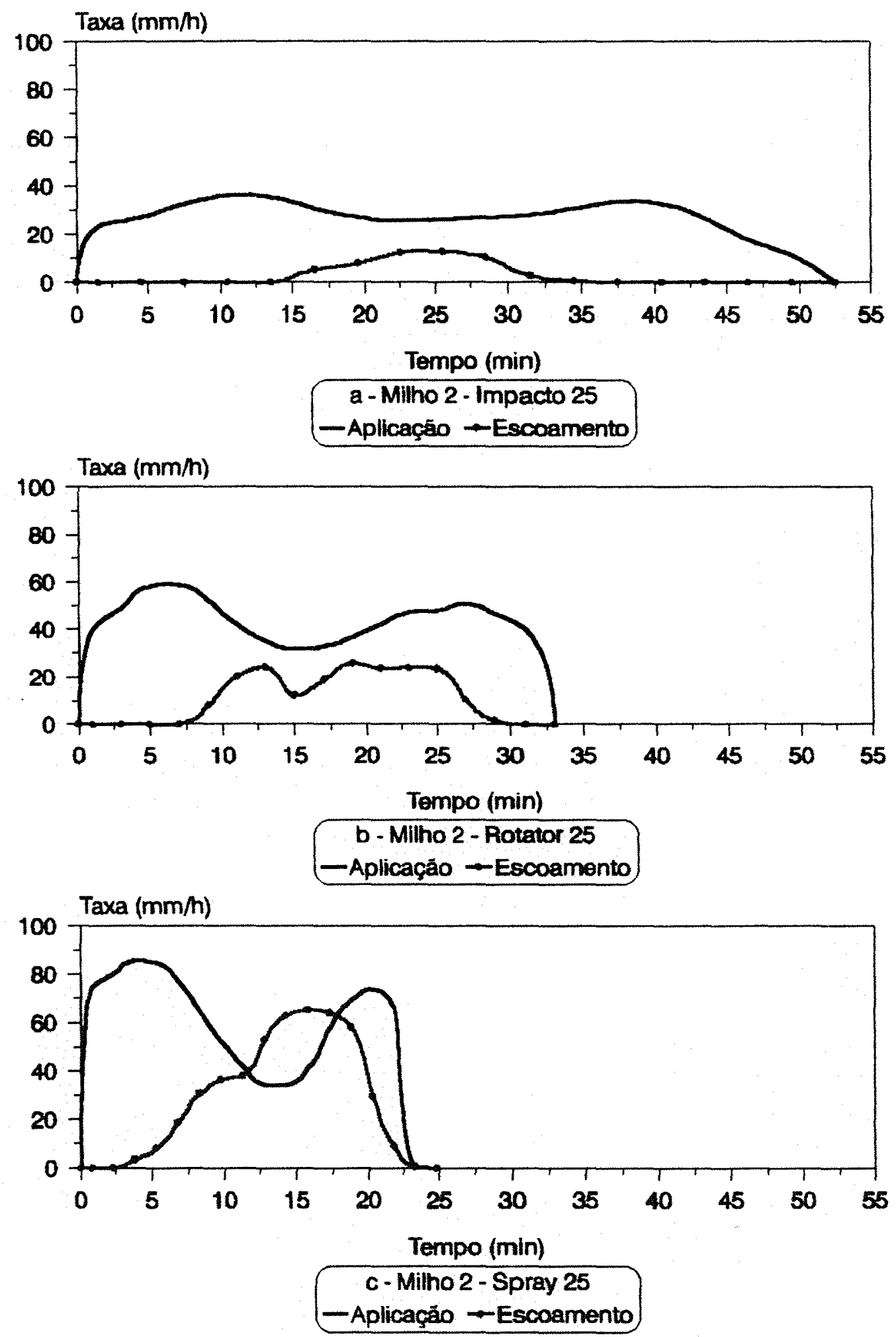

Figura 13 - Curvas de taxa de aplicação e escoamento para milho 2 e lâmina 25 mm 

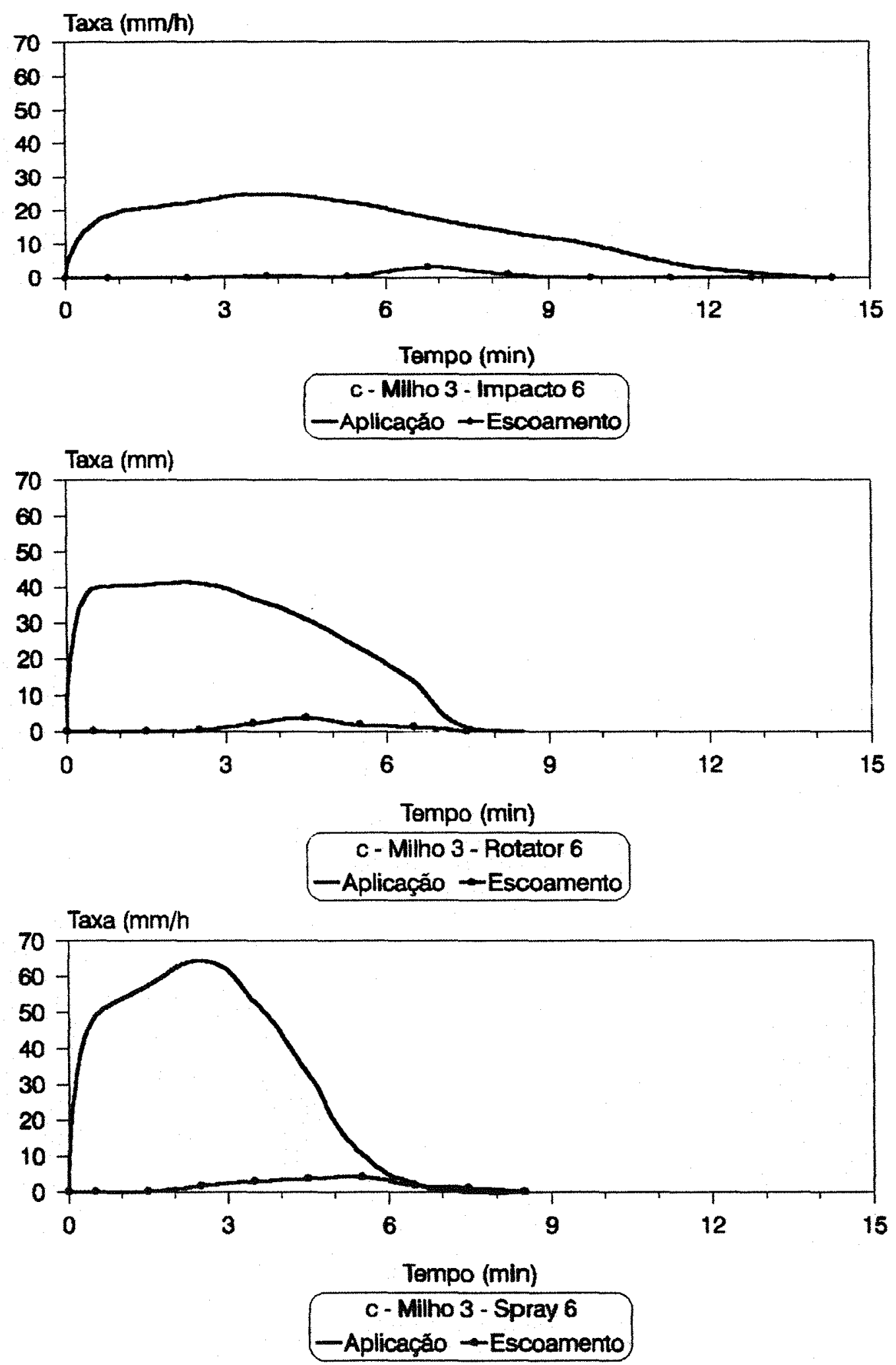

Figura 14 - Curvas de taxa de aplicação e escoamento para milho 3 e lâmina $6 \mathrm{~mm}$ 


\section{3 - Lâminas de aplicação, escoamento e retenção foliar}

A Tabela 9 mostra os resultados de lâmina coletada, escoada e retida nas folhas, perdas por escoamento e retenção foliar, em mm e percentagem, e taxa de aplicação máxima, em função do tipo de emissor, estádio do milho e lâmina de irrigação aplicada. A percentagem de lâmina escoada foi calculada em relação à lâmina coletada no ensaio. A percentagem de retenção foliar foi calculada pela relação entre lâmina retida e lâmina coletada sem a presença do dossel vegetativo (milho no estádio 1). A perda em $\mathrm{mm}$ foi calculada pela soma das lâminas retida e escoada, e em percentagem, pela relação entre perdas em mm e lâmina coletada sem presença do dossel vegetativo (milho 1).

Tabela 9 -Dados de lâminas de aplicação, escoamento e retenção foliar obtidos nos ensaios.

\begin{tabular}{|l|c|c|c|c|c|c|c|c|}
\hline \multicolumn{1}{|c|}{ Ensalo } & $\begin{array}{c}\text { Lâmina } \\
\text { Coletada }\end{array}$ & $\begin{array}{c}\text { Lâmina } \\
\text { Escoada }\end{array}$ & $\begin{array}{c}\text { Lâmina } \\
\text { Escoada }\end{array}$ & $\begin{array}{c}\text { Taxa de } \\
\text { Aplicaça } \\
\text { Márma } \\
\mathbf{m m}\end{array}$ & $\begin{array}{c}\text { Retençăo } \\
\text { Follar }\end{array}$ & $\begin{array}{c}\text { Retençao } \\
\text { Follar }\end{array}$ & Perda & Perda \\
\hline M1-Impacto6 & 5,7 & 0,3 & 6 & 44 & - & - & 0,3 & 6 \\
\hline M1-Rotator6 & 5,8 & 0,2 & 4 & 62 & - & - & 0,2 & 4 \\
\hline M1-Spray6 & 5,6 & 0,3 & 6 & 65 & - & - & 0,3 & 6 \\
\hline M1-Impacto25 & 24,9 & 2,6 & 11 & 44 & - & - & 2,6 & 11 \\
\hline M1-Rotator25 & 25,2 & 6,5 & 26 & 65 & - & - & 6,5 & 26 \\
\hline M1-Spray25 & 26,0 & 8,8 & 34 & 88 & - & - & 8,8 & 34 \\
\hline M2-Impacto6 & 3,1 & 0,1 & 3 & 25 & 2,6 & 46 & 2,7 & 47 \\
\hline M2-Rotator6 & 3,8 & 0,6 & 15 & 56 & 2,0 & 34 & 2,6 & 44 \\
\hline M2-Spray6 & 4,4 & 0,7 & 16 & 55 & 1,2 & 21 & 1,9 & 34 \\
\hline M2-Impacto25 & 23,2 & 2,6 & 11 & 36 & 1,7 & 4 & 4,3 & 17 \\
\hline M2-Rotator25 & 23,4 & 6,4 & 27 & 61 & 1,8 & 7 & 8,2 & 33 \\
\hline M2-Spray25 & 24,9 & 11,9 & 48 & 86 & 1,1 & 4 & 13,0 & 50 \\
\hline M3-Impacto6 & 3,4 & 0,1 & 4 & 25 & 2,3 & 40 & 2,4 & 42 \\
\hline M3-Rotator6 & 3,9 & 0,2 & 4 & 41 & 1,9 & 33 & 2,1 & 35 \\
\hline M3-Spray6 & 4,4 & 0,3 & 4 & 64 & 1,2 & 21 & 1,5 & 26 \\
\hline
\end{tabular}

A Figura 15 mostra os valores de taxa de aplicação média e máxima determinadas nos ensaios, em relação aos valores teóricos. Os valores encontrados para o aspersor de impacto foram os que mais se aproximaram dos teóricos, enquanto que para 0 
"spray", os valores foram os mais distantes. Isto provavelmente se deve a relação entre o tempo de aplicação e o intervalo de tempo adotado, que parece ter sido mais adequada para o aspersor de impacto. O "spray", por apresentar um tempo de aplicação curto, exigiria um intervalo de tempo bem pequeno, o que é inviável pela metodologia utilizada. A presença do dossel vegetativo reduziu a taxa de aplicação máxima, sendo que este efeito foi mais pronunciado quando se utilizou a lâmina de $6 \mathrm{~mm}$, principalmente no aspersor de impacto. Os valores encontrados seriam mais próximos dos teóricos, se fosse considerada a eficiência de aplicação potencial.
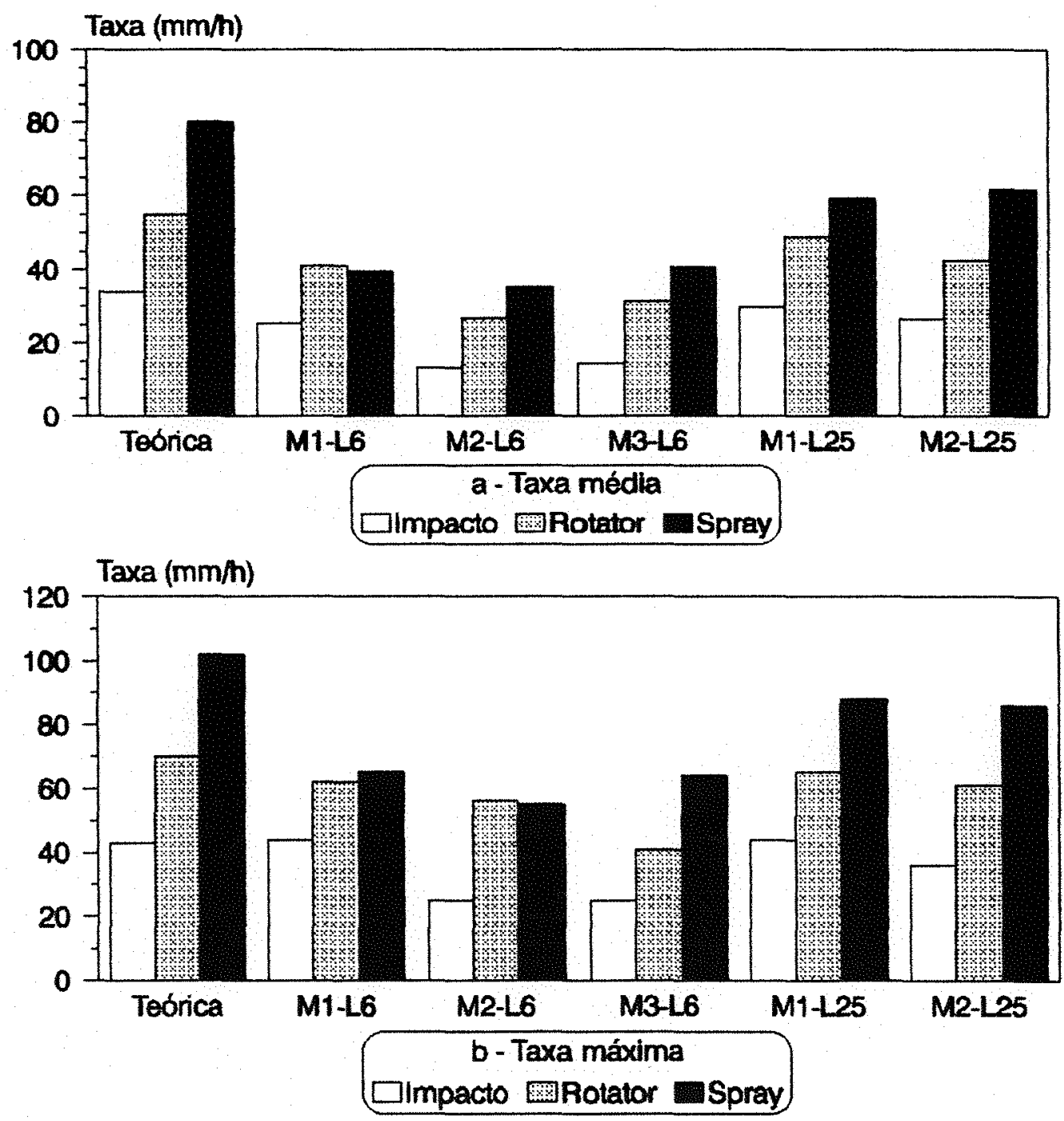

Figura 15 - Taxas de aplicação média e máxima determinadas nos ensaios. 
Na Figura 16 são apresentados os valores de escoamento em lâmina e percentagem em relação à lâmina coletada. Observa-se que o escoamento para o "spray" foi sempre maior e para o aspersor de impacto, sempre menor. Destaca-se o alto valor de escoamento para o "spray" aplicando lâmina de $25 \mathrm{~mm}$, com o milho no estádio 2 . Valores ainda superiores foram encontrados por ADDINK (1975), que determinou um escoamento de $65 \%$ no final de um pivô de $400 \mathrm{~m}$ de raio equipado com "sprays". GILLEY et al. (1986) encontraram escoamento de 1,1, 1,6 e 8,1 \% para aspersor de impacto de alta e baixa pressão e "sprays" (média de 4 anos), num solo com 3,5\% de declividade e lâmina de aplicação de $37,6 \mathrm{~mm}$. GILLEY \& MIELKE (1980) encontraram 25 e $28 \%$ de escoamento para aspersor de impacto e "spray", num solo com $3,5 \%$ de declividade e com uma cultura de mitho já desenvolvida. DEBOER et al. (1992) encontraram escoamento de 20 e $10 \%$ para "spray" e aspersor de impacto de média pressão. ALENCAR (1988) encontrou escoamento de 30,1 e $18,7 \%$ para "spray" e aspersor de impacto. Entretanto, comparar estes valores é pouco válido, porque existe influência da lâmina aplicada, declividade, textura e teor de umidade do solo. A percentagem de escoamento aumentou com a lâmina aplicada, aumentando no meio do ciclo (milho no estádio 2), mesmo com a presença do dossel vegetativo. Isto pode ser explicado pelo selamento superficial e uniformização da superfície do solo, reduzindo a capacidade de infiltração e de armazenamento superficial.

A Figura 17 mostra os valores de retenção foliar pelo dossel vegetativo em mm e percentagem em relação à lâmina coletada sem presença do dossel (milho no estádio 1). Os valores de lâmina retida estão de acordo com STENER et al. (1986), que encontrou valores médios de 2,7 , variando de 0,8 a $7,0 \mathrm{~mm}$, para um IAF superior a 3, A retenção foi maior para o aspersor de impacto e menor para o "spray", fato também observado por KELSO \& GLLEY (1983), que encontraram 8,1 e 1,7 mm, respectivamente. $\mathrm{O}$ aspersor de impacto possui um espectro de diâmetro de gotas variando 
de pequenas a grandes, favorecendo a retenção. $O$ "spray", por possuir uma alta taxa de aplicação e gotas caindo mais verticalmente na altura do topo da cultura consegue maior penetração no dossel, e assim menor retenção. A retenção é relativamente constante em função da lâmina aplicada, porém passa a ser significativa quando se utiliza lâminas pequenas, como também observaram STEINER et al (1986) e AYARS et al (1991). Este aspecto é importante quando se realiza práticas de quimigação e o alvo é a planta (fungicidas, inseticidas, herbicidas de pós emergência). Como a lâmina retida é aproximadamente constante, neste caso deve-se utilizar a menor lâmina possível para
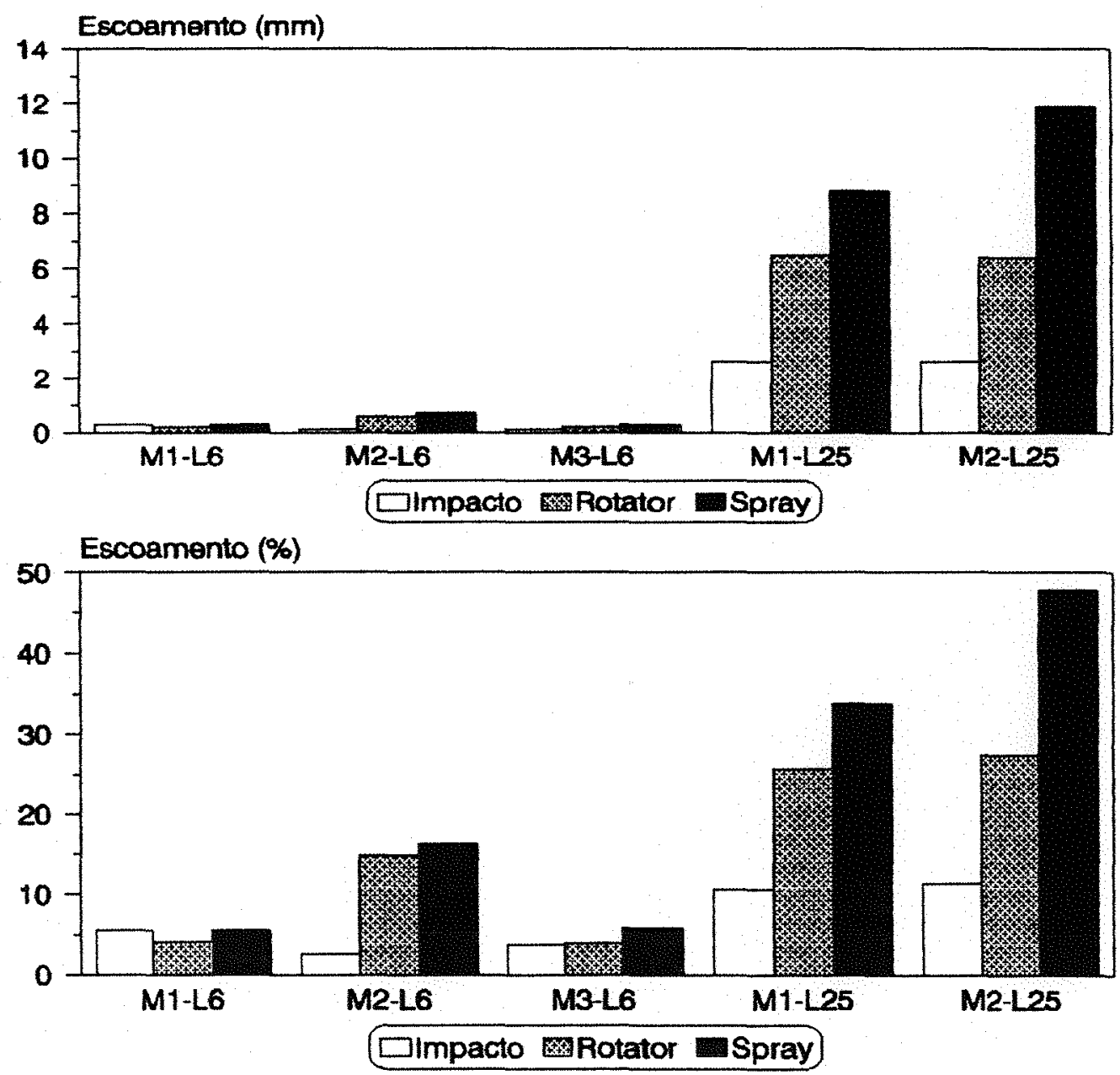

Figura 16 - Valores de escoamento determinados nos ensalos 

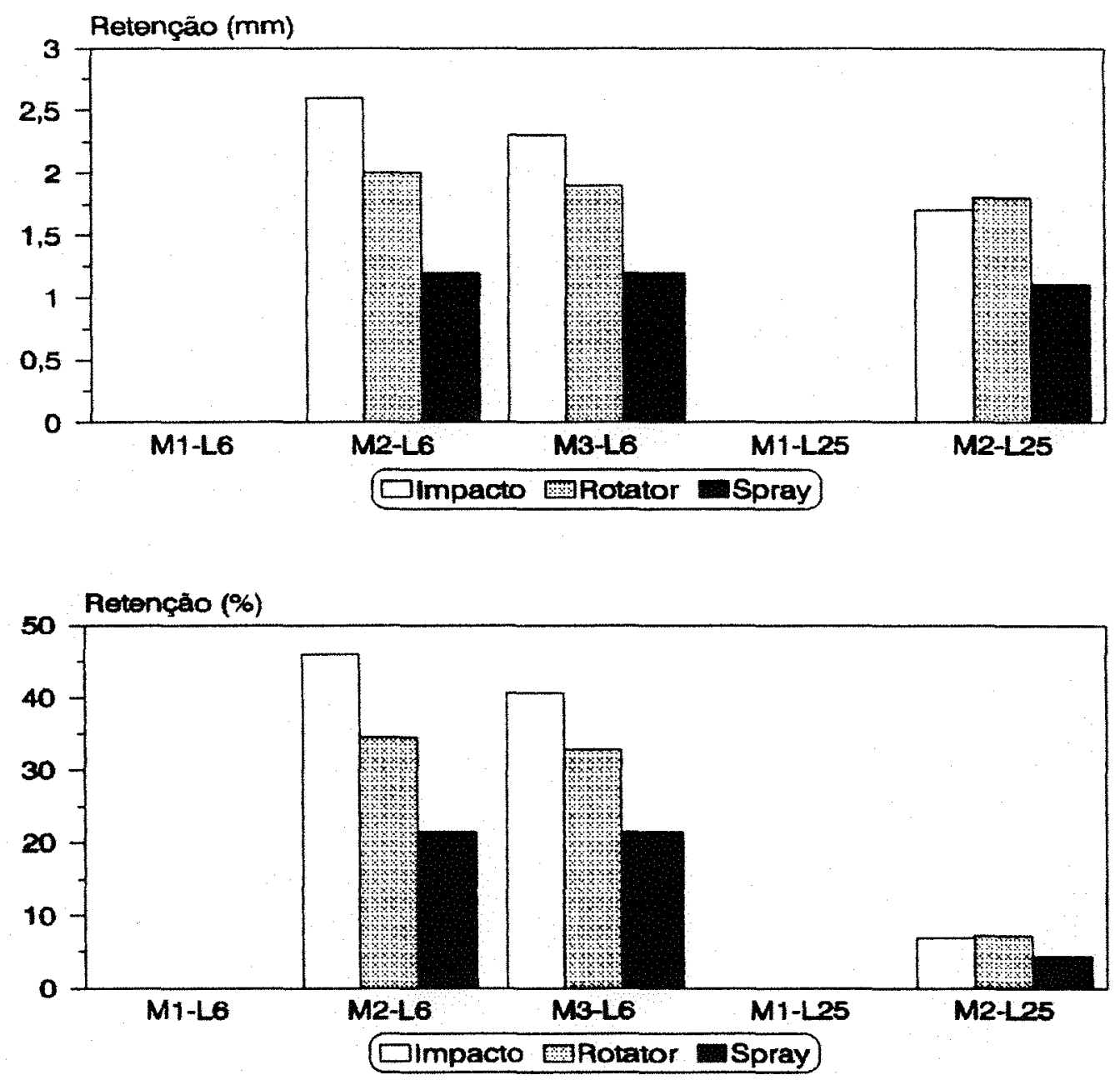

Figura 17 - Valores de retenção foliar determinados nos ensaios

maximizar a retenção foliar. Quando o alvo for o solo (fertilizantes, herbicidas de pré emergência), deve-se utilizar lâminas maiores, desde que o escoamento não seja significativo, para minimizar a retenção foliar.

As lâminas de retenção foliar encontrados devem ser considerados como lâmina bruta, pois esta água retida não pode ser considerada como totalmente perdida. Segundo STENER et al. (1986), a água retida contribui para reduzir a transpiração das plantas enquanto se evapora. Parte desta água que se estimou retida nas folhas pode ter escomido pelo tronco das plantas e atingido o solo. STEINER et al. (1986) estimou que $45 \%$ da água que atinge o topo da cultura chega ao solo escorrendo pelo caule. 
Entretanto, esta água escorrida contribuiu para molhar o espaço próximo a linha da cultura, onde a grande presença de folhas torna dificil a água atingir o solo diretamente.

A soma das perdas por escoamento e retenção foliar são mostradas na Figura 18, em mm e percentagem em relação à lâmina coletada sem a presença de dossel vegetativo (milho no estádio 1). Observa-se que quando se utiliza lâmina menor, a influência da retenção foliar é maior e as perdas maiores ocorrem no aspersor de impacto. No milho no estádio 1 e lâmina de $6 \mathrm{~mm}$, as perdas são pequenas porquê não há dossel vegetativo e o escoamento é pequeno. Quando se utiliza lâminas maiores, passa a existir escoamento significativo e as perdas são maiores para o "spray". As perdas tendem a aumentar ao longo do ciclo, como observado por PRUSKI et al (1993), porque ocorre redução na capacidade de infiltração de água no solo e passa a existir o fenômeno da retenção foliar.

Portanto, como sugestão de manejo, deve-se utilizar lâminas pequenas quando a cultura do milho estiver no estádio inicial. Após o estabelecimento do dossel vegetativo, utilizar lâminas intermediárias, de modo que ocorra pouco escoamento e a retenção foliar, embora presente, seja pouco significativa.

Observa-se que, ao analisar o desempenho de um sistema de irrigação, é necessário considerar a sua interação com o solo e a cultura. Este estudo deve ser feito ao longo do ciclo da cultura irrigada, porque o meio agrícola é dinâmico, com as características do solo e da planta mudando no decorrer do ciclo.

Observou-se que a água proveniente do escoamento nos ensaios com o milho no estádio 1 era de cor escura, contendo muitas partículas de solo em suspensão, ao passo que nos estádios posteriores, era bem mais clara. Isto indica que as perdas de solo devido ao escoamento ocorrem principalmente no ínício do ciclo da cultura. Isto se deve pelo fato do solo estar movimentado pelo seu preparo e porque as gotas de água atingem a sua superficie diretamente. Posteriormente, ocorre uma ligeira compactação que reduz o 
arrastamento de solo pelo escoamento e o dossel vegetativo passa a oferecer uma proteção contra o impacto das gotas d'água, através da redução da sua energia cinética.
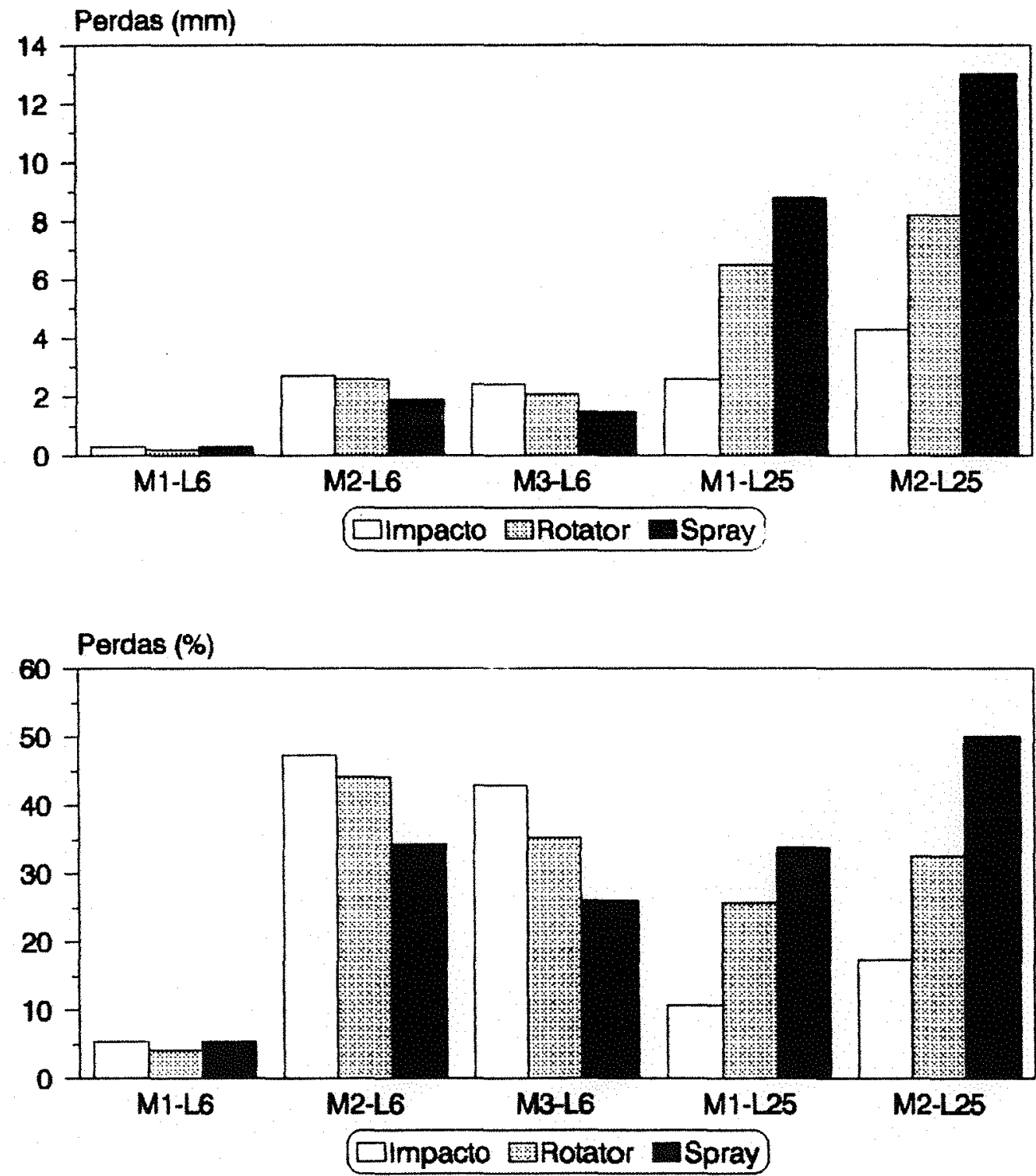

Figura 18 - Perdas somadas de escoamento e retenção foliar determinadas nos ensaios 


\section{4-4 - Determinação da curva de infiltração de água no solo}

As curvas de aplicação e escoamento acumulados, originais (F0) e após a aplicação da média móvel por 3 vezes (F3), relativas aos testes de infiltração, estão na Figura 19.

As curvas de taxa de aplicação, escoamento e infiltração obtidas a partir dos dados acumulados estão na Figura 20. Como no início a taxa de infiltração é controlada pela taxa de aplicação, como afirmam SKAGGS et al (1983), a curva de infiltração não pode ser determinada pela metodologia utilizada e foi representada por uma linha reta horizontal.

Como o tempo de aplicação de água pelo pivô é relativamente curto, o solo não atingiu a velocidade de infiltração básica do solo (VIB), que entretanto, pela tendência da curva de infiltração, situa-se na faixa dos $10-12 \mathrm{~mm} / \mathrm{h}$.

Observa-se também a importância de se considerar o teor de umidade do solo no momento de se fazer o teste de infiltração. No solo mais úmido ( $23 \% \mathrm{em}$ peso), a infiltração começou a se estabilizar após 20 minutos, aproximadamente, enquanto que com o solo mais seco (18\% em peso), após 60 minutos, aproximadamente. 

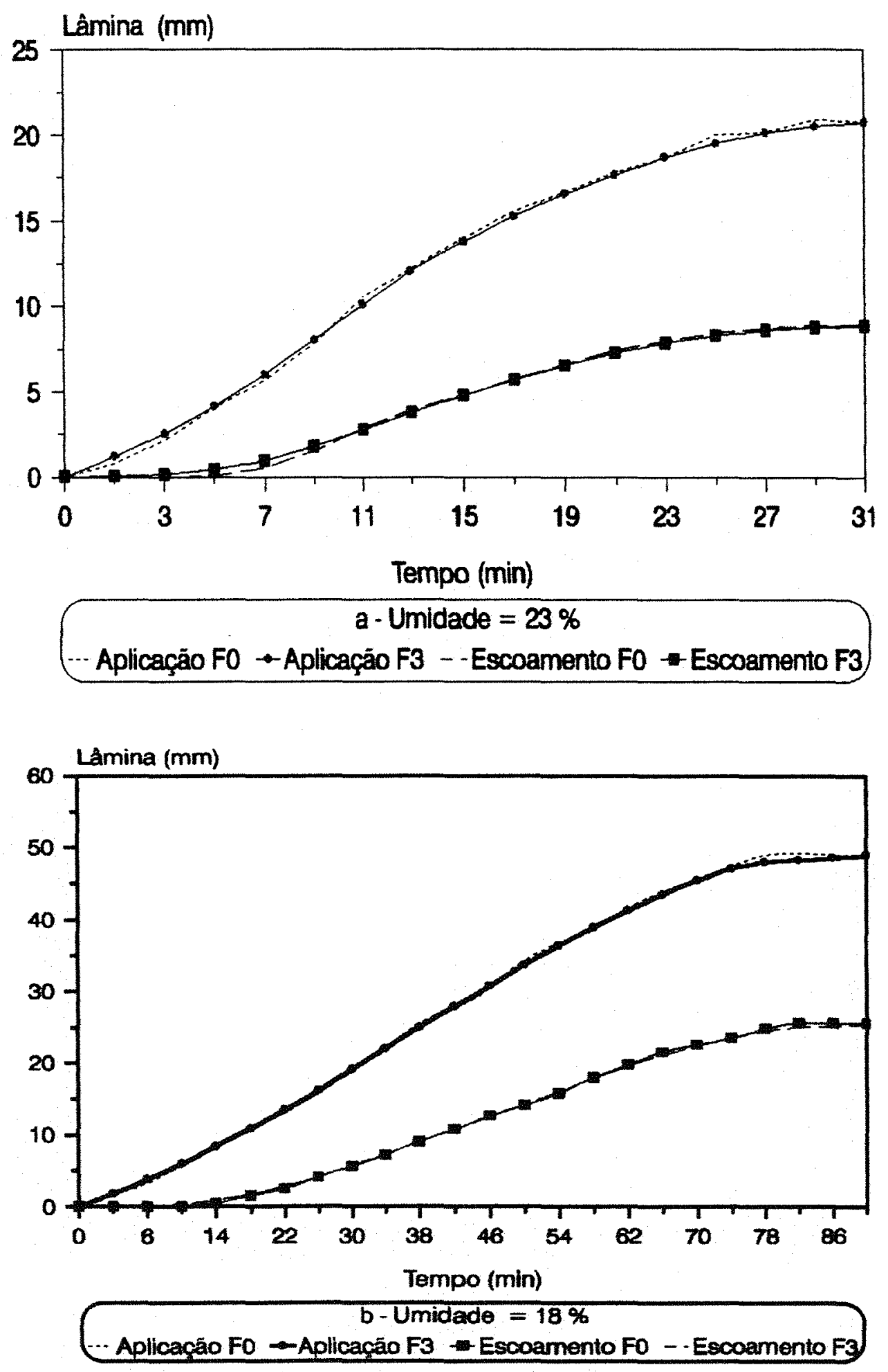

Figura 19 - Curvas de aplicação escoamento acumulados dos testes de infiltração, antes e após a aplicação da média móvel. 

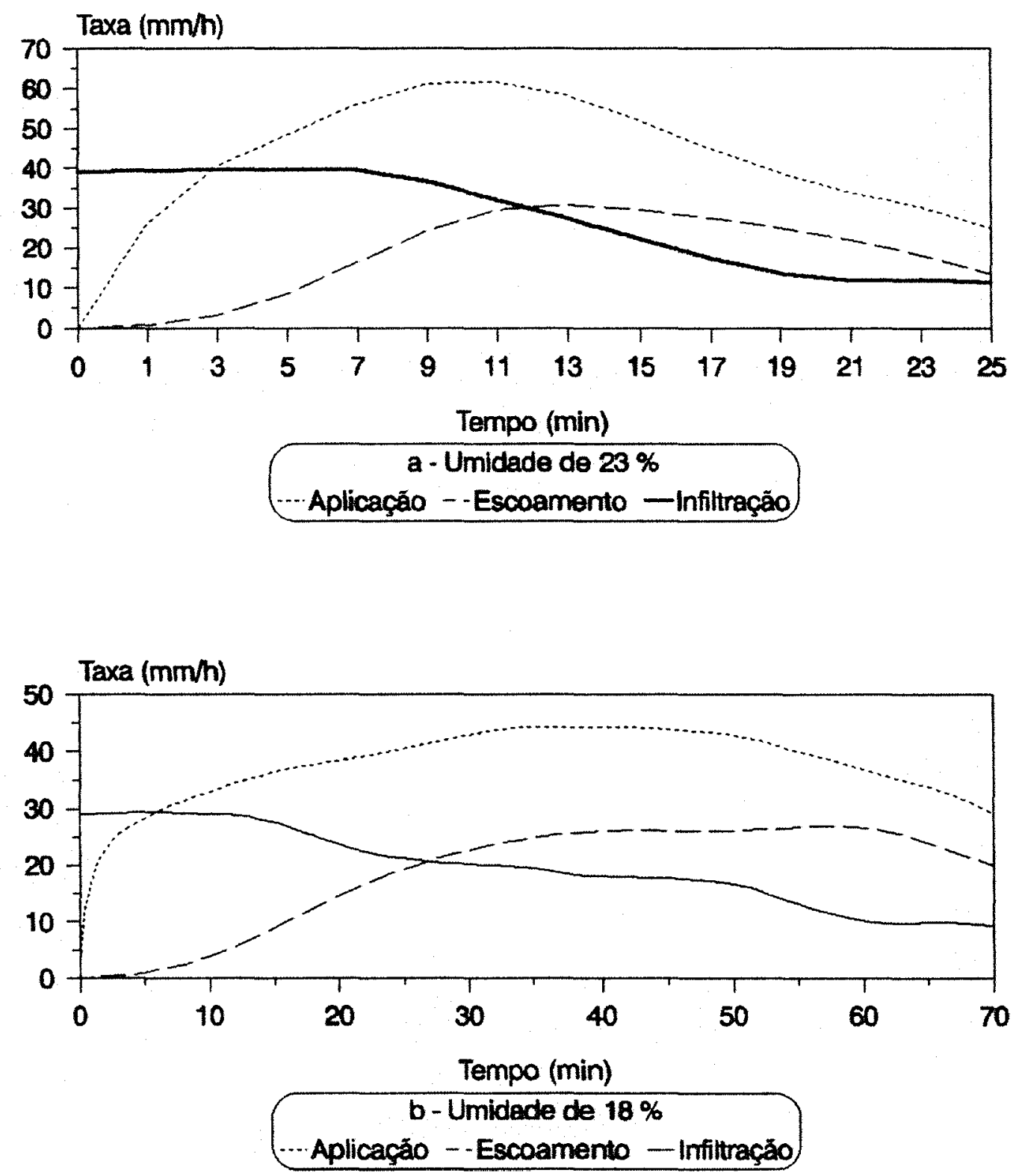

Figura 20 - Curvas de taxa de aplicação, escoamento e infiltração obtidas em função da umidade do solo.

\section{5 - Consumo de energia}

Para analizar o efeito da utilização dos emissores em estudo na economia de energia, foi feita uma simulação da pressão no ponto do pivô e altura manométrica total 
do sistema, na situação mais comum para as condições brasileiras, em que a fonte de água está localizada fora da área irrigada, sendo necessária uma adutora para conduzir água até o ponto do pivô. Para o pivô simulado, assumiu-se que:

- a fonte de água está a $550 \mathrm{~m}$ do ponto do pivô; a adutora é de ferro fundido (C coeficiente de atrito de Hazen-Williams igual a 135), diâmetro de 8" (203,2 mm)

- o desnivel geométrico mais perda de carga na sucção é de 5 mca (49 KPa)

- a lateral do pivô possui diâmetro de $65 / 8^{n}$ (168,3 mm), C =125

- o fator $\mathrm{f}$ de redução de perda de carga para múltiplas saídas, para o pivô central é 0,555 (KELLER \& BLIESNER, 1990)

- a altura do pivô ao solo é $3,5 \mathrm{~m}$

- o pendural utilizado é de PVC (C=130), diâmetro 3/4" (19 mm), $1 \mathrm{~m}$ de comprimento, vazão do último emissor igual a $2,37 \mathrm{~m}^{3} / \mathrm{h}$

- é necessária uma pressão adicional $5 \mathrm{mca}(49 \mathrm{KPa})$ no últímo emissor, para compensar a perda de carga no regulador de pressão

A pressão necessária no ponto do pivô pode ser calculada por:

$$
P_{p}=H+h_{f} L+P_{s}+h_{f} R P+h_{f} P+\Delta_{z}
$$

em que :

$P_{p}$ - pressão necessária no ponto do pivô (mca)

H - altura do pivô ao solo (m)

$h_{f} L$ - perda de carga na tubulação da lateral (mca)

Ps - pressão de serviço do emissor utilizado (mca)

$h_{f} R P$ - perda de carga no regulador de pressão (mca)

$h_{\mathbf{f}} \mathbf{P}$ - perda de carga no pendural (m)

$\Delta_{Z}$ - desnivel geométrico entre o ponto do pivô e a maior cota da área irrigada

A altura manométrica total pode ser calculada por

$$
H m=P_{p}+\Delta_{z} P+h f A+h f S+\Delta_{z^{s}}
$$


em que :

$\mathrm{H} m$ - altura manométrica total do sistema (mca)

$\Delta_{\mathrm{Z}} \mathrm{P}$ - desnivel geométrico entre a cota da motobomba e a cota do ponto do pivô (m)

$h_{f} A$ - perda de carga na adutora (mca)

$\mathbf{h}_{\mathbf{f}} \mathbf{S}$ - perda de carga na sucção (mca)

$\Delta_{Z^{s}}$ - desnível geométrico entre a motobomba e a fonte de água

Nestas condições, utilizando-se a equação de Hazen-Williams, a perda de carga na adutora é de $12,0 \mathrm{mca}(118 \mathrm{KPa})$, no pendural é de $0,6 \mathrm{mca}(6 \mathrm{KPa})$ e na lateral do pivô de 17,5 mca (172 $\mathrm{KPa})$, assumindo essa ser igual para os três emissores.

Simulando situações de declividade uniforme numa faixa comum em áreas irrigadas (0 a $10 \%$ ), a Figura 21 mostra a necessidade percentual de pressão dos "sprays" fixo e rotativo em relação ao aspersor de impacto, no ponto do pivô e altura manométrica total.

O efeito do tipo de emissor é mais acentuado no ponto do pivô em relação à altura manométrica total. $O$ efeito será menos acentuado a medida que se aumenta a perda de carga na lateral ( por redução do diâmetro, aumento do comprimento ou da vazão), ou como mostrado na figura 21 , pelo aumento do desnível entre o ponto do pivô e o ponto mais alto da área irrigada.

Na altura manométrica total, o efeito do tipo de emissor é menos pronunciado, porque passam a existir componentes que independem do emissor utilizado. Este efeito será menos pronunciado a medida que diminui a relação $\mathrm{P}_{\mathrm{p}} / \mathrm{Hm}$, que pode ser por aumento do desnivel geométrico entre a motobomba e o pivô (como mostrado na figura 21), ou da perda de carga na adutora (por redução do diâmetro ou aumento do comprimento ou da vazäo).

Em ambos os casos, a pequena diferença entre o "spray" fixo e o rotativo se deve a instalação do "spray" fixo em pendural, onde apesar de haver perda de carga, a redução da altura ao solo permite um ganho de energia. 


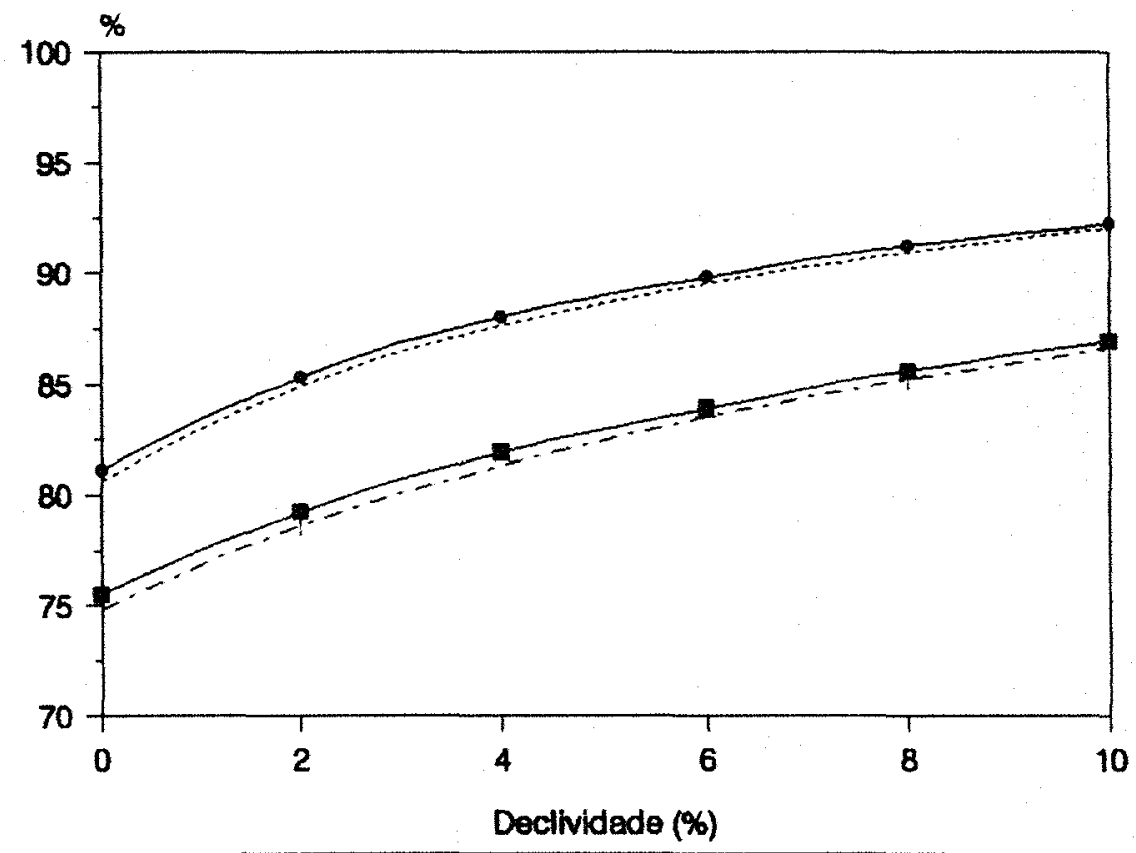

- Rotator - Pressáo no Pivó - Rotator - Hm Total
- Spray - Pressáo no Plvó $\cdots$ Spray - Hm Total

Figura 21 - Necessidade de pressão relativa utilizando os emissores de baixa pressão e variando a declividade do terreno

O efeito no consumo de energia é diretamente proporcional à altura manométrica total, podendo ser calculada por:

$$
N=\gamma \frac{Q H_{m}}{75 \eta}
$$

em que :

$\mathrm{N}$ - potência absorvida na bomba (cv)

$y$ - peso específico da água $\left(\mathrm{kg} / \mathrm{m}^{3}\right)$

$\mathrm{Q}$ - vazão necessária $\left(\mathrm{m}^{3} / \mathrm{s}\right)$

$\mathrm{H}_{\mathrm{m}}$ - altura manométrica $(\mathrm{m})$

$\eta$ - rendimento da bomba

Utilizando motor elétrico e assumindo para os valores de altura manométrica e vazão considerados, $\eta$ da bomba igual a 0,80 (AZEVEDO NETTO \& 
ALVAREZ, 1991), a potência absorvida varia de 88 a 212 CV para o aspersor de impacto e de 71 a 195 CV para os "sprays" fixo e giratório, variando a declividade de 0 a $10 \%$. Como a potência absorvida é diretamente proporcional à altura manométrica, sua curva percentual é a mesma da altura manométrica total. Portanto, a motobomba de um pivô central equipado com "sprays" de baixa pressão consome, nas condições simuladas, 81 a $92 \%$ da energia utilizada pelo mesmo pivô central , se for equipado com o aspersor de impacto de média pressão.

Observa-se portanto que a economia de energia pela utilização de emissores de baixa pressão é mais significativa quanto maior a relação $\mathrm{P}_{\mathrm{p}} / \mathrm{Hm}$. Nas condições brasileiras, a concepção original do projeto do pivô central para captar água subterrânea diretamente no ponto do pivô foi modificada pela necessidade de captação de água fora da área irrigada, exigindo a utilização de uma adutora para conduzir água até o ponto do pivô. Portanto, a vantagem em termos de consumo de energia pela utilização de emissores de baixa pressão fica reduzida nestas condições, pois existe influência do emissor apenas na pressäo no ponto do pivô, sendo que na altura manométrica total passam a existir componentes que independem do tipo de emissor utilizado. Outro fator que contribui para reduzir a economia energética, mesmo no ponto do pivô, consiste no fato de que no Brasil, a área irrigada por equipamento é grande, exigindo laterais de grande comprimento, aumentando desse modo a importância da componente perda de carga na lateral. Portanto, economias de energia de 20 a $40 \%$ (GILLEY et al., 1983) e até 40 \% (JAMES \& BLAIR, 1984), dificilmente serão conseguidas nas nossas condições. 


\section{5 - CONCLUSÕES E RECOMENDAÇÕES}

Os resultados obtidos nas condições em que foi realizado o trabalho permitem as seguintes conclusões e recomendações :

- o "spray" fixo provocou os maiores valores de escoamento superficial e taxa de aplicação e o aspersor de impacto os maiores valores de retenção foliar, com o "spray" rotativo apresentando comportamento intermediário.

- o aumento da lâmina de irrigação aumenta as perdas por escoamento superficial, enquanto que sua redução aumenta importância relativa da retenção foliar; essas perdas podem comprometer a eficiência de irrigação do sistema.

- o manejo da irrigação na cultura do milho deve ser feito aplicando-se lâminas pequenas durante o estádio de estabelecimento; após o desenvolvimento vegetativo, deve-se utilizar lâminas intermediárias entre aquelas utilizadas, para reduzir o escoamento superficial e minimizar a importância da retenção foliar.

- os emissores de baixa pressão proporcionaram uniformidade de aplicação de água comparável ao de média pressão, chegando a ser superior no caso do "spray" rotativo.

- a utilização de emissores de baixa pressão permite a redução da pressão de operação do pivô e a economia de energia em relação aos emissores de média pressão será proporcional à relação pressão no ponto do pivô / altura manométrica total, variando com as condições topográficas, tamanho, diâmetro e vazão da lateral. 
- a metodologia utilizada para determinação das taxas de aplicação e escoamento, dentro da sua filosofia de utilizar equipamentos simples, mostrou-se satisfatória, devendo-se desenvolver procedimentos que permitam a obtenção de dados em intervalos de tempo menores, para melhorar a precisão.

- a metodologia permite estimar satisfatoriamente a curva de infiltração de solos sob irrigação a taxa variável, como no sistema pivô central; a escolha do emissor para o teste de infiltração deve levar em conta o tempo de aplicação, para que seja aproximado o valor da VIB, além de se considerar a umidade inicial do solo.

- é aconselhável realizar o trabalho em outras condições de cultura, solo, sistema de cultivo, configuração de emissores e tamanho do equipamento, para permitir conchusões mais seguras e abrangentes. 


\section{REFERÊNCIAS BIBLIOGRÁFICAS}

AARSTAD, J.S \& MILLE, D. Soil management to reduce runoff under center-pivot sprinkler systems. Journal of Soil and Water Conservation, Ankeny , 28: 171-3, Jul./Aug. 1973.

ABO-GHOBAR, H.M. Losses from low-pressure center pivot irrigation systems in a desert climate as affected by nozzle height. Agricultural Water Management , Phoenix, 21 : 23-32, Jun. 1992.

ADDINK, J.W. Runoff potential of spray-nozzle and sprinkler center-pivot. St. Joseph, ASAE, 1975. 19 p. (ASAE Paper 75-2086)

ADDINK, J.W.; MILES, D.L.; SKOGERBOE, G.V. Water intake under center pivot from time variyng application rates. Transactions of ASAE, St. Joseph, 18 (3): 523-8, May./Jun. 1975.

ADDINK,J.W.; KELLER,J.; SNEED,R.E.; WOLF,J.W. Design and operation of sprinkler systems. In: JESEN, M.E., ed. Design and operation of farm irrigation systems. St. Joseph, ASAE, 1983. p. 621-58 (ASAE Monograph, 3) 
ALENCAR, C. A. B. Intensidade de aplicação e escoamento superficial em irrigação com pivôs centrais de baixa e média pressão. Viçosa, 1988. 87p. (M.S.Universidade Federal de Viçosa)

AMERICAN SOCIETY OF AGRICULTURAL ENGINEERS. Test Procedure for determining the uniformity of water distribuition of center pivot, corner pivot, and moving lateral irrigation machines equipped with spray or sprinkler nozzles. St. Joseph, 1991. p.643-53. (ASAE Standard, S436)

AYARS, J.E.; HUTMACHER, R.B.; SCHONEMAN, R.A.; DETTINGER, D.R. Influence of cotton canopy on sprinkler irrigation uniformity. Transactions of ASAE, St. Joseph, 34(3): 890-6. May./Jun. 1991.

AZEVEDO NETTO, J.M.\& ALVAREZ, G.A. Manual de hidráulica. São Paulo, Edigar Blucher, 1991. v. 1, 335p.

BRIDI, S. Análise da uniformidade de distribuição de água em sistema de irrigação pivô central. Viçosa, 1984. 87p. (M.S. - Universidade Federal de Viçosa)

COTRMM, C. E. Análise da uniformidade de aplicação de água, em sistema de irrigação do tipo pivô central de baixa pressão. Viçosa, 1988. 114 p. (M.S. - Universidade Federal de Viçosa)

DEBOER, D.W.; BECK, D.L.; BENDER. A.R. A field evaluation of low, medium and high pressure sprinklers. Transactions of ASAE, St. Joseph, 35(4): 1185-9, Jul./Aug. 1992. 
DILLON, R.C; HIIER, E.A; VITTETOE, G. Center-pivot sprinkler design based on intake characteristics. Transactions of ASAE, St. Joseph, 15(5): 996-1001, Sep./Oct. 1972.

EVANS, R.G. Low pressure center-pivot sprinkler systems. Fort Collins, Colorado State University Extension Service, 1980. 3p. (Bulletin Service in Action, 4.711)

GILLEY, J.R. Suitability of reduced pressure center-pivots. Journal of Irrigation and Drainage Engineering, New York, 110(1): 22-34, May. 1984.

GILLE, J.R \& MIELKE, L.N. Conserving energy with low-pressure center pivots. Journal of Irrigation and Drainage Division, New York, 106(1R1): 49-59, Mar. 1980.

GILLEY, J.R \& SUPALLA, R.J. Economic analysis of energy savings in irrigation. Transactions of ASAE, St. Joseph, 26(6): 1784-92, Nov./Dec. 1983.

GILLEY, J.R \& WATTS, D.G. Possible energy savings in irrigation. Journal of Irrigation and Drainage Division, New York, 103(1R4): 445-57, Dec. 1977.

GILLEY, J.R; MIELKE, L.N; WILHELM, W.W. An experimental center-pivot irrigation system for reduced energy crop production studies. Transactions of ASAE . St. Joseph, 26(5): 1375-85, Sep./Oct. 1983. 
GILLEY, J.R.; SUPALLA, D.R.; LARUE, J.L. Low pressure sprinkler packages for moving irrigation systems. St. Joseph, ASAE, 1986. 19 p. (ASAE Paper, 862088)

GILLEY, J.R; HACKBART, C.A; STETSON, L.E; FEYEN, J. Energy management. In: HOFFMAN, G.J; HOWEL, T.A; SOLOMON, K.N., ed. Management of farm irrigation systems, St. Joseph, ASAE, 1990. p. 719-46.

HANSON, B.R. \& WALLENDER, W.W. Bidirecional uniformity of water applied by continuous-move sprinkler machine. Transactions of ASAE, St. Joseph, 29(4): 1047-53, Jul./Aug. 1986.

HEERMANN, D.F \& HEIN, P.R. Performance characteristics of self-propelled centerpivot irrigation system. Transactions of ASAE, St. Joseph, 11(1): 11-5, Nov./Dec. 1968.

HEERMANN, D.F.\& KOHL, R.A. Fluid dinamics of sprinkler systems. In : JESEN, M.E., ed. Design and operation of farm irrigation systems. St. Joseph, ASAE, 1983. p. 583 - 614 (ASAE Monograph, 3)

HEERMANN, D.F; WALENDER, W.W; BOS, M.G. Irrigation efficiency and uniformity. In: HOFFMAN, G.J; HOWEL, T.A; SOLOMON, K.N., ed. Management of farm irrigation systems. St. Joseph, ASAE, 1990. p.125-49. 
INSTITUTO DE PESQUISAS TECNOLÓGICAS. Apoio técnico ao programa de crédito rural para lavouras irrigadas nas regiões de Guaíra e São João da Boa Vista - SP. São Paulo, 1993. 9 p. (IPT Relatório, 31.397-3)

JAMES, L.G \& BLAIR, S.K. Performance of low pressure center pivot systems. Transactions of ASAE, St. Joseph, 27(6): 1753-62. Nov./Dec. 1984.

JONHSON, G.C; ROCHESTER, E.W; HATCH, L.U; CURTIS, L.M; YOO, K.H. Analisys of center pivot irrigation systems operating in a humid-area environment. Transactions of ASAE, St. Joseph, 30(6): 1720-25, Nov./Dec. 1987.

KELLER, J. \& BLIESNER, R.D. Sprinkle and trickle irrigation. New York, Avibook, 1990. 652p.

KELSO, G.L \& GILLEY, J.R. A system for measuring infiltration rates under center pivot irrigation systems. Chicago, ASAE, 1983. 25 p. (ASAE Paper, 83-2517).

KINCAID, D.C; HEERMANN, D.F; KRUSE, E.G. Application rates and runoff in center-pivot sprinkler irrigation. Transactions of ASAE, St. Joseph, 12(6): 790-7, Nov./Dec. 1969.

KOLUVEK, P.K; TANJI, K.K; TROUT, T.J. Overview of soil erosion from irrigation. Journal of Irrigation and Drainage Engineering, New York, 119(6): 929-46, Nov./Dec. 1993. 
KREYSZIG, E. Advanced engineering mathematics. New York, John Wiley, 1993. 1389 p.

LONGLEY, T.S; GARVIN, P.C; STARK, J.C. Wind drift effects on evapotranspiration under low pressure sprinklers. St. Joseph, ASAE, 1983. 12p. (ASAE Paper, 83-2590)

MAREK, T.H; UNDERSANDER, D.J; EBELING, L.L. An aeral-weighted uniformity coefficient for center pivot system. Transactions of ASAE, St. Joseph, 29(6): 16657, Nov./Dec. 1986.

MARTIN, D.L; YONTS, C.D; STETSON. L.E. Performance of in-canopy sprinkder irrigation devices-field results. St. Joseph, ASAE, 1993. 18 p. (ASAE Paper, 93-2055).

MERRIAM, J.L.; KELLER,J.; ALFARO,J. Irrigation systems evaluation and improvement. Logan, Utah State University, 1973. 221 p.

MICKELSON, R.H \& SCHWEIZER, E.E. Till-plant systems for reducing runoff under low-pressure, center-pivot irrigation. Journal of Soil and Water Conservation, Ankeny, $11:$ 107-11, Mar./Apr. 1987.

MOHAMOUD, Y; McCARTY, T.R; EWING, L.K. Optimum center-pivot irrigation system design with tillage effects. Journal of Irrigation and Drainage Engineering, New York, 118(2): 291-305, Mar./Apr. 1992. 
MOORE, I.D \& LARSON, C.L. An infiltration-runoff model for cultived soils. Transaction of Asae, St. Joseph, 23 . 1460-7, Nov./Dec. 1980.

NELSON IRRIGATION CORPORATION. Nelson 300 series modular sprinkler for pivots. Walla Walla, 1992. 12p.

OLTTTA, A.F.L. Os métodos de irrigação. São Paulo, Nobel, 1987. 267 p.

PRUSKI, F.F; FURUKAWA, C; COSTA, L.M; FONTES, L.E.F; NETTO, A.M. Análise do escoamento superficial, sob condições de irrigação, em solos com e sem cobertura. In: CONGRESSO BRASILEIRO DE ENGENHARIA AGRÍCOLA, 22. Ihéus, SBEA, 1993. Anais . v.4 : p.2352-8.

REZENDE, M; FRANÇA, G.E; ALVES, V.M.C. Considerações técnicas sobre a cultura do milho irrigado. Sete Lagoas, EMBRAPACNPMS, 1990. 24 p. (EMBRAPA/CNPMS. Documentos, 7)

REZENDE, R. Desempenho de um sistema pivô central quanto a uniformidade de aplicação e eficiência de uso da água, abaixo e acima do solo. Piracicaba, 1992. 86p. (Mestrado - Escola Superior de Agricultura "Luiz de Queiroz"/ USP)

ROLLAND, L. Mecanized sprinkler irrigation. Rome, FAO, 1982. 409 p. (FAO Irrigation and Drainage Paper, 35) 
SCALLOPI, E.J \& ALLEN, R.G. Hidraulics of center-pivot laterals. Journal of Irrigation and Drainage Engineering, New York, 119 (3) : 554-67, May./Jun. 1993.

SILVA, W.L.C. Considerações sobre o uso de sprays de baixa pressão em pivô central. ITEM - Irrigação e Tecnologia Moderna, Brasilia, 39: 26 - 7, Dez. 1989.

SKAGGS, R. W.; MILLER, D. E.; BROOKS, R. H. Soil water - properties. In: JENSEN, M. E., ed. Design and operation of farm irrigation systems. St. Joseph, ASAE, 1983. p. 77-136. (ASAE. Monograph 3).

STENER, J.L; KANEMASU, E.T; CLARK, R.N. Spray losses and partitioning of water under a center pivot sprinkler system. Transactions of ASAE, St. Joseph, 26(4): 1128-34, Jul./Aug. 1983.

TEIXEIRA, A. S. Estudo do efeito de diferentes tipos de emissores na performance de um sistema de irrigação por aspersão pivô central. Piracicaba, 1992.89 p. (Mestrado - Escola Superior de Agricultura "Luiz de Queiroz" / USP)

TROUT, T.J; SOJKA, R.E; OKAFOR, L.I. Soil management. In : HOFFMAN, G.J; HOWEL, T.A; SOLOMON, K.N., ed. Management of farm irrigation systems. St. Joseph, ASAE, 1990. p. 873-96.

UNDERSANDER, D.J; MAREK, T.H; CLARK, R.N. Effect of nozzle type on runoff and yield of com and sorghum under center pivot irrigation systems. Irrigation Science, New York, 6: 107-16, Jun. 1985. 
UNITED STATES DEPARTMENT OF AGRICULTURE. Irrigation ; sprinkle irrigation. New York, 1983. 121 p.

VON BERNUTH, R.D \& GILLEY, J.R. Evaluation of center pivot application packages considering droplet induced infiltration reduction. Transactions of ASAE, St. Joseph, 28(6): 1940-6, Nov./Dec. 1985.

WILHELM, W.W; MIELKE, L.N; GILLEY, J.R. Tillage and low-pressure center-pivot irrigation effects on com yeld. Agronomy Journal, Madson, 77: 258-63, Mar./Apr. 1985.

WILMES, G.J; MARTIN, D.L; SUPALLA, R.J. Decision support systems for design of center pivot irrigation systems. St. Joseph, ASAE, 1992. 24 p. (ASAE Paper, MC92-105) 


\section{APÊNDICE 1}

Planilhas dos ensaios de taxa de aplicação e de escoamento durante o ciclo da cultura do milho, utilizando os três emissores e duas lâminas por irrigação :

- Tempo : tempo médio do intervalo

- Aplicação :

- Acumulada :

$\mathrm{ml}$ : volume de aplicação coletado após cada intervalo, resultante da média de quatro calhas e quatro linhas de coletores por calha $\mathrm{mm}$ : volume de aplicação coletado transformado em lâmina F1 : lâmina de aplicação após a utilização da média móvel por uma vez

F2 : lâmina de aplicação após a utilização da média móvel por duas vezes

F3 : lâmina de aplicação após a utilização da média móvel por três vezes

- Taxa : taxa de aplicação em cada intervalo de tempo obtida por diferencią̧ão numérica da coluna F3

- Escoamento :

- Acumulado

$\mathrm{ml}$ : volume de escoamento acumulado após cada intervalo, resultante da média de 4 calhas $\mathrm{mm}$ : volume de escoamento transformado em lâmina

- Taxa : taxa de escoamento em cada intervalo obtida por diferenciação numérica da coluna $\mathbf{m m}$ 
1 - Milho no estádio 1, lâmina de $6 \mathrm{~mm}$, aspersor de impacto, 09/12/93

\begin{tabular}{|c|c|c|c|c|c|c|c|c|c|}
\hline \multirow{3}{*}{$\frac{\text { Tempo }}{\min }$} & \multicolumn{6}{|c|}{ Aplicação } & \multicolumn{3}{|c|}{ Escoamento } \\
\hline & \multicolumn{5}{|c|}{ Acumulada } & \multirow{2}{*}{$\begin{array}{l}\text { Taxa } \\
\mathrm{mm} / \mathrm{h}\end{array}$} & \multicolumn{2}{|c|}{ Acumulado } & \multirow{2}{*}{$\frac{\text { Taxa }}{\mathrm{mm} / \mathrm{h}}$} \\
\hline & $\mathrm{ml}$ & $\mathrm{mm}$ & F1 & F2 & F3 & & $\mathrm{ml}$ & $\mathbf{m m}$ & \\
\hline 0 & 0 & 0.00 & 0.00 & 0.00 & 0.00 & 0.0 & 0 & 0.00 & 0.0 \\
\hline 0.5 & 6.1 & 0.64 & 0.64 & 0.67 & 0.71 & 42.6 & 0 & 0.00 & 0.0 \\
\hline 1.5 & 12.1 & 0.37 & 1.37 & 1.42 & 1.44 & 43.9 & 0 & 0.00 & 0.0 \\
\hline 2.5 & 18.9 & 2.25 & 2.25 & 2.21 & 2.19 & 44.8 & 0 & 0.00 & 0.0 \\
\hline 3.5 & 26.3 & 3.00 & 3.00 & 2.95 & 2.93 & 44.6 & 68 & 0.01 & 0.7 \\
\hline 4.5 & 30.8 & 3.62 & 3.62 & 3.64 & 3.64 & 42.5 & 207 & 0.05 & 2.2 \\
\hline 5.5 & 36.9 & 4.31 & 4.31 & 4.39 & 4.29 & 38.9 & 474 & 0.13 & 5.1 \\
\hline 6.5 & 44.1 & 5.23 & 5.23 & 4.93 & 4.81 & 31.4 & 576 & 0.24 & 6.2 \\
\hline 7.5 & 45.2 & 5.24 & 5.24 & 5.32 & 5.19 & 22.6 & 696 & 0.31 & 4.2 \\
\hline 8.5 & 48.1 & 5.50 & 5.50 & 5.43 & 5.40 & 13.1 & 0 & 0.31 & 0.0 \\
\hline 9.5 & 48.0 & 5.56 & 5.56 & 5.58 & 5.53 & 7.6 & 0 & 0.31 & 0.0 \\
\hline 10.5 & 49.0 & 5.68 & 5.68 & 5.60 & 5.60 & 4.0 & 0 & 0.31 & 0.0 \\
\hline 11.5 & 48.1 & 5.55 & 5.65 & 5.64 & 5.66 & 3.6 & 0 & 0.31 & 0.0 \\
\hline 12.5 & 49.2 & 5.71 & 5.71 & 5.70 & 5.72 & 3.9 & 0 & 0.31 & 0.0 \\
\hline 13.5 & 51.0 & 5.86 & 5.85 & 5.80 & 5.75 & 1.7 & 0 & 0.31 & 0.0 \\
\hline
\end{tabular}

2 - Milho no estádio 1, lâmina de 6 mm, spray giratório ("rotator"), 09/12/93

\begin{tabular}{|c|c|c|c|c|c|c|c|c|c|}
\hline \multirow{3}{*}{$\frac{\text { Tempo }}{\min }$} & \multicolumn{6}{|c|}{ Aplicação } & \multicolumn{3}{|c|}{ Escoamento } \\
\hline & \multicolumn{5}{|c|}{ Acumulada } & \multirow{2}{*}{$\frac{\text { Taxa }}{\mathbf{m m} / \mathbf{h}}$} & \multicolumn{2}{|c|}{ Acumulado } & \multirow{2}{*}{$\frac{\text { Taxa }}{\mathrm{mm} / \mathrm{h}}$} \\
\hline & $\mathrm{ml}$ & $\mathrm{mm}$ & F1 & F2 & F3 & & $\mathrm{ml}$ & $\mathrm{mm}$ & \\
\hline 0.0 & 0.0 & 0.00 & 0.00 & 0.00 & 0.00 & 0.0 & 0 & 0.00 & 0.0 \\
\hline 0.5 & 14.4 & 0.64 & 0.64 & 0.69 & 0.75 & 44.7 & 0 & 0.00 & 0.0 \\
\hline 1.5 & 22.7 & 1.43 & 1.43 & 1.55 & 1.61 & 51.9 & 0 & 0.00 & 0.0 \\
\hline 2.5 & 33.6 & 2.58 & 2.58 & 2.59 & 2.62 & 60.8 & 0 & 0.00 & 0.0 \\
\hline 3.5 & 43.6 & 3.77 & 3.77 & 3.73 & 3.66 & 62.2 & 0 & 0.00 & 0.0 \\
\hline 4.5 & 53.2 & 4.84 & 4.84 & 4.66 & 4.56 & 54.1 & 381 & 0.10 & 5.8 \\
\hline 5.5 & 60.3 & 5.37 & 5.37 & 5.30 & 5.19 & 37.6 & 803 & 0.20 & 6.5 \\
\hline 6.5 & 63.4 & 5.68 & 5.68 & 5.61 & 5.56 & 22.1 & 933 & 0.24 & 2.0 \\
\hline 7.5 & 66.2 & 5.84 & 5.77 & 5.77 & 5.73 & 10.4 & 933 & 0.24 & 0.0 \\
\hline 8.5 & 66.2 & 5.84 & 5.84 & 5.82 & 5.79 & 1.3 & 933 & 0.24 & 0.0 \\
\hline
\end{tabular}


3 - Milho no estádio 1, lâmina de $6 \mathrm{~mm}$, spray fixo, 09/12/93.

\begin{tabular}{|c|c|c|c|c|c|c|c|c|c|}
\hline \multirow{3}{*}{$\begin{array}{l}\text { Tempo } \\
\text { min }\end{array}$} & \multicolumn{6}{|c|}{ Aplicafão } & \multicolumn{3}{|c|}{ Escoamento } \\
\hline & \multicolumn{5}{|c|}{ Acumulada } & \multirow{2}{*}{ Taxa } & \multicolumn{2}{|c|}{ Acumulado } & \multirow{2}{*}{$\frac{\text { Taxa }}{\mathrm{mm} / \mathrm{h}}$} \\
\hline & $\mathrm{ml}$ & $\mathrm{mm}$ & F1 & F2 & F3 & & $\mathrm{ml}$ & $\mathrm{mm}$ & \\
\hline 0.0 & 0.0 & 0.00 & 0.00 & 0.00 & 0.00 & 0.00 & 0 & 0.00 & 0.0 \\
\hline 0.5 & 12.1 & 0.28 & 0.46 & 0.56 & 0.63 & 37.6 & 0 & 0.00 & 0.0 \\
\hline 1.5 & 21.8 & 1.11 & 1.21 & 1.32 & 1.41 & 47.3 & 0 & 0.00 & 0.0 \\
\hline 2.5 & 31.8 & 2.23 & 2.29 & 2.36 & 2.39 & 58.7 & 0 & 0.00 & 0.0 \\
\hline 3.5 & 42.4 & 3.55 & 3.58 & 3.49 & 3.45 & 63.3 & 407 & 0.05 & 3.1 \\
\hline 4.5 & 50.8 & 4.98 & 4.59 & 4.49 & 4.37 & 55.2 & 1460 & 0.19 & 8.0 \\
\hline 5.5 & 53.3 & 5.23 & 5.29 & 5.12 & 5.02 & 39.5 & 2141 & 0.27 & 5.2 \\
\hline 6.5 & 57.6 & 5.65 & 5.49 & 5.47 & 5.39 & 21.7 & 2416 & 0.31 & 2.1 \\
\hline 7.5 & 57.9 & 5.68 & 5.65 & 5.57 & 5.55 & 9.7 & 2416 & 0.31 & 0.0 \\
\hline 8.5 & 58.3 & 5.71 & 5.68 & 5.62 & 5.58 & 1.5 & 2416 & 0.31 & 0.0 \\
\hline
\end{tabular}

4 - Milho no estádio 1, lâmina de $25 \mathrm{~mm}$, aspersor de impacto, 02/12/93.

\begin{tabular}{|c|c|c|c|c|c|c|c|c|c|}
\hline \multirow{3}{*}{$\begin{array}{l}\text { m1- } \\
\text { imp4 } \\
\text { Tempo } \\
\text { min }\end{array}$} & \multicolumn{6}{|c|}{ Aplicação } & \multicolumn{3}{|c|}{ Escoamento } \\
\hline & \multicolumn{5}{|c|}{ Acumulada } & \multirow{2}{*}{$\frac{\text { Taxa }}{\mathrm{mm} / \mathrm{h}}$} & \multicolumn{2}{|c|}{ Acumulado } & \multirow{2}{*}{$\frac{\text { Taxa }}{\mathrm{mm} / \mathrm{h}}$} \\
\hline & $\mathrm{ml}$ & $\mathrm{mm}$ & Fl & F2 & F3 & & $\mathrm{ml}$ & $\mathrm{mm}$ & \\
\hline 0 & 0.0 & 0.00 & 0.00 & 0.00 & 0.00 & 0.0 & 0 & 0.00 & 0.0 \\
\hline 1.5 & 10.0 & 0.85 & 1.53 & 1.77 & 1.89 & 37.8 & 0 & 0.00 & 0.0 \\
\hline 4.5 & 49.6 & 3.73 & 3.78 & 3.91 & 3.98 & 41.8 & 0 & 0.00 & 0.0 \\
\hline 7.5 & 58.5 & 6.76 & 6.41 & 6.27 & 6.18 & 44.0 & 0 & 0.00 & 0.0 \\
\hline 10.5 & 75.8 & 8.76 & 8.63 & 8.37 & 8.26 & 41.5 & 0 & 0.00 & 0.0 \\
\hline 13.5 & 89.8 & 10.36 & 10.08 & 10.13 & 10.06 & 35.9 & 0 & 0.00 & 0.0 \\
\hline 16.5 & 96.4 & 11.13 & 11.68 & 11.66 & 11.78 & 34.4 & 284 & 0.07 & 1.4 \\
\hline 19.5 & 117.6 & 13.58 & 13.21 & 13.53 & 13.62 & 36.9 & 458 & 0.12 & 0.9 \\
\hline 22.5 & 129.3 & 14.93 & 15.70 & 15.67 & 15.77 & 43.0 & 1615 & 0.41 & 5.9 \\
\hline 25.5 & 160.9 & 18.58 & 18.10 & 18.11 & 18.00 & 44.6 & 3593 & 0.91 & 10.1 \\
\hline 28.5 & 180.1 & 20.79 & 20.54 & 20.23 & 20.09 & 41.6 & 6779 & 1.72 & 16.2 \\
\hline 31.5 & 192.6 & 22.25 & 22.05 & 21.91 & 21.73 & 33.0 & 9126 & 2.32 & 11.9 \\
\hline 34.5 & 200.1 & 23.11 & 23.15 & 23.06 & 22.95 & 24.4 & 10325 & 2.63 & 6.1 \\
\hline 37.5 & 208.6 & 24.09 & 23.98 & 23.98 & 23.80 & 16.9 & 10325 & 2.63 & 0.0 \\
\hline 40.5 & 214.1 & 24.73 & 24.54 & 24.45 & 24.35 & 10.9 & 10325 & 2.63 & 0.0 \\
\hline 43.5 & 221.8 & 24.80 & 24.82 & 24.70 & 24.64 & 5.8 & 10325 & 2.63 & 0.0 \\
\hline 46.5 & 215.9 & 24.93 & 24.85 & 24.76 & 24.73 & 1.8 & 10325 & 2.63 & 0.0 \\
\hline 49.5 & 215.3 & 24.91 & 24.92 & 24.82 & 24.82 & 0.0 & 10325 & 2.63 & 0.0 \\
\hline 52.5 & 215.0 & 24.83 & 24.90 & 24.90 & 24.85 & 0.0 & 10325 & 2.63 & 0.0 \\
\hline
\end{tabular}


5 - Milho no estádio 1, lâmina de $25 \mathrm{~mm}$, spray giratório ("rotator"), 02/12/93

\begin{tabular}{|c|c|c|c|c|c|c|c|c|c|}
\hline \multirow{3}{*}{$\frac{\text { Tempo }}{\min }$} & \multicolumn{6}{|c|}{ Aplicação } & \multicolumn{3}{|c|}{ Escoamento } \\
\hline & \multicolumn{5}{|c|}{ Acumulada } & \multirow{2}{*}{$\frac{\text { Taxa }}{\mathrm{mm} / \mathrm{h}}$} & \multicolumn{2}{|c|}{ Acumulado } & \multirow{2}{*}{$\frac{\text { Taxa }}{\mathrm{mm} / \mathrm{h}}$} \\
\hline & $\mathrm{ml}$ & $\mathrm{mm}$ & Fl & F2 & F3 & & $\mathrm{ml}$ & $\mathrm{mm}$ & \\
\hline 0.0 & 0.0 & 0.00 & 0.00 & 0.00 & 0.00 & 0.0 & 0 & 0.00 & 0.0 \\
\hline 1.0 & 19.0 & 2.19 & 1.80 & 2.00 & 2.10 & 63.1 & 0 & 0.00 & 0.0 \\
\hline 3.0 & 46.8 & 5.41 & 4.21 & 4.31 & 4.30 & 65.8 & 0 & 0.00 & 0.0 \\
\hline 5.0 & 62.5 & 7.22 & 6.91 & 6.58 & 6.49 & 65.8 & 50 & 0.01 & 0.4 \\
\hline 7.0 & 70.1 & 8.09 & 8.62 & 8.58 & 8.47 & 59.4 & 133 & 0.03 & 0.6 \\
\hline 9.0 & 91.3 & 10.54 & 10.22 & 10.24 & 10.21 & 52.2 & 525 & 0.13 & 3.0 \\
\hline 11.0 & 104.2 & 12.03 & 11.90 & 11.80 & 11.78 & 47.1 & 1421 & 0.36 & 6.8 \\
\hline 13.0 & 113.6 & 13.12 & 13.27 & 13.29 & 13.31 & 45.9 & 2898 & 0.74 & 11.3 \\
\hline 15.0 & 126.9 & 14.66 & 14.71 & 14.83 & 14.91 & 48.3 & 4201 & 1.07 & 9.9 \\
\hline 17.0 & 141.7 & 16.36 & 16.51 & 16.62 & 16.69 & 53.2 & 6739 & 1.71 & 19.4 \\
\hline 19.0 & 160.3 & 18.51 & 18.64 & 18.61 & 18.64 & 58.6 & 10895 & 2.77 & 31.7 \\
\hline 21.0 & 182.1 & 21.03 & 20.68 & 20.69 & 20.61 & 59.1 & 15558 & 3.96 & 35.6 \\
\hline 23.0 & 194.9 & 22.51 & 22.74 & 22.53 & 22.41 & 40.9 & 19610 & 4.99 & 30.9 \\
\hline 25.0 & 213.7 & 24.68 & 24.16 & 24.02 & 23.77 & 24.7 & 22744 & 5.79 & 23.9 \\
\hline 27.0 & 218.9 & 25.29 & 25.16 & 24.77 & 24.60 & 12.1 & 25053 & 6.37 & 17.6 \\
\hline 29.0 & 220.9 & 25.51 & 25.40 & 25.10 & 25.00 & 1.1 & 25388 & 6.46 & 2.6 \\
\hline 31.0 & 220.9 & 25.51 & 25.00 & 25.15 & 25.15 & 0.0 & 25388 & 6.46 & 0.0 \\
\hline
\end{tabular}


6 - Milho no estádio 1 , lâmina de $25 \mathrm{~mm}$, spray fixo, 02/12/93

\begin{tabular}{|c|c|c|c|c|c|c|c|c|c|}
\hline \multirow{3}{*}{$\frac{\text { Tempo }}{\min }$} & \multicolumn{6}{|c|}{ Aplicação } & \multicolumn{3}{|c|}{ Escoamento } \\
\hline & \multicolumn{5}{|c|}{ Acumulada } & \multirow{2}{*}{$\frac{\text { Taxa }}{\mathrm{mm} / \mathrm{h}}$} & \multicolumn{2}{|c|}{ Acumulado } & \multirow{2}{*}{$\frac{\text { Taxa }}{\mathrm{mm} / \mathrm{h}}$} \\
\hline & $\mathrm{ml}$ & $\mathrm{mm}$ & F1 & $\mathrm{F} 2$ & F3 & & $\mathrm{ml}$ & $\mathrm{mm}$ & \\
\hline 0.0 & 0.0 & 0.00 & 0.00 & 0.00 & 0.00 & 0.0 & 0 & 0.00 & 0.0 \\
\hline 0.75 & 11.0 & 1.85 & 2.15 & 2.01 & 2.06 & 82.5 & 0 & 0.00 & 0.0 \\
\hline 2.25 & 28.4 & 4.60 & 3.89 & 4.18 & 4.15 & 83.4 & 0 & 0.00 & 0.0 \\
\hline 3.75 & 45.1 & 5.21 & 6.50 & 6.25 & 3.32 & 86.7 & 38 & 0.01 & 0.38 \\
\hline 5.25 & 83.8 & 9.68 & 8.37 & 8.52 & 8.41 & 83.8 & 123 & 0.03 & 0.87 \\
\hline 6.75 & 88.6 & 10.23 & 10.68 & 10.46 & 10.44 & 81.2 & 208 & 0.05 & 0.86 \\
\hline 8.25 & 105.2 & 12.15 & 12.32 & 12.34 & 12.25 & 72.5 & 547 & 0.14 & 3.45 \\
\hline 9.75 & 120.4 & 14.60 & 14.01 & 13.96 & 13.88 & 65.3 & 1618 & 0.41 & 10.9 \\
\hline 11.25 & 132.4 & 15.29 & 15.53 & 15.36 & 15.28 & 55.7 & 3090 & 0.79 & 15.0 \\
\hline 12.75 & 144.8 & 16.72 & 16.52 & 16.52 & 16.52 & 49.9 & 4844 & 1.23 & 17.9 \\
\hline 14.25 & 156.0 & 17.56 & 17.49 & 17.70 & 17.83 & 52.4 & 6842 & 1.74 & 20.3 \\
\hline 15.75 & 182.7 & 18.20 & 19.09 & 19.28 & 19.44 & 64.4 & 9401 & 2.39 & 26.0 \\
\hline 17.25 & 186.3 & 21.50 & 21.27 & 21.35 & 21.34 & 75.7 & 12537 & 3.19 & 31.9 \\
\hline 18.75 & 205.1 & 24.12 & 23.68 & 23.38 & 23.22 & 75.5 & 16630 & 4.23 & 41.7 \\
\hline 20.25 & 220.1 & 25.42 & 25.17 & 24.95 & 24.72 & 59.9 & 21597 & 5.50 & 50.6 \\
\hline 21.75 & 225.0 & 25.98 & 25.99 & 25.84 & 25.64 & 36.6 & 27616 & 7.03 & 61.3 \\
\hline 23.25 & 230.0 & 26.56 & 26.37 & 26.12 & 25.79 & 14.0 & 32114 & 8.17 & 45.8 \\
\hline 24.75 & 231.0 & 26.67 & 26.30 & 26.18 & 25.90 & 3.5 & 34122 & 8.68 & 20.4 \\
\hline 26.25 & 230.0 & 26.56 & 26.00 & 26.05 & 26.03 & 0.0 & 34547 & 8.79 & 2.3 \\
\hline
\end{tabular}

7 - Milho no estádio 2, lâmina de $6 \mathrm{~mm}$, aspersor de impacto, 13/01/94.

\begin{tabular}{|c|c|c|c|c|c|c|c|c|c|}
\hline \multirow{3}{*}{$\frac{\text { Tempo }}{\min }$} & \multicolumn{6}{|c|}{ Aplicação } & \multicolumn{3}{|c|}{ Escoamento } \\
\hline & \multicolumn{5}{|c|}{ Acurnulada } & \multirow{2}{*}{$\frac{\operatorname{Taxa}}{\mathrm{mm} / \mathrm{h}}$} & \multicolumn{2}{|c|}{ Acumulado } & \multirow{2}{*}{$\frac{\text { Taxa }}{\mathrm{mm} / \mathrm{h}}$} \\
\hline & $\mathrm{ml}$ & $\mathrm{mm}$ & F1 & F2 & F3 & & $\mathrm{ml}$ & $\mathrm{mm}$ & \\
\hline 0.00 & 0.0 & 0.00 & 0.00 & 0.00 & 0.00 & 0.0 & 0 & 0.00 & 0.0 \\
\hline 0.75 & 4.4 & 0.51 & 0.56 & 0.55 & 0.58 & $\overline{23.1}$ & 0 & 0.00 & 0.0 \\
\hline 2.25 & 10.1 & 1.17 & 1.10 & 1.18 & 1.19 & 24.4 & 0 & 0.00 & 0.0 \\
\hline 3.75 & 14.1 & 1.62 & 1.89 & 1.83 & 1.82 & 25.3 & 0 & 0.00 & 0.0 \\
\hline 5.25 & 25.0 & 2.89 & 2.49 & 2.45 & 2.37 & 21.9 & 0 & 0.00 & 0.0 \\
\hline 6.75 & 25.7 & 2.97 & 2.97 & 2.82 & 2.76 & 15.6 & 201 & 0.05 & 2.1 \\
\hline 8.25 & 26.4 & 3.05 & 3.01 & 2.99 & 2.96 & 8.0 & 324 & 0.08 & 1.3 \\
\hline 9.75 & 26.1 & 3.01 & 3.01 & 3.05 & 3.05 & 3.9 & 324 & 0.08 & 0.0 \\
\hline 11.25 & 25.9 & 2.96 & 3.14 & 3.11 & 3.11 & 2.4 & 324 & 0.08 & 0.0 \\
\hline 12.75 & 29.8 & 3.45 & 3.20 & 3.18 & 3.16 & 1.8 & 324 & 0.08 & 0.0 \\
\hline 14.25 & 27.7 & 3.19 & 3.19 & 3.19 & 3.18 & 0.8 & 324 & 0.08 & 0.0 \\
\hline
\end{tabular}


8 - Milho no estádio 2, lâmina de $6 \mathrm{~mm}$, spray giratónio ("rotator"), 13/01/94

\begin{tabular}{|c|c|c|c|c|c|c|c|c|c|}
\hline \multirow{3}{*}{$\frac{\text { Tempo }}{\min }$} & \multicolumn{6}{|c|}{ Aplicação } & \multicolumn{3}{|c|}{ Escoamento } \\
\hline & \multicolumn{5}{|c|}{ Acumulada } & \multirow{2}{*}{$\frac{\text { Taxa }}{\mathrm{mm} / \mathrm{h}}$} & \multicolumn{2}{|c|}{ Acumulado } & \multirow{2}{*}{$\frac{\text { Taxa }}{\mathrm{mm} / \mathrm{h}}$} \\
\hline & $\mathrm{ml}$ & $\mathrm{mm}$ & $\mathrm{F} 1$ & F2 & $\mathrm{F3}$ & & $\mathrm{ml}$ & $\mathrm{mm}$ & \\
\hline 0.0 & 0.0 & 0.00 & 0.00 & 0.00 & 0.00 & 0.0 & 0 & 0.00 & 0.0 \\
\hline 0.5 & 2.4 & 0.26 & 0.48 & 0.64 & 0.71 & 42.6 & 0 & 0.00 & 0.0 \\
\hline 1.5 & 10.0 & 1.15 & 1.43 & 1.50 & 1.54 & 49.9 & 15 & 0.00 & 0.2 \\
\hline 2.5 & 24.8 & 2.86 & 2.58 & 2.50 & 2.43 & 53.3 & 294 & 0.07 & 4.3 \\
\hline 3.5 & 32.2 & 3.71 & 3.48 & 3.30 & 3.15 & 43.2 & 673 & 0.17 & 5.8 \\
\hline 4.5 & 33.5 & 3.87 & 3.85 & 3.66 & 3.55 & 24.1 & 1404 & 0.36 & 11.2 \\
\hline 5.5 & 34.4 & 3.97 & 3.64 & 3.70 & 3.64 & 5.0 & 1890 & 0.48 & 7.4 \\
\hline 6.5 & 26.7 & 3.08 & 3.61 & 3.65 & 3.62 & 1.2 & 2208 & 0.56 & 4.9 \\
\hline 7.5 & 32.7 & 3.77 & 3.41 & 3.59 & 3.64 & 0.0 & 2208 & 0.56 & 0.0 \\
\hline 8.5 & 29.3 & 3.38 & 3.75 & 3.76 & 3.75 & 0.0 & 2208 & 0.56 & 0.0 \\
\hline
\end{tabular}

9 - Milho no estádio 2, lâmina de 6 mm, spray fixo, 13/01/94.

\begin{tabular}{|c|c|c|c|c|c|c|c|c|c|}
\hline \multirow{3}{*}{$\frac{\text { Tempo }}{\min }$} & \multicolumn{6}{|c|}{ Aplicação } & \multicolumn{3}{|c|}{ Escoamento } \\
\hline & \multicolumn{5}{|c|}{ Acumulada } & \multirow{2}{*}{$\frac{\text { Taxa }}{\mathrm{mm} / \mathrm{h}}$} & \multicolumn{2}{|c|}{ Acumulado } & \multirow{2}{*}{$\frac{\text { Taxa }}{\mathrm{mm} / \mathrm{h}}$} \\
\hline & $\mathrm{ml}$ & $\mathrm{mm}$ & $\overline{F l}$ & $F_{2}$ & $\overline{F 3}$ & & $\mathrm{ml}$ & $\mathrm{mm}$ & \\
\hline 0.0 & 0.0 & 0.00 & 0.00 & 0.00 & 0.00 & 0.0 & $\overline{0}$ & 0.00 & 0.0 \\
\hline 0.5 & 5.6 & 0.65 & 0.70 & 0.79 & 0.84 & 50.2 & 0 & 0.00 & 0.0 \\
\hline 1.5 & 12.6 & 1.45 & 1.68 & 1.72 & 1.76 & 55.7 & 154 & 0.04 & 2.4 \\
\hline 2.5 & 25.4 & 2.94 & 2.77 & 2.78 & 2.71 & 56.8 & 668 & 0.17 & 7.9 \\
\hline 3.5 & 34.0 & 3.93 & 3.90 & 3.63 & 3.52 & 48.7 & 1566 & 0.40 & 13.7 \\
\hline 4.5 & 32.8 & 3.79 & 4.02 & 4.15 & 4.01 & 29.4 & 2301 & 0.59 & 11.2 \\
\hline 5.5 & 33.9 & 3.92 & 4.14 & 4.25 & 4.23 & 13.4 & 2839 & 0.72 & 8.2 \\
\hline 6.5 & 36.9 & 4.26 & 4.32 & 4.30 & 4.34 & 3.4 & 2839 & 0.72 & 0.0 \\
\hline 7.5 & 38.3 & 4.42 & 4.41 & 4.39 & 4.38 & 0.93 & 2839 & 0.72 & 0.0 \\
\hline
\end{tabular}


10 - Milho no estádio 2, lâmina de $25 \mathrm{~mm}$, aspersor de impacto, 06/01/94.

\begin{tabular}{|c|c|c|c|c|c|c|c|c|c|}
\hline \multirow{3}{*}{$\frac{\text { Tempo }}{\min }$} & \multicolumn{6}{|c|}{ Aplicação } & \multicolumn{3}{|c|}{ Escoamento } \\
\hline & \multicolumn{5}{|c|}{ Acumulada } & \multirow{2}{*}{$\frac{\text { Taxa }}{\mathrm{mm} / \mathrm{h}}$} & \multicolumn{2}{|c|}{ Acumulado } & \multirow{2}{*}{$\frac{\text { Taxa }}{\mathrm{mm} / \mathrm{h}}$} \\
\hline & $\mathrm{ml}$ & $\mathrm{mm}$ & $F 1$ & F2 & F3 & & $\mathrm{ml}$ & $\mathrm{mm}$ & \\
\hline 0.0 & 0.0 & 0.00 & 0.00 & 0.00 & 0.00 & 0.0 & 0 & 0.00 & 0.0 \\
\hline 1.5 & 36.7 & 0.91 & 1.05 & 1.10 & 1.17 & 23.5 & 0 & 0.00 & 0.0 \\
\hline 4.5 & 45.3 & 2.25 & 2.24 & 2.42 & 2.52 & 27.0 & 0 & 0.00 & 0.0 \\
\hline 7.5 & 46.8 & 3.58 & 3.97 & 4.05 & 4.16 & 32.6 & 0 & 0.00 & 0.0 \\
\hline 10.5 & 82.1 & 6.10 & 5.95 & 5.99 & 5.95 & 35.9 & 0 & 0.00 & 0.0 \\
\hline 13.5 & 85.3 & 8.20 & 8.05 & 7.81 & 7.72 & 35.4 & 0 & 0.00 & 0.0 \\
\hline 16.5 & 93.4 & 9.85 & 9.42 & 9.36 & 9.26 & 30.9 & 1027 & 0.26 & 5.2 \\
\hline 19.5 & 95.0 & 10.20 & 10.62 & 10.62 & 10.62 & 27.2 & 2578 & 0.66 & 7.9 \\
\hline 22.5 & 116.9 & 11.81 & 11.84 & 11.89 & 11.91 & 25.7 & 5004 & 1.27 & 12.4 \\
\hline 25.5 & 162.4 & 13.50 & 13.20 & 13.21 & 13.22 & 26.3 & 7544 & 1.92 & 12.9 \\
\hline 28.5 & 123.8 & 14.30 & 14.60 & 14.57 & 14.57 & 27.0 & 9595 & 2.44 & 10.4 \\
\hline 31.5 & 138.0 & 16.00 & 15.90 & 15.93 & 15.98 & 28.2 & 10162 & 2.59 & 2.9 \\
\hline 34.5 & 151.0 & 17.40 & 17.29 & 17.44 & 17.51 & 30.6 & 10295 & 2.62 & 0.7 \\
\hline 37.5 & 160.0 & 18.48 & 19.13 & 19.16 & 19.19 & 22.5 & 10311 & 2.62 & 0.1 \\
\hline 40.5 & 186.2 & 21.50 & 21.06 & 20.95 & 20.82 & 32.7 & 10311 & 2.62 & 0.0 \\
\hline 43.5 & 200.9 & 23.20 & 22.66 & 22.34 & 22.15 & 26.6 & 10311 & 2.62 & 0.0 \\
\hline 46.5 & 201.5 & 23.27 & 23.31 & 23.15 & 23.03 & 17.7 & 10311 & 2.62 & 0.0 \\
\hline 49.5 & 202.3 & 23.36 & 23.36 & 23.25 & 23.19 & 11.1 & 10311 & 2.62 & 0.0 \\
\hline 52.5 & 202.4 & 23.38 & 23.37 & 23.27 & 23.24 & 1.5 & 10311 & 2.62 & 0.0 \\
\hline
\end{tabular}


11 - Milho no estádio 2, lâmina de $25 \mathrm{~mm}$, spray giratório ("rotator"), 06/01/94.

\begin{tabular}{|c|c|c|c|c|c|c|c|c|c|}
\hline \multirow{3}{*}{$\frac{\text { Tempo }}{\min }$} & \multicolumn{6}{|c|}{ Aplicação } & \multicolumn{3}{|c|}{ Escoamento } \\
\hline & \multicolumn{5}{|c|}{ Acumulada } & \multirow{2}{*}{$\frac{\text { Taxa }}{\mathrm{mm} / \mathrm{h}}$} & \multicolumn{2}{|c|}{ Acumulado } & \multirow{2}{*}{ Taxa } \\
\hline & $\mathrm{ml}$ & $\mathrm{mm}$ & F1 & $\mathrm{F} 2$ & F3 & & $\mathrm{ml}$ & $\mathrm{mm}$ & \\
\hline 0.0 & 0.0 & 0.00 & 0.00 & 0.00 & 0.00 & 0.0 & 0 & 0.00 & 0.0 \\
\hline 1.0 & 5.0 & 0.58 & 0.90 & 1.18 & 1.34 & 40.2 & 0 & 0.00 & 0.0 \\
\hline 3.0 & 18.5 & 2.14 & 2.63 & 2.84 & 2.97 & 48.9 & 0 & 0.00 & 0.0 \\
\hline 5.0 & 44.9 & 5.19 & 4.97 & 4.89 & 4.91 & 58.1 & 0 & 0.00 & 0.0 \\
\hline 7.0 & 65.7 & 7.59 & 7.06 & 6.99 & 6.87 & 58.9 & 0 & 0.00 & 0.0 \\
\hline 9.0 & 72.8 & 8.40 & 8.95 & 8.73 & 8.61 & 52.3 & 1070 & 0.27 & 8.2 \\
\hline 11.0 & 94.0 & 10.86 & 10.17 & 10.12 & 10.02 & 42.1 & 3714 & 0.94 & 20.2 \\
\hline 13.0 & 94.4 & 11.25 & 11.23 & 11.20 & 11.19 & 35.1 & 6870 & 1.75 & 24.1 \\
\hline 15.0 & 100.4 & 11.59 & 12.20 & 12.23 & 12.24 & 31.6 & 8470 & 2.16 & 12.2 \\
\hline 17.0 & 119.2 & 13.76 & 13.26 & 13.28 & 13.33 & 32.7 & 10945 & 2.79 & 18.9 \\
\hline 19.0 & 125.0 & 14.44 & 14.37 & 14.47 & 14.55 & 36.6 & 14293 & 3.64 & 25.6 \\
\hline 21.0 & 129.0 & 14.90 & 15.79 & 15.89 & 15.95 & 42.1 & 17387 & 4.42 & 23.6 \\
\hline 23.0 & 156.2 & 18.04 & 17.52 & 17.48 & 17.52 & 46.9 & 20493 & 5.21 & 23.7 \\
\hline 25.0 & 170.1 & 19.64 & 19.14 & 19.17 & 19.12 & 48.1 & 23563 & 6.00 & 23.4 \\
\hline 27.0 & 181.0 & 19.75 & 20.84 & 20.70 & 20.81 & 50.7 & 24931 & 6.34 & 10.4 \\
\hline 29.0 & 200.4 & 23.14 & 22.11 & 22.55 & 22.36 & 26.7 & 25145 & 6.40 & 1.6 \\
\hline 31.0 & 203.0 & 23.44 & 23.41 & 23.38 & 23.35 & 2.2 & 24145 & 6.40 & 0.0 \\
\hline
\end{tabular}


12 - Milho no estádio 2, lâmina de 25 mm, spray fixo, 06/01/94.

\begin{tabular}{|c|c|c|c|c|c|c|c|c|c|}
\hline \multirow{3}{*}{$\frac{\text { Tempo }}{\min }$} & \multicolumn{6}{|c|}{ Aplicação } & \multicolumn{3}{|c|}{ Escoamento } \\
\hline & \multicolumn{5}{|c|}{ Acumulada } & \multirow{2}{*}{$\frac{\mathrm{Taxa}}{\mathrm{mm} / \mathrm{h}}$} & \multicolumn{2}{|c|}{ Acumulado } & \multirow{2}{*}{$\frac{\text { Taxa }}{\mathrm{mm} / \mathrm{h}}$} \\
\hline & $\mathrm{ml}$ & $\mathrm{mm}$ & F1 & $F 2$ & F3 & & $\mathrm{ml}$ & $\mathrm{mm}$ & \\
\hline 0.00 & 0.0 & 0.00 & 0.00 & 0.00 & 0.00 & 0.0 & 0 & 0.00 & 0.0 \\
\hline 0.75 & 18.3 & 1.88 & 1.72 & 1.80 & 1.87 & 74.7 & 0 & 0.00 & 0.0 \\
\hline 2.25 & 37.2 & 3.29 & 3.67 & 3.80 & 3.86 & 79.9 & 0 & 0.00 & 0.0 \\
\hline 3.75 & 59.7 & 5.85 & 6.01 & 5.99 & 6.00 & 85.5 & 454 & 0.09 & 3.5 \\
\hline 5.25 & 76.9 & 8.88 & 8.29 & 8.21 & 8.12 & 84.8 & 1537 & 0.29 & 8.3 \\
\hline 6.75 & 96.7 & 10.15 & 10.34 & 10.16 & 10.05 & 77.3 & 3994 & 0.76 & 18.8 \\
\hline 8.25 & 103.9 & 12.00 & 11.85 & 11.79 & 11.67 & 64.6 & 8020 & 1.53 & 30.8 \\
\hline 9.75 & 116.0 & 13.40 & 13.17 & 13.06 & 12.98 & 52.5 & 12783 & 2.44 & 36.4 \\
\hline 11.25 & 122.1 & 14.10 & 14.17 & 14.10 & 14.04 & 42.1 & 17771 & 3.39 & 38.1 \\
\hline 12.75 & 129.9 & 15.00 & 14.97 & 14.95 & 14.60 & 34.6 & 24738 & 4.72 & 53.2 \\
\hline 14.25 & 136.8 & 15.80 & 14.70 & 15.66 & 15.76 & 34.2 & 32959 & 6.29 & 62.8 \\
\hline 15.75 & 141.1 & 16.30 & 16.30 & 16.66 & 16.79 & 41.3 & 41497 & 7.92 & 65.2 \\
\hline 17.25 & 145.5 & 16.80 & 18.00 & 18.04 & 18.24 & 58.1 & 49883 & 9.52 & 64.0 \\
\hline 18.75 & 180.9 & 20.89 & 19.83 & 20.01 & 19.97 & 69.3 & 57480 & 10.97 & 58.0 \\
\hline 20.25 & 188.7 & 21.79 & 22.21 & 21.86 & 21.82 & 73.9 & 61338 & 11.71 & 29.5 \\
\hline 21.75 & 207.3 & 23.94 & 23.54 & 23.58 & 23.78 & 36.5 & 62497 & 11.93 & 8.9 \\
\hline 23.25 & 215.6 & 24.90 & 24.88 & 24.86 & 24.85 & 2.4 & 62559 & 11.94 & 0.5 \\
\hline 24.75 & 216.1 & 24.93 & 24.90 & 24.89 & 24.87 & 0.0 & 62559 & 11.94 & 0.0 \\
\hline
\end{tabular}


13 - Milho no estádio 3, lâmina de $6 \mathrm{~mm}$, aspersor de impacto, 03/02/94.

\begin{tabular}{|c|c|c|c|c|c|c|c|c|c|}
\hline \multirow{3}{*}{$\frac{\text { Tempo }}{\min }$} & \multicolumn{6}{|c|}{ Aplicação } & \multicolumn{3}{|c|}{ Escoamento } \\
\hline & \multicolumn{5}{|c|}{ Acumulada } & \multirow{2}{*}{$\frac{\text { Taxa }}{\mathrm{mm} / \mathrm{h}}$} & \multicolumn{2}{|c|}{ Acumulado } & \multirow{2}{*}{$\frac{\text { Taxa }}{\mathrm{mm} / \mathrm{h}}$} \\
\hline & $\mathrm{ml}$ & $\mathrm{mm}$ & Fl & F2 & F3 & & $\mathrm{ml}$ & $\mathrm{mm}$ & \\
\hline 0.00 & 0.0 & 0.00 & 0.00 & 0.00 & 0.00 & 0.0 & 0 & 0.00 & 0.0 \\
\hline 0.75 & 1.3 & 0.15 & 0.30 & 0.40 & 0.46 & 18.6 & 0 & 0.00 & 0.0 \\
\hline 2.25 & 6.5 & 0.75 & 0.91 & 0.99 & 1.02 & 22.3 & 0 & 0.00 & 0.0 \\
\hline 3.75 & 15.8 & 1.82 & 1.75 & 1.67 & 1.64 & 24.9 & 53 & 0.01 & 0.5 \\
\hline 5.25 & 21.9 & 2.54 & 2.35 & 2.27 & 2.21 & 22.5 & 89 & 0.02 & 0.4 \\
\hline 6.75 & 23.5 & 2.69 & 2.71 & 2.68 & 2.66 & 18.0 & 420 & 0.10 & 3.2 \\
\hline 8.25 & 25.1 & 2.90 & 2.99 & 3.02 & 3.00 & 13.6 & 523 & 0.13 & 1.0 \\
\hline 9.75 & 30.5 & 3.52 & 3.37 & 3.29 & 3.24 & 9.9 & 523 & 0.13 & 0.0 \\
\hline 11.25 & 31.9 & 3.69 & 3.50 & 3.42 & 3.35 & 4.4 & 523 & 0.13 & 0.0 \\
\hline 12.75 & 28.6 & 3.30 & 3.38 & 3.38 & 3.39 & 1.5 & 523 & 0.13 & 0.0 \\
\hline 14.25 & 28.3 & 3.27 & 3.32 & 3.36 & 3.38 & 0.0 & 523 & 0.13 & 0.0 \\
\hline
\end{tabular}

14 - Milho no estádio 3, lâmina de $6 \mathrm{~mm}$, spray giratório ("rotator"), 03/02/94.

\begin{tabular}{|c|c|c|c|c|c|c|c|c|c|}
\hline \multirow{3}{*}{$\frac{\text { Tempo }}{\min }$} & \multicolumn{6}{|c|}{ Aplicação } & \multicolumn{3}{|c|}{ Escoamento } \\
\hline & \multicolumn{5}{|c|}{ Acumulada } & \multirow{2}{*}{$\frac{\text { Taxa }}{\mathrm{mm} / \mathrm{h}}$} & \multicolumn{2}{|c|}{ Acumulado } & \multirow{2}{*}{$\frac{\text { Taxa }}{\mathrm{mm} / \mathrm{h}}$} \\
\hline & $\mathrm{ml}$ & $\mathrm{mm}$ & F1 & F2 & F3 & & $\mathrm{ml}$ & $\mathrm{mm}$ & \\
\hline 0.0 & 0.0 & 0.00 & 0.00 & 0.00 & 0.00 & 0.0 & 0 & 0.00 & 0.0 \\
\hline 0.5 & 4.1 & 0.47 & 0.63 & 0.64 & 0.66 & 39.7 & 0 & 0.00 & 0.0 \\
\hline 1.5 & 12.3 & 1.42 & 1.28 & 1.35 & 1.34 & 40.8 & 0 & 0.00 & 0.0 \\
\hline 2.5 & 17.0 & 1.96 & 2.13 & 2.04 & 2.03 & 41.2 & 39 & 0.01 & 0.3 \\
\hline 3.5 & 26.0 & 3.01 & 2.70 & 2.70 & 2.65 & 37.0 & 157 & 0.04 & 2.1 \\
\hline 4.5 & 27.2 & 3.14 & 3.27 & 3.20 & 3.17 & 31.3 & 393 & 0.10 & 3.6 \\
\hline 5.5 & 31.7 & 3.66 & 3.63 & 3.60 & 3.55 & 22.9 & 511 & 0.13 & 1.8 \\
\hline 6.5 & 35.4 & 4.09 & 3.91 & 3.84 & 3.78 & 14.0 & 589 & 0.15 & 1.2 \\
\hline 7.5 & 34.6 & 3.99 & 3.97 & 3.95 & 3.93 & 1.1 & 589 & 0.15 & 0.0 \\
\hline
\end{tabular}


15 - Milho no estádio 3, lâmina de $6 \mathrm{~mm}$, spray fixo, 03/02/94.

\begin{tabular}{|c|c|c|c|c|c|c|c|c|c|}
\hline & \multicolumn{5}{|c|}{ Aplicação } & \multicolumn{3}{c|}{ Escoamento } \\
\cline { 2 - 11 } & \multicolumn{5}{|c|}{ Acumulada } & & & \\
Tempo & \multicolumn{5}{|c|}{ Taxa } & \multicolumn{2}{|c|}{ Acumulado } & Taxa \\
\hline $\min$ & $\mathrm{ml}$ & $\mathrm{mm}$ & $\mathrm{F} 1$ & $\mathrm{~F} 2$ & $\mathrm{~F}$ & $\mathrm{~mm} / \mathrm{h}$ & $\mathrm{ml}$ & $\mathrm{mm}$ & $\mathrm{mm} / \mathrm{h}$ \\
\hline 0.0 & 0.0 & 0.00 & 0.00 & 0.00 & 0.00 & 0.0 & 0 & 0.00 & 0.0 \\
\hline 0.5 & 2.3 & 0.27 & 0.60 & 0.71 & 0.82 & 49.0 & 0 & 0.00 & 0.0 \\
\hline 1.5 & 13.2 & 1.52 & 1.54 & 1.74 & 1.78 & 57.2 & 8 & 0.00 & 0.1 \\
\hline 2.5 & 24.6 & 2.84 & 3.07 & 2.88 & 2.85 & 64.4 & 118 & 0.03 & 1.7 \\
\hline 3.5 & 31.8 & 3.37 & 4.02 & 3.94 & 3.73 & 53.0 & 314 & 0.08 & 3.0 \\
\hline 4.5 & 37.9 & 4.37 & 4.72 & 4.39 & 4.29 & 33.3 & 550 & 0.14 & 3.6 \\
\hline 5.5 & 38.5 & 4.45 & 4.42 & 4.44 & 4.36 & 10.6 & 825 & 0.21 & 4.2 \\
\hline 6.5 & 37.1 & 4.28 & 4.48 & 4.46 & 4.42 & 2.3 & 943 & 0.24 & 1.8 \\
\hline 7.5 & 38.7 & 4.47 & 4.45 & 4.45 & 4.44 & 0.0 & 1022 & 0.26 & 1.2 \\
\hline 8.5 & 38.7 & 4.47 & 4.45 & 4.45 & 4.44 & 0.0 & 1022 & 0.26 & 0.0 \\
\hline
\end{tabular}




\section{APÊNDICE 2}

Planilhas dos dados de taxa de aplicação e de escoamento dos testes de infiltração

- Tempo : tempo médio do intervalo

- Aplicação :

- Acumulada :

$\mathrm{ml}$ : volume de aplicação coletado após cada intervalo, resultante da média de 6 calhas

e quatro linhas de coletores por calha

$\mathrm{mm}$ : volume de aplicação coletado transformado em lâmina

F1 : lâmina de aplicação após a utilização da média móvel por uma vez

F2 : lâmina de aplicação após a utilização da média móvel por duas vezes

F3 : lâmina de aplicação após a utilização da média móvel por três vezes

- Taxa : taxa de aplicação em cada intervalo de tempo obtida por diferenciação numérica da coluna F3

- Escoamento :

- Acumulado

$\mathrm{ml}$ : volume de escoamento acumulado após cada intervalo, resultante da média de 6 calhas

$\mathrm{mm}$ : volume de escoamento transformado em lâmina

F1 : lâmina de escoamento após a utilização da média móvel por uma vez

F2 : lâmina de escoamento após a utilização da média móvel por duas vezes

F3 : lâmina de escoamento após a utilização da média móvel por três vezes

- Taxa : taxa de escoamento em cada intervalo obtida por diferenciação numérica da coluna F3

- Taxa de infiltração : diferença entre a taxa de aplicação e de escoamento em cada intervalo de tempo 


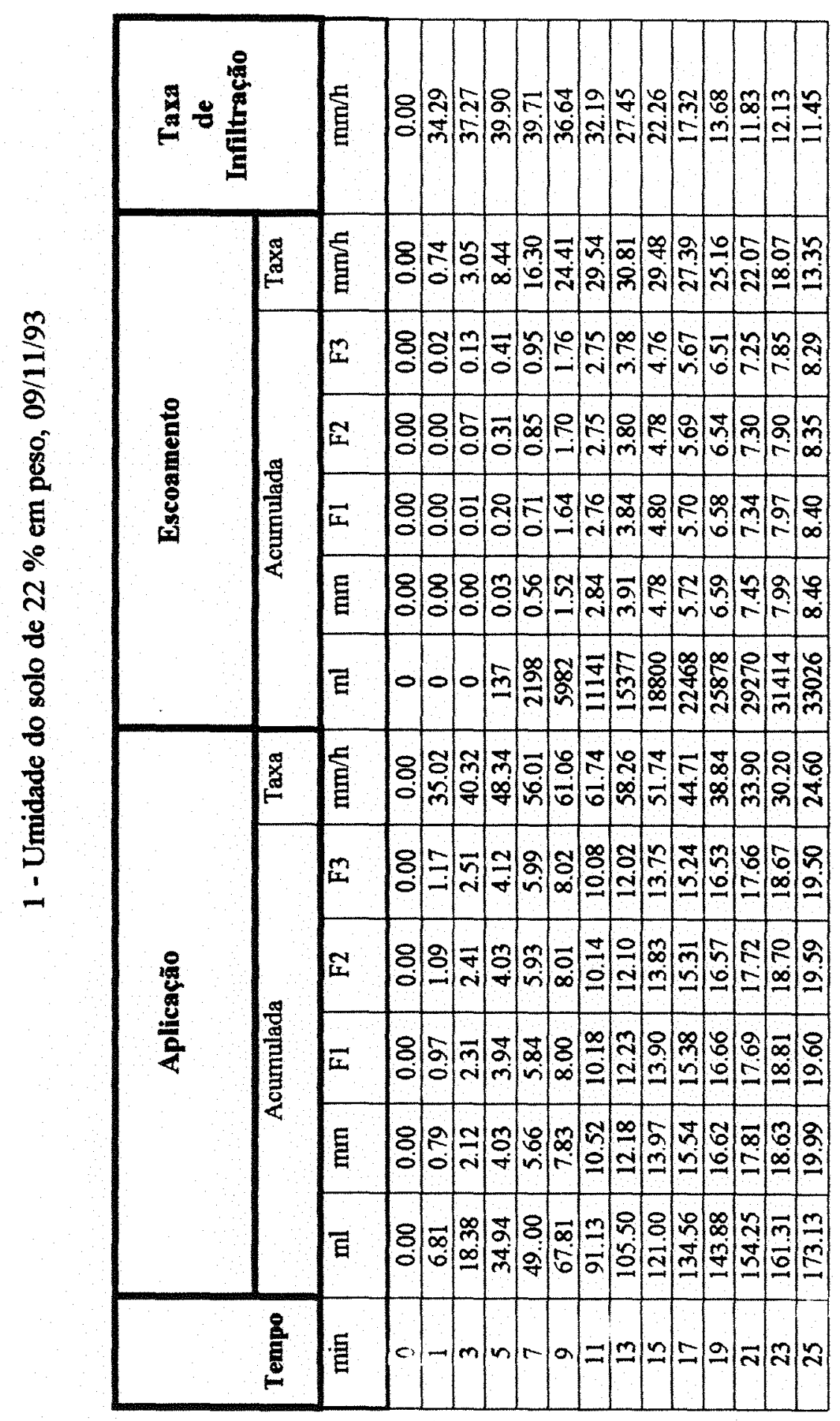




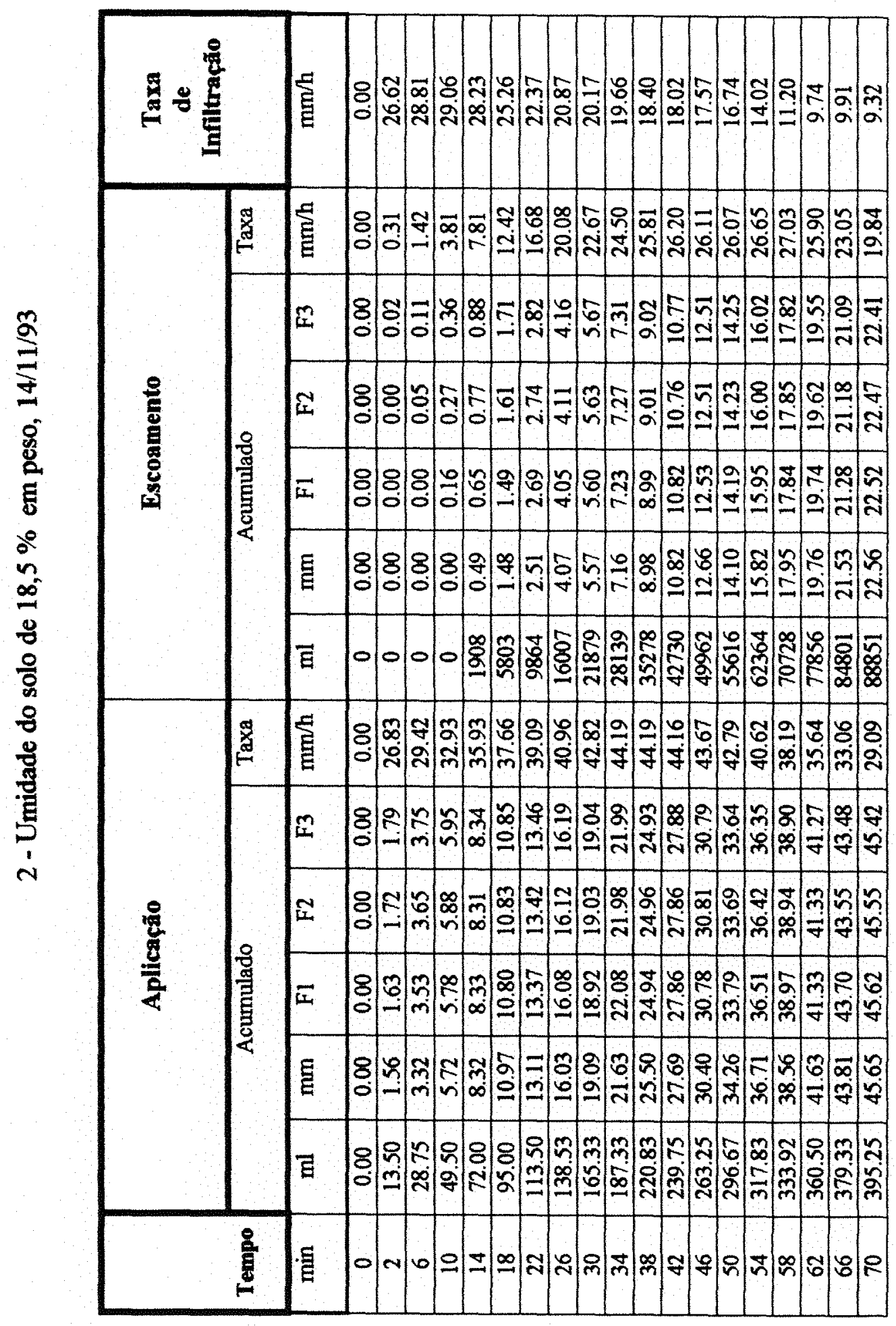

